\title{
Assessment of Appalachian Basin Oil and Gas Resources: Devonian Gas Shales of the Devonian Shale-Middle and Upper Paleozoic Total Petroleum System
}

By Robert C. Milici and Christopher S. Swezey

Chapter G.9 of

Coal and Petroleum Resources in the Appalachian Basin:

Distribution, Geologic Framework, and Geochemical Character

Edited by Leslie F. Ruppert and Robert T. Ryder

Professional Paper 1708 
Suggested citation:

Milici, R.C., and Swezey, C.S., 2014, Assessment of Appalachian basin oil and gas resources; Devonian gas shales of the Devonian Shale-Middle and Upper Paleozoic Total Petroleum System, chap. G.9 of Ruppert, L.F., and Ryder, R.T., eds., Coal and petroleum resources in the Appalachian basin; Distribution, geologic framework, and geochemical character: U.S. Geological Survey Professional Paper 1708, 81 p., http://dx.doi.org/10.3133/pp1708G.9. 


\section{Contents}



\section{Figures}

[Figures follow References Cited]

1. Map showing the location of the Appalachian Basin Petroleum Province and the location of the Drake oil well..

2. Map showing the extent of the the Devonian Shale-Middle and Upper Paleozoic Total Petroleum System within the Appalachian Basin Petroleum Province

3. Chart showing the generalized stratigraphy of the Appalachian Basin Petroleum Province and total petroleum system data...

4. Chart showing generalized stratigraphic nomenclature for Lower Devonian through Upper Mississippian strata in the northern part of Appalachian Basin Petroleum Province.

5. Map showing the extent of the Devonian Shale-Middle and Upper Paleozoic Total Petroleum System and thickness of Devonian siliciclastic strata in the Appalachian Basin Petroleum Province.

6. Map showing the extent of Devonian strata in the Appalachian Basin Petroleum Province and the location of geologic cross section $A-A^{\prime}$. 
7. Geologic cross section of Devonian strata from New York to Alabama showing generalized facies of Harper.

8. Generalized cross section of Devonian siliciclastic strata across eastern Ohio and western Pennsylvania.

9. Chart showing the correlation of Devonian and Mississippian black shale units and some related strata in the Appalachian Basin Petroleum Province

10. Chart showing stratigraphic nomenclature for the Upper Devonian through Upper Mississippian strata in the eastern part of the Appalachian Basin Petroleum Province.

11. Map of the Appalachian Basin Petroleum Province, illustrating the extent of the Devonian and Lower Mississippian shale, the extent of oil in Devonian shale, and vitrinite-reflectance contours

12. Map showing the four Devonian gas shale assessment units and the distribution of oil and gas wells within the assessment units.

13. Map showing the extent of the Devonian Marcellus Shale and Millboro Shale, and the extent of Devonian shale beyond the area of the Marcellus and Millboro Shales

14. Chart showing petroleum system events for the Devonian Shale-Middle and Upper Paleozoic Total Petroleum System in the Appalachian Basin Petroleum Province.

15. Map of Devonian shale assessment units, showing net thickness of black shale and areas of closely spaced oil and gas wells.

16. Map showing the extent of the Greater Big Sandy Assessment Unit, thermal maturity isolines, and net thickness of black shale

17. Stratigraphic cross section $D-D^{\prime}$, showing Devonian and Lower Mississippian strata across the Greater Big Sandy Assessment Unit in eastern Kentucky and western West Virginia.

18. Stratigraphic cross section $C-C^{\prime}$, showing Devonian and Lower Mississippian strata across the Greater Big Sandy Assessment Unit in southern Ohio, eastern Kentucky, and West Virginia

19. Map showing the qualitative assessment of gas recoverability from Devonian shale within each gas play of the Appalachian Basin Petroleum Province.

20. Map showing the relation of the Greater Big Sandy Assessment Unit to regional geologic structure.

21. Map showing the locations of gas wells and named gas fields producing from Devonian shale in the Greater Big Sandy Assessment Unit.

22. Map showing the geological settings and partitioned areas in the Greater Big Sandy Assessment Unit

23. Graph showing the distribution of estimated ultimate recovery values per well for wells in Devonian shale of eastern Kentucky.

24. Map showing the outline of the Northwestern Ohio Shale Assessment Unit, the location of the Amerada No.1 Ullman well, and the locations of cross sections $E-E^{\prime}$ and $F-F^{\prime}$....

25. Cross section $E-E^{\prime}$, showing the Devonian and Lower Mississippian strata across western Pennsylvania and northeastern Ohio

26. Cross section $F-F^{\prime}$, showing the Devonian and Lower Mississippian strata across western West Virginia and east-central Ohio

27. Map showing the relation of the Northwestern Ohio Shale Assessment Unit to geologic structure. 
28. Map showing named fields in the Northwestern Ohio Shale Assessment Unit..............60

29. Graph showing a burial and hydrocarbon generation plot for the Amerada No. 1 Ullman well in Noble County, Ohio.

30. Map showing the geological settings and partitioned areas in the Northwestern Ohio Shale Assessment Unit

31. Graph showing the distribution of estimated ultimate recovery values per well for wells in the Northwestern Ohio Shale Assessment Unit

32. Map showing the extent and thickness of Devonian strata in the Appalachian Basin Petroleum Province and the Devonian Siltstone and Shale Assessment Unit....65

33. Map showing relation of the Devonian Siltstone and Shale Assessment Unit to geologic structure

34. Map showing locations of named fields in the Devonian Siltstone and Shale Assessment Unit and the Marcellus Shale Assessment Unit

35. Map showing estimated gas-in-place resources for the Huron Member of the Ohio Shale, the Rhinestreet Shale Member of the West Falls Formation, and the Marcellus Shale

36. Graph showing the distribution of estimated ultimate recovery values per well for wells for the Devonian Siltstone and Shale Assessment Unit..

37. Isopach map of the Marcellus Shale

\section{Tables}

[Tables follow figures]

1. Characterization of assessment units for the U.S. Geological Survey 2002 assessment of undiscovered oil and gas resources in the Appalachian Basin Petroleum Province (summarized by Milici and others, 2003).

2. Estimates of gas-in-place (GIP) resources in plays identified in figure 19 from Charpentier and others, 1993, as allocated to the Devonian shale assessment units in the Appalachian Basin Petroleum Province

3. Devonian shale geochemistry data from the Appalachian Basin Petroleum

Province (compiled from Streib, 1981)

4. Summary of total organic carbon (TOC) content of samples from the Devonian Marcellus Shale and the Rhinestreet Shale Member of the West Falls Formation (compiled from Weary and others, 2000; Repetski and others, 2002, 2005) 


\section{Conversion Factors}

\begin{tabular}{|c|c|c|}
\hline Multiply & By & To obtain \\
\hline \multicolumn{3}{|c|}{ Length } \\
\hline inch (in.) & 2.54 & centimeter $(\mathrm{cm})$ \\
\hline foot $(\mathrm{ft})$ & 0.3048 & meter $(\mathrm{m})$ \\
\hline mile (mi) & 1.609 & kilometer (km) \\
\hline \multicolumn{3}{|c|}{ Area } \\
\hline square inch $\left(\mathrm{in}^{2}\right)$ & 6.452 & square centimeter $\left(\mathrm{cm}^{2}\right)$ \\
\hline square mile $\left(\mathrm{mi}^{2}\right)$ & 2.590 & square kilometer $\left(\mathrm{km}^{2}\right)$ \\
\hline \multicolumn{3}{|c|}{ Volume } \\
\hline barrel (bbl; 42 U.S. gallons) & 0.1590 & cubic meter $\left(\mathrm{m}^{3}\right)$ \\
\hline cubic foot $\left(\mathrm{ft}^{3}\right)$ & 0.02832 & cubic meter $\left(\mathrm{m}^{3}\right)$ \\
\hline \multicolumn{3}{|c|}{ Mass } \\
\hline pound, avoirdupois (lb) & 0.4536 & kilogram (kg) \\
\hline \multicolumn{3}{|c|}{ Pressure } \\
\hline pound per square inch $\left(\mathrm{lb} / \mathrm{in}^{2}\right)$ & 6.895 & kilopascal $(\mathrm{kPa})$ \\
\hline
\end{tabular}

Horizontal coordinate information is referenced to the North American Datum of 1927. 


\title{
Assessment of Appalachian Basin Oil and Gas Resources: Devonian Gas Shales of the Devonian Shale-Middle and Upper Paleozoic Total Petroleum System
}

\author{
By Robert C. Milici' and Christopher S. Swezey ${ }^{1}$
}

\section{Abstract}

This report presents the results of a U.S. Geological Survey (USGS) assessment of the technically recoverable undiscovered natural gas resources in Devonian shale in the Appalachian Basin Petroleum Province of the eastern United States. These results are part of the USGS assessment in 2002 of the technically recoverable undiscovered oil and gas resources of the province. This report does not use the results of a 2011 USGS assessment of the Devonian Marcellus Shale because the area considered in the 2011 assessment is much greater than the area of the Marcellus Shale described in this report. The USGS assessment in 2002 was based on the identification of six total petroleum systems, which include strata that range in age from Cambrian to Pennsylvanian. The Devonian gas shales described in this report are within the Devonian Shale-Middle and Upper Paleozoic Total Petroleum System, which extends generally from New York to Tennessee. This total petroleum system is divided into ten assessment units (plays), four of which are classified as conventional and six as continuous. The Devonian shales described in this report make up four of these continuous assessment units. The assessment results are reported as fully risked fractiles (F95, F50, F5, and the mean); the fractiles indicate the probability of recovery of the assessment amount. The products reported are oil, gas, and natural gas liquids. The mean estimates for technically recoverable undiscovered hydrocarbons in the four gas shale assessment units are 12,195.53 billion cubic feet (12.20 trillion cubic feet) of gas and 158.91 million barrels of natural gas liquids.

\section{Introduction}

This report is part of the U.S. Geological Survey (USGS) Appalachian basin coal and petroleum resources framework study. The study area includes resources in strata traditionally assigned to both the Appalachian basin and the Black

${ }^{1}$ U.S. Geological Survey, Reston, Va.
Warrior basin. For energy assessment purposes, however, the Appalachian and Black Warrior basins are merged because the resources can be continuous from one basin to the other. The boundary of the structural Appalachian basin differs from that of the Appalachian Basin Petroleum Province (067), which was defined for the USGS 1995 National Oil and Gas Assessment (Gautier and others, 1998); in that assessment, the Black Warrior Basin Province (065) also was separately defined and assessed.

The 2002 U.S. Geological Survey assessment of the technically recoverable undiscovered oil and gas resources in the Appalachian Basin Petroleum Province of the United States identified six total petroleum systems (Milici and others, 2003). One of these petroleum systems is the Devonian ShaleMiddle and Upper Paleozoic Total Petroleum System (TPS), which consists of Devonian shale petroleum source rocks and various reservoir intervals in Middle and Upper Paleozoic strata. The reservoir intervals of this TPS were assigned to 10 assessment units, four of which are Devonian gas shale units. This report presents a summary of these four gas shale units, using the 2002 assessment results reported by Milici and others (2003) and additional descriptions and interpretations reported by Milici and Swezey (2006). This report does not use the results of a 2011 USGS assessment of the Devonian Marcellus Shale (Coleman and others, 2011) because the area considered in the 2011 assessment is much greater than the area of the Marcellus Shale Assessment Unit (AU) described in this report.

The first well drilled specifically for natural gas in the United States was operated by William A. Hart in 1821, in the village of Fredonia, Chautauqua County, New York (Weeks, 1886). The well was drilled into the Devonian Dunkirk Shale Member of the Perrysburg Formation, produced gas from depths of 30 to 70 feet (ft), and supplied gas to Fredonia for several years (de Witt, 1997). The modern petroleum industry had its beginnings in the Appalachian Basin Petroleum Province on August 27, 1859, when Colonel Edwin L. Drake (Seneca Oil Company) produced oil from a well drilled to a depth of $69.5 \mathrm{ft}$ on Oil Creek, near Titusville in northwestern Pennsylvania (fig. 1). The well was located near surface seeps where oil had been collected and used locally, first by Native 
Americans and then by early settlers. The production was from a relatively thin bed of sandstone in the Upper Devonian Riceville Formation (Carter and Flaherty, 2011). The well reportedly produced at least 10 barrels of oil per day for a year and was the first oil produced commercially from a well drilled in the United States. The success of the well ignited an "industrial explosion" that spread rapidly throughout the region and into other areas of the country. A brief history of the Drake well and oil development in the Titusville area was compiled by the U.S. Department of the Interior (1976). Drake did not realize it at the time, but he had discovered the Devonian Shale-Middle and Upper Paleozoic Total Petroleum System, which is the foremost petroleum system in the Appalachian Basin Petroleum Province (figs. 2, 3).

The Devonian Shale-Middle and Upper Paleozoic TPS contains some of the more productive petroleum source rocks and reservoirs in the Appalachian Basin Petroleum Province (fig. 2). The regional stratigraphy and geologic framework of the Devonian System in the Appalachian Basin Petroleum Province and depositional models for these strata have been described by numerous writers (for example, Oliver and others, 1967, 1971; Piotrowski and Krajewski, 1977; Piotrowski and Harper, 1979; Ettensohn, 1985a,b; Lundegard and others, 1985; Sevon, 1985; Bjerstedt, 1986; Dennison and others, 1986, 1996; Kammer and Bjerstedt, 1986; Bjerstedt and Kammer, 1988; Boswell and Donaldson, 1988; Boswell and Jewell, 1988; Denkler and Harris, 1988; Hasson and Dennison, 1988; Milici and de Witt, 1988; Woodrow and others, 1988; de Witt and others, 1993; Boswell, 1996; Boswell, Heim, and others, 1996; Boswell, Thomas, and others, 1996; Donaldson and others, 1996; Matchen and Vargo, 1996; Milici, 1996a,c; Tomastik, 1996; Van Tyne, 1996; Vargo and Matchen, 1996; Faill, 1997; Harper, 1999; Swezey, 2002; Filer, 2003; Ettensohn, 2008).

\section{Stratigraphy}

The Devonian through Lower Mississippian strata in the Appalachian Basin Petroleum Province may be divided into the following two groups: (1) Lower Devonian predominantly carbonate strata; and (2) Middle Devonian through Lower Mississippian predominantly siliciclastic strata (figs. 3, 4). Most of the Lower Devonian carbonate strata (for example, the Helderberg Group) are interpreted as pre-orogenic stableshelf sediments, whereas most of the Middle Devonian through Lower Mississippian siliciclastic strata are interpreted as syn- to post-orogenic turbidite and deltaic sediments that accumulated in a foreland basin in association with the Acadian orogeny.

A regional unconformity is present throughout the basin immediately below the Upper Devonian Berea Sandstone and equivalent strata. This regional unconformity is referred to as the Kaskaskia I-Kaskaskia II unconformity (Sloss, 1988; Swezey, 2002). In some older publications, some Middle
Devonian through Upper Devonian siliciclastic strata (for example, the Needmore Shale through Hampshire Formation; fig. 4) below the Kaskaskia I-Kaskaskia II unconformity are informally referred to as the "Catskill delta" and some Upper Devonian through Lower Mississippian siliciclastic strata (for example, the Price Formation, Rockwell Formation, and Purslane Sandstone; fig. 4) above the Kaskaskia I-Kaskaskia II unconformity are sometimes informally referred to as the "Price-Rockwell delta." The Lower Mississippian siliciclastic strata are overlain by Mississippian carbonate strata (for example, the Greenbrier Limestone; fig. 4) that are interpreted as stable-shelf sediments that accumulated before the Alleghanian orogeny began.

\section{Middle Devonian Through Upper Devonian Siliciclastic Strata Below the Kaskaskia I- Kaskaskia II Unconformity}

The Middle Devonian through Upper Devonian siliciclastic strata below the Kaskaskia I-Kaskaskia II unconformity consist of a coarsening-upward sequence that is thickest (up to $12,000 \mathrm{ft}$ ) in eastern Pennsylvania (fig. 5). The strata thin westward across the basin into central Ohio, where they are about $400 \mathrm{ft}$ thick, and southwestward to Tennessee, where Middle Devonian strata are absent and the Upper Devonian to Lower Mississippian strata are approximately $8 \mathrm{ft}$ thick (Hayes, 1891). The geographic extent of the Devonian strata and a generalized cross section along the depositional strike of these strata are shown in figures 6 and 7 (Oliver and others, 1967; de Witt and others, 1975).

From west to east, the Middle to Upper Devonian siliciclastic strata below the Kaskaskia I-Kaskaskia II unconformity consist of several distinct lithologic units that extend widely across the basin (Boswell and Donaldson, 1988). Black mudstone (interpreted as distal marine deposits) in the western part of the basin grades laterally eastward and vertically into gray and green, silty shale and then into mudstone and finegrained sandstone (interpreted as distal-shelf turbidite deposits). These strata grade farther eastward into coarser-grained sandstone (interpreted as shallow-marine-shelf deposits that grade eastward into paralic to fluvial-deltaic deposits). The section is capped by red beds (interpreted as fluvial deposits and paleosols). The cross section (fig. 7) illustrates the overall coarsening-upward nature of the strata, with black mudstone at the base grading upward into red beds.

Harper (1999, table 7-1, figure 7-15) described and illustrated five facies (Facies I through V) of the Middle to Upper Devonian siliciclastic strata below the Kaskaskia I-Kaskaskia II unconformity in Pennsylvania and Ohio (fig. 8). Facies I consists of "dark-gray to black, somewhat calcareous, pyritic, sparsely fossiliferous shales" (Harper, 1999, table 7-1) that are interpreted as distal marine muds that accumulated under anoxic conditions (Ettensohn, 1985a). Facies I includes at least eight repetitive lithologic sequences, each represented 
by tongues of black shale that are intercalated with coarsergrained siliciclastic strata (figs. 8, 9). This facies is represented by the Middle Devonian Marcellus Shale in Pennsylvania and Ohio and the Lower Mississippian Sunbury Shale in Ohio. Facies II consists of sparsely fossiliferous "interbedded dark-gray shales and thin-bedded, light- to medium-gray siltstones" (Harper, 1999, table 7-1) that are interpreted as turbidite deposits that accumulated on a delta-fed submarine ramp (Lundegard and others, 1985). This facies is represented by the Brallier Formation. Facies III consists of "light- to dark-colored greenish, brownish, purplish, or reddish, highly fossiliferous shales, siltstones, and fine-grained sandstones" that are interpreted as "shallow marine open shelf" deposits (Harper, 1999, table 7-1). This facies is represented by the Upper Devonian Chadakoin Formation, Oswayo Formation, and Riceville Shale in western Pennsylvania (fig. 4). Facies IV consists of "interbedded silty, micaceous mudrocks and fineto coarse-grained, thin- to thick-bedded siltstones, sandstones, and conglomerates" as well as beds of limestone (Harper, 1999, table 7-1). This facies is interpreted as a mixture of fluvial-deltaic and linear shoreline deposits that are interspersed with open-marine carbonate deposits, which accumulated during episodes of eustatic sea-level rise. This facies is represented by the Elk, Bradford, and Venango Groups in Pennsylvania (equivalent to the Upper Devonian Sherr and Foreknobs Formations of the Greenland Gap Group in West Virginia and Maryland). Facies V consists of gray to red siliciclastic strata that are interpreted as "mixed continental, fluvial-deltaic, and marginal marine" deposits (Harper, 1999, table 7-1). This facies is represented by the Upper Devonian Catskill Formation in Pennsylvania (equivalent to the Hampshire Formation in West Virginia, Virginia, and Maryland).

In much of the basin, the Middle Devonian through Upper Devonian siliciclastic strata below the Kaskaskia IKaskaskia II unconformity are divided into a lower unit of siliciclastic strata (the Hamilton Group and equivalent strata), a middle unit of limestone (the Middle Devonian Tully Limestone) that is capped by a regional unconformity, and an upper unit of siliciclastic strata (the Middle to Upper Devonian Genesee Formation and Harrell Shale, and the Upper Devonian Sonyea Formation, West Falls Formation, Java Formation, Perrysburg Formation, and Ohio Shale). In some areas, the Tully Limestone is absent and only the regional unconformity separates the lower siliciclastic strata from the upper siliciclastic strata.

\section{Hamilton Group and Equivalent Strata}

The Hamilton Group includes the Marcellus Shale and Mahantango Formation in West Virginia and the Marcellus, Skaneateles, Ludlowville, and Moscow Shales in New York. The group term is not used in Ohio, Maryland, or Pennsylvania, although the Marcellus Shale is present in those States (fig. 4). The Marcellus Shale is best developed in central Pennsylvania, where it is up to $200 \mathrm{ft}$ thick (de Witt and others,
1993). To the south and west, the Marcellus Shale grades upward into silty shale of the Mahantango Formation, which in turn grades laterally into the Millboro Shale in Virginia (fig. 4). The Millboro Shale is about $1,500 \mathrm{ft}$ thick in western Virginia (Woodrow and others, 1988), where it includes all strata from the top of the Tioga Ash Bed to the base of the Brallier Formation (Hasson and Dennison, 1988). In Ohio, the Marcellus Shale is replaced by the Delaware Limestone to the west, and the Mahantango Formation is replaced by the Plum Brook Shale, Prout Limestone, and lower part of the Olentangy Shale (fig. 4). In central Pennsylvania and eastern New York, the Marcellus Shale and Mahantango Formation grade laterally into thin limestone and (or) fossiliferous sandstone and shale (Woodrow and others, 1988).

\section{Tully Limestone and the Acadian Unconformity}

The Hamilton Group and equivalent strata are overlain by the uppermost Middle Devonian Tully Limestone (figs. 7, 9), which is capped by the regional Acadian unconformity (Sloss, 1988; Swezey, 2002). The Tully Limestone extends from west-central New York to northern West Virginia. In general, the formation is a cobbly weathering, fossiliferous, silty limestone. The Tully Limestone is as much as $200 \mathrm{ft}$ thick in northcentral Pennsylvania (de Witt and others, 1993), but thins and is replaced by a zone of pyrite nodules and pyritized fossils in western New York (Woodrow and others, 1988; Sessa, 2003).

In eastern Kentucky and Ohio, the Tully Limestone is absent, but the major regional Acadian unconformity is present. In central Tennessee and south-central Kentucky around the edges of the Nashville dome (fig. 6), the unconformity cuts so deeply into the section that Upper Devonian strata overlie strata as old as Ordovician (de Witt and others, 1993; J.A. Drahovzal, written commun, as cited in Wickstrom, 1996). Baranoski and others (1996) and Nuttall (1996) describe a similar situation on the Cincinnati arch (fig. 6).

\section{Post-Acadian Unconformity Siliciclastic Strata}

The Devonian regional Acadian unconformity is overlain by several shale units of Devonian and Early Mississippian age (de Witt and others, 1993). These Upper Devonian shale units include the Renwick Shale Member and Geneseo Shale Member of the Genesee Formation, the Burket Member of the Harrell Shale, the Middlesex Shale Member of the Sonyea Formation, the Rhinestreet Shale Member of the West Falls Formation, the Pipe Creek Shale Member of the Java Formation, the Dunkirk Shale Member and Hume Shale Member of the Perrysburg Formation, and the Huron Member and Cleveland Member of the Ohio Shale (figs. 4, 7, 9). The black shale units are almost all regionally extensive and are interbedded with gray and greenish-gray siltstone and finegrained sandstone that contain relatively small amounts of organic matter (de Witt and others, 1993). Those shale units near the bottom and middle parts of the Devonian stratigraphic 
section (Marcellus Shale through Rhinestreet Shale Member of the West Falls Formation) are located mainly in the eastern part of the basin, and those shale units in the middle and upper parts of the section (Ohio Shale) are located mainly in the western part of the basin and, in part, overlie the Cincinnati arch (de Witt and others, 1993). The beds of gas-bearing Middle Devonian black shale grade upward and eastward into coarser-grained siliciclastic strata of the Brallier Formation. Partial equivalents of the Brallier Formation include the Scherr and Foreknobs Formations of the Greenland Gap Group in West Virginia and Maryland (fig. 4) and the Trimmers Rock, Lock Haven, and Catskill Formations in eastern Pennsylvania (Harper, 1999, figure 7-4).

\section{Upper Devonian Through Lower Mississippian Siliciclastic Strata Above the Kaskaskia I- Kaskaskia II Unconformity}

A regional unconformity is present within the uppermost Devonian strata, in most places beneath the Upper Devonian Berea Sandstone (fig. 4). This unconformity is overlain by Upper Devonian through Lower Mississippian siliciclastic strata (for example, the Sunbury Shale, the Rockwell Formation, Purslane Sandstone, and Burgoon Sandstone; see figures 3 and 4). In southwestern Virginia and adjacent West Virginia, these Upper Devonian through Lower Mississippian siliciclastic strata above the Kaskaskia I-Kaskaskia II Unconformity include the upper part of the Devonian-Mississippian Chattanooga Shale and the overlying Lower Mississippian Price Formation (fig. 10). In outcrops in this area, the Chattanooga Shale consists of the following three members: (1) a lower black shale member, (2) a middle gray siltstone member, and (3) the Big Stone Gap Member (black shale). The upper 131 $\mathrm{ft}$ of the Big Stone Gap Member consist of gray and grayishblack shale and are equivalent to the Lower Mississippian Sunbury Shale (Filer and others, 1996). In the subsurface, the Sunbury Shale is a 110-ft-thick unit of grayish-black to gray shale, which is overlain by the Price Formation (Filer and others, 1996).

\section{Devonian and Mississippian Shale Depositional Models}

Numerous interpretations of depositional environments have been applied to the Devonian and Mississippian strata in the Appalachian basin. Some models interpret the black shale as deposits of black mud that was rich in organic matter and that accumulated in the distal parts of the foreland basin, perhaps during periods of marine transgression (Ettensohn and Barron, 1981, 1982; Ettensohn, 1985a,b; Kepferle, 1993; Leone and Smith, 2011). Dennison (1985) proposed a model where Middle Devonian sea-level transgressions generally resulted in the deposition of limestone, and Late Devonian transgressions (after the deposition of the Tully Limestone) resulted in the deposition of black shale. He suggested that the following black shale units may have been deposited during periods of relative sea-level rise, as deltaic environments generally shifted eastward: (1) the Middle to Upper Devonian Geneseo Shale Member of the Genesee Formation, the Middle to Upper Devonian Harrell Shale, the Upper Devonian Rhinestreet Member of the West Falls Formation, and the Upper Devonian Pipe Creek Shale Member of the Java Formation; (2) the Famennian Dunkirk Shale Member of the Perrysburg Formation (Over, 2002); and (3) the unnamed lower black shale member and Big Stone Gap Member of the Upper Devonian to Lower Mississippian Chattanooga Shale (fig. 9).

Lundegard and others (1985) interpreted the Brallier Formation and overlying siliciclastic beds as having accumulated in the following five depositional environments: (1) delta front, (2) turbidite slope, (3) interlobe slope, (4) lobe margin, and (5) deep basin. Their paleocurrent map shows a consistent westward trend for the direction of transport of the Brallier sediments.

Boswell and Donaldson (1988) compared the sea-level curve of Johnson and others (1985) with the inferred positions of Late Devonian deltaic shorelines. They showed a correlation between sea level and late Late Devonian (Famennian) shoreline positions, but not between sea level and early Late Devonian (Frasnian) shoreline positions. From this comparison, they concluded that a global change in sea level, perhaps driven by glaciation in Gondwanaland, was an important factor for controlling Famennian sediment accumulation. During the Frasnian, however, the supply of sediments resulting from erosion during the Acadian orogeny may have overwhelmed the effects of glacially driven sea-level changes and could explain why there is no correlation between Frasnian shoreline positions and the Euramerican sea-level curve.

Many studies noted that Devonian and Mississippian black shale in the Appalachian basin displays an apparently cyclical nature. Ettensohn (1985a,b), for example, described five depositional cycles of finer-grained to coarser-grained rock within the Devonian siliciclastic strata. Each cycle is interpreted to have begun with a period of rapid subsidence in the basin, when black shale in the lower part of a cycle accumulated during a period of relative sea-level rise. This initial basin subsidence occurred in conjunction with (or was followed closely by) a period of tectonic uplift. According to this model, the coarser-grained clastic strata in the upper part of each cycle accumulated during a second period of subsidence, which followed the main tectonic event. Each of the following five black shale units described by Ettensohn (1985a,b) comprise the base of a cycle: (1) the Middle Devonian Marcellus Shale and the Mahantango Shale, (2) the Middle Devonian Geneseo Shale Member of the Genesee Formation and Burket Member of the Harrell Shale, (3) the Upper Devonian Middlesex Shale Member of the Sonyea Formation, (4) the Upper Devonian Rhinestreet Shale Member of the West Falls Formation, and (5) the Upper Devonian Dunkirk Shale Member of the Perrysburg Formation (fig. 4). Each of the black shale units 
and the immediately overlying beds of coarser-grained strata constitute one cycle.

Cyclical patterns were also noted by Kepferle (1993), Filer (1994), and Schieber (1998). For example, Kepferle (1993) cited evidence for four to eight transgressive and regressive events in the Appalachian basin during the Devonian and Mississippian. Filer (1994) proposed that there are seven or more basinwide third-order cycles of organic-matterrich black shale (including the Marcellus Shale and associated strata) intercalated generally with coarser-grained strata that contain much less organic material. Schieber (1998) recognized numerous extensive unconformities within the Upper Devonian to Lower Mississippian Chattanooga Shale in central Tennessee and adjacent Kentucky. He interpreted these unconformities as subtle sequence boundaries that reflect a temporary lowering of sea level, and he used these unconformities to divide the Chattanooga Shale into 14 regional sequences.

More recently, Filer (2002) described 11 cyclic lithologies in an interval of Upper Devonian strata from the upper part of the Rhinestreet Shale Member of the West Falls Formation to the Dunkirk Shale Member of the Perrysburg Formation in New York. These cycles were correlated through equivalent strata (parts of the Brallier Formation, Greenland Gap Group, Ohio Shale, and lower black shale member of the Chattanooga Shale) in a region that extends 435 miles (mi) or more along the length of the Appalachian Basin Petroleum Province from New York southwestward through Pennsylvania, Ohio, and West Virginia to eastern Kentucky and Tennessee and southwestern Virginia. In the western (distal) part of the basin, each of these cycles consists of dark, organicmatter-rich shale at the base that grades upward into lightercolored shale that contains less organic material. In the eastern (proximal) part of the basin, each of these cycles consists of relatively thin shale beds at the base that grade upward into relatively thick beds of siltstone and sandstone. In general, the cycles range from 2 to $3 \mathrm{ft}$ thick in the western part of the basin to as much as $230 \mathrm{ft}$ thick in the eastern part of the basin. Filer (2002) concluded that these basinwide high-frequency cycles were affected by glacially induced sea-level changes.

\section{Petroleum Geology}

Several estimates of undiscovered hydrocarbon resources of the Appalachian Basin Petroleum Province have been published. In 1995, for example, the USGS published assessments of the undiscovered hydrocarbon resources in Devonian shale in the Appalachian Basin Petroleum Province (Gautier and others, 1995). Briggs and Tatlock (1999) estimated the undiscovered recoverable natural gas resources in Pennsylvania. The 2002 USGS assessment (Milici and others, 2003) differs from these earlier assessments in that it was based on the concept of total petroleum systems, which considers source rocks, maturation, migration, reservoir rocks, and reservoir seals (Magoon and Dow, 1994).

\section{Assessment Model}

For assessment purposes, oil and gas reservoirs are commonly divided into the following two distinct types: conventional and continuous (unconventional). Conventional resources are characterized by discrete structural, stratigraphic, or combination traps in which water and oil and natural gas are separated into layers by their immiscibility and relative buoyancies. In contrast, continuous accumulations are accumulations of hydrocarbons (generally gas) that are not segregated into discrete fields with well-defined fluid contacts. Instead, continuous accumulations produce hydrocarbons, if only in small and potentially noneconomic amounts, wherever they are drilled. Such continuous reservoirs include coal (as coalbed methane), shale that is rich in organic material, and low-porosity (tight) sandstone (Schmoker, 1999, 2002). In the Appalachian Basin Petroleum Province, continuous accumulations commonly consist of multiple coal beds, sandstone beds, or shale beds that are amalgamated into larger stratigraphic units in which multiple zones may be drilled, perforated, and completed within a single well.

\section{Thermal Maturity Data}

For the 2002 USGS assessment of the Devonian ShaleMiddle and Upper Paleozoic TPS, thermal maturity data were obtained by vitrinite-reflectance (Milici and Swezey, 2006). These data were obtained from the following shale units in the lower part of the Devonian siliciclastic section: (1) the Marcellus Shale in the eastern part of the Appalachian Basin Petroleum Province, and (2) the slightly younger basal shale units to the west where the Marcellus Shale has pinched out. The vitrinite in samples of these shale units consisted of dispersed fragments of organic matter within a shale and siltstone matrix. Shale samples were collected under the direction of Robert T. Ryder (USGS) in cooperation with staff from the State geological surveys, and were analyzed by Humble Geochemical Services, Humble, Texas. The analyses of these data, as well as the vitrinite-reflectance isolines and the limits of oil generation and preservation in Devonian shale shown in figure 11, are taken from Weary and others $(2000,2001)$, Repetski and others $(2002,2005,2008)$, and John R. Repetski (USGS, oral commun., 2008). Vitrinite-reflectance data are expressed as percentages $\left(\% \mathrm{R}_{\mathrm{o}}\right)$ of light reflected back from a sample that is illuminated when compared with material that provides 100 percent reflectance (such as a mirror). In general, $0.6 \% \mathrm{R}_{\mathrm{o}}$ is regarded as the approximate lower limit of thermal maturity for oil generation, and $2.0 \% \mathrm{R}_{\mathrm{o}}$ is the approximate upper limit for oil preservation (Tissot and Welte, 1984; Taylor and others, 1998). Additional data on thermal maturity of Devonian shale may be found in East and others (2012).

During the 2002 USGS assessment, estimates of vitrinitereflectance values from Devonian dispersed vitrinite in Ohio, northwestern Pennsylvania, and New York may have been lower than the true vitrinite-reflection values because of a phenomenon described by Lo (1993) as "vitrinite reflectance 
suppression." Recent work by Rowan, Ryder, Repetski and others (2004); Rowan, Ryder, Swezey and others (2004); Rowan (2006); and Ruppert and others (2010) has determined that the vitrinite-reflectance values obtained from Pennsylvanian coal beds are, in general, equal to or greater than the values obtained from dispersed vitrinite in underlying Devonian shale, especially in the western part of the basin. Thermal or burial history models constructed along Appalachian Basin Petroleum Province cross section $E-E^{\prime}$ (fig. 12) of Ryder and others (2008) have determined that the $0.6-\% \mathrm{R}_{\mathrm{o}}$ isoline in Devonian shale may well lie 20 to 60 miles to the west of the line determined from dispersed vitrinite (Rowan, Ryder, Repetski and others, 2004; Rowan, Ryder, Swezey and others, 2004; Rowan, 2006; Ruppert and others, 2008). Indeed, vitrinite-reflection data obtained after the 2002 assessment, as well as older data corrected for vitrinite suppression (Repetski and others, 2008), have shown that the $0.6-\% \mathrm{R}_{\mathrm{o}}$ isoline could lie along the westernmost occurrence of the Devonian shale (fig. 13). Thus, much of the oil in the Devonian shale of central Ohio may have been generated in place, with little or no lateral migration from source rocks to the east.

Since the 2002 USGS assessment, basin modeling by Elisabeth L. Rowan (USGS, written commun., December 2004; Rowan, 2006) has indicated that the base of the Devonian shale entered the oil window during the Early Devonian at about 275 million years ago (Ma) in central Ohio and at about $340 \mathrm{Ma}$ (Early Pennsylvanian) in west-central West Virginia. Near the Ohio-West Virginia border, basal Devonian shale entered the oil window at about $330 \mathrm{Ma}$ (Middle Mississippian) and entered the gas window at about $230 \mathrm{Ma}$ (Middle Triassic).

\section{Petroleum System Data}

Petroleum system data for the Devonian Shale-Middle and Upper Paleozoic TPS include descriptions of petroleum source rocks, petroleum generation, petroleum migration, reservoir rocks, and reservoir seals (fig. 14). The petroleum source rocks are Middle and Upper Devonian and Lower Mississippian shale. The total organic carbon (TOC) content (in weight percent) of Devonian black shale of the Appalachian Basin Petroleum Province ranges widely from less than 1 percent to about 12 percent, but locally it can be as high as 27 percent (Zielinski and McIver, 1982). Hydrocarbon generation occurred from Early Devonian to Early Triassic, and hydrocarbon migration and accumulation occurred during hydrocarbon generation and shortly thereafter. The reservoirs range in age from Ordovician (strata in the Cumberland saddle region, which is located outside of the Appalachian Basin Petroleum Province in Kentucky and Tennessee; fig. 6) to Mississippian (strata in the Appalachian Plateau; fig. 6). Local seals include siltstone and shale throughout the section. Stratigraphic traps occur in sandstone and limestone throughout the section (de Witt and others, 1979). Some structural traps may have formed by extensional deformation during the late Precambrian and early Paleozoic formation of the Rome trough, but most structural traps formed by compression during the late Paleozoic Alleghanian orogeny, when the eastern part of the basin was folded and faulted.

The critical moment, which is considered to be the time when a large volume of the source rocks reaches thermal maturity and when large amounts of petroleum are generated and expelled from their source rocks, occurred during the Early Permian. During the critical moment, the source rocks and carrier beds were sufficiently fractured to facilitate migration and accumulation of liquid and gaseous hydrocarbons in porous reservoirs within available stratigraphic and structural traps. The residual hydrocarbons that remain within the source rocks after the critical moment constitute the continuous accumulations that are the subject of this paper.

In the Appalachian Basin Petroleum Province, methane and smaller amounts of other gases occur within Devonian shale in fractures of various sizes and (or) are adsorbed onto the surfaces of the large amounts of organic matter (de Witt and others, 1993). Charpentier and others (1993) classified these modes of occurrence as domains that contain macrofracture gas, microfracture gas, and sorbed gas. During production of these gases, the reservoir pressure is initially reduced as fractures are drained of formation waters, if present. Subsequently, as gas is produced from the fractures, additional gas is desorbed from the organic matter into microfractures and then into macrofractures on the way to the well bore. These processes are similar to the desorption and production of methane from coal beds (for a summary, see Markowski, 2001). Bustin and others (2006), however, demonstrated that the application of coalbed-methane-desorption techniques to most overmature gas shale units resulted in an overestimation of the adsorbed gas content and an underestimation of the free gas capacity of the shale. Instead, the use of production isotherms may result in a better estimation of the total reservoir capacity of gas in shale reservoirs.

\section{Devonian Gas Shale Assessment Units}

Most of the undiscovered petroleum resources in the Appalachian Basin Petroleum Province occur either within Devonian black shale as continuous autogenic (self-sourced) reservoirs (Milici, 1993) or within overlying and intertonguing Devonian siltstone and sandstone reservoirs (Schmoker, 1999, 2002). Of the 10 assessment units identified in the Devonian Shale-Middle and Upper Paleozoic TPS, 4 are conventional and 6 are continuous (table 1). This chapter focuses on the 4 continuous Devonian shale assessment units, which are named the Greater Big Sandy Assessment Unit (AU), the Northwestern Ohio Shale AU, the Devonian Siltstone and Shale AU, and the Marcellus Shale AU (fig. 15). The petroleum geology of these assessment units is summarized in Boswell (1996), Milici (1996a), and Milici and Swezey (2006). In addition, gas data were compiled from Roen and Kepferle (1993), Roen and Walker (1996), and the U.S. Department of Energy Eastern Gas Shales Project (U.S. Department of Energy, National Energy Technology Laboratory, 2007). 


\section{Greater Big Sandy Assessment Unit}

The Greater Big Sandy Assessment Unit (AU) is a Devonian shale interval in parts of eastern Kentucky and adjacent regions in Tennessee, Virginia, and West Virginia. This assessment unit is located east of the $0.6-\% \mathrm{R}_{\mathrm{o}}$ Devonian thermal maturity isoline, which is based on dispersed vitrinite (fig. 16). Thus defined, the Greater Big Sandy AU is stratigraphically gradational with the Devonian Siltstone and Shale AU to the east and with the Northwestern Ohio Shale AU to the west. Gas and natural gas liquids have been produced from this area at depths that range from about 1,700 to $5,595 \mathrm{ft}$ (Boswell, 1996).

The thickness of the assessment unit decreases from about 2,500 $\mathrm{ft}$ in the northeastern part of the area to about $100 \mathrm{ft}$ in the southwestern part (figs. 17, 18). The thickness of coarser-grained siliciclastic strata generally increases relative to the total thickness of black shale and is also concurrent with the overall increase in thickness of strata to the northeast. The depositional strike is generally north to south and follows the general thickness trends of the assessment unit (fig. 16).

Stratigraphy.-The Greater Big Sandy AU consists of several beds of black shale that are interbedded with beds of gray and greenish-gray shale, siltstone, and fine-grained sandstone. The assessment unit includes all of the strata from the base of the Devonian Rhinestreet Shale Member of the West Falls Formation (or the base of the Marcellus Shale, where present) to the top of the Mississippian Sunbury Shale (figs. 17, 18). The Marcellus Shale occurs beneath the Rhinestreet Shale Member in a small area in the northeastern part of the assessment unit (fig. 17). The major black shale units in the assessment unit include the Rhinestreet Shale Member of the West Falls Formation, the lower and upper parts of the Huron Member of the Ohio Shale, and the Cleveland Member of the Ohio Shale. In addition, the relatively thin Pipe Creek Shale Member of the Java Formation may be productive in places. In general, the upper part of the Huron Member of the Ohio Shale grades into gray or greenish-gray shale, siltstone, and fine-grained sandstone to the east across the assessment unit and, together with Cleveland Member of the Ohio Shale, pinches out to the northeast.

Structure.-The relation of the Greater Big Sandy AU to the regional geologic structure is shown in figure 20. In general, this assessment unit extends northeastward from the Pine Mountain block in Kentucky and Virginia to the western side of the Rome trough in Kentucky and southern West Virginia (Shumaker, 1980). In their study of play 8 (Western Rome Trough; fig. 19), Charpentier and others (1993) related the fracture porosity in the Big Sandy gas field and adjacent areas to late Paleozoic vertical movements of normal faults associated with the Rome trough. Shumaker (1980), however, proposed that a limited décollement in the Devonian black shale was responsible for the development of a "porous fracture facies" within these rocks. Indeed, Charpentier and others (1993) described a "blowout zone" that occurred in Devonian shale beneath the Pine Mountain block (play 10 in figs. 19, 20), where drilling intersected the subhorizontal décollement of the Pine Mountain thrust fault within Devonian shale (Young, 1957).

Where they are of limited extent, décollements apparently enhance fracture development within black shale. In contrast, where deformation is extreme in fractured shale, relatively small pockets of gas under high pressure may be released with explosive intensity (Young, 1957). Charpentier and others (1993) proposed a region (play 9, Tug Fork; fig. 19) that was intermediate between the areas of limited décollement and the relatively larger décollement in which increased fracture porosity in Devonian shale was caused by both vertical movement along the Rome trough border faults and deformation related to thrusting. Shumaker (1993) studied the MidwayExtra and Cottageville fields (fig. 21) in the northern part of the Greater Big Sandy AU in West Virginia and concluded that (1) the fracture porosity induced by a décollement in the black shale was enhanced near or above low-relief basement structures, and (2) this "fracture permeability formed during Alleghanian detached deformation when the lower Huron shale was overpressured" (Shumaker, 1993, p. K17-K18).

In addition to the work by Shumaker $(1980,1993)$, the relation between limited décollements and the generation of extensional and contractional fracture porosity in the Appalachian region was described in detail by Harris and Milici (1977), Milici (1980), Milici and Statler (1980), and Milici and Gathright (1983). These studies confirm the observation that organic-rich (and perhaps overpressured) strata such as coal or shale (Shumaker, 1980, 1993) serve to localize bedding décollements with an associated array of extensional fractures.

Petroleum source rocks.-The petroleum source rocks for the Greater Big Sandy AU are thought to be the Devonian shale. The mass of organic carbon per unit of area in the stratigraphic section generally exceeds 1.8 pounds per square inch $\left(\mathrm{lb} / \mathrm{in}^{2}\right)$ of surface area (Schmoker, 1993). For the Greater Big Sandy AU, Streib (1981) reported that the total organic carbon (TOC) content of 5 samples from the Cleveland Member of the Ohio Shale in the Greater Big Sandy Assessment Unit averaged 3.89 percent (table 3 ).

Thermal maturity.-Devonian shale in most of the Greater Big Sandy AU has dispersed vitrinite-reflectance values within the range of 0.6 to $1.0 \%$ R (fig. 16), which is within the thermal maturity window for oil generation (Repetski and others, 2008). In the eastern part of the assessment unit, however, vitrinite-reflectance values attain a maximum of about $1.5 \% \mathrm{R}_{\mathrm{o}}$ (fig. 16), which is within the thermal maturity window for gas generation (Repetski and others, 2008). The kerogen types in the Greater Big Sandy AU are expected to be mixed types I, II, and III (Maynard, 1981; Zielinski and McIver, 1982). The model-predicted vitrinite reflectance values (Rowan, Ryder, Repetski and others, 2004; Rowan, Ryder, Swezey and others, 2004; Rowan, 2006) indicate that the basal Devonian shale in the northern part of the assessment unit entered the oil window at approximately 330 to $325 \mathrm{Ma}$ (Mississippian) and entered the gas window 
at approximately $230 \mathrm{Ma}$ (Triassic). In comparison, the upper part of the Ohio Shale appears to have entered the oil window at approximately $260 \mathrm{Ma}$ (Permian).

Reservoir and production data.-In the Greater Big Sandy AU, gas has been produced from the Marcellus Shale, the Rhinestreet Shale Member of the West Falls Formation, the Huron and Cleveland Members of the Ohio Shale, and the Sunbury Shale (fig. 8). Reservoir depths range from approximately $1,700 \mathrm{ft}$ to nearly $6,000 \mathrm{ft}$ (Boswell, 1996). The reservoir is extremely underpressured and has very low permeability values of $<0.0001$ millidarcies (Kendrick, 2009; Wrightstone, 2009). Log-derived porosity values in the Big Sandy field range from 1.5 to 11 percent, with an average of 4.3 percent (Boswell, 1996). The better gas shale reservoirs within the AU are characterized by pervasive gas-filled micropores in laminated black shale, siltstone, and fine-grained sandstone that contain networks of natural fractures (Patchen and Hohn, 1993).

The database that accompanies Roen and Walker (1996) lists 61 named fields that lie within the boundaries of the Greater Big Sandy AU (fig. 21). Several of these fields are located near or on the boundaries of adjacent assessment units. Although these fields are administrative entities for State regulatory agencies, the fields are part of the continuous accumulation that constitutes the Greater Big Sandy AU. In these fields, the average completion thicknesses range generally from 189 to $980 \mathrm{ft}$, with the greatest average thickness completed from the Fourmile-Branchland field in West Virginia. Cumulative production data (as of September 30, 1996) are not available for all of the fields, but the available data indicate that at least 3.7 trillion cubic feet (TCF) of gas have been produced from named fields in the Greater Big Sandy AU, and about 2.5 TCF of gas have been produced from the Big Sandy gas field alone. Although much of the gas production from the Big Sandy field (and from many other fields) is commingled with production from other stratigraphic units, most of the gas is apparently produced from the Devonian shale.

Several published estimates of gas resources in the area of the Greater Big Sandy AU exist, although they did not use the same methodology that was used in the 2002 USGS assessment. For example, Kuuskraa and Wicks (1984) and Kuuskraa and others (1985) estimated the gas-in-place resources in the Cleveland and Huron Members of the Ohio Shale and the Rhinestreet Shale Member of the West Falls Formation (within the area of the Greater Big Sandy Assessment Unit) at about 60 TCF. Charpentier and others (1993), however, estimated the mean gas-in-place resources in the approximate area of the assessment unit at about 76 TCF (table 2, fig. 19). The difference between these two estimates may be the result of the relatively low values for the estimated gas-inplace resources that Kuuskraa and others (1985) assigned to the counties in the western part of the assessment unit (their Setting II) (fig. 22), which is the area associated with the Western Rome Trough (play 8 of Charpentier and others, 1993). In addition, the estimated gas-in-place resources that Kuuskraa and Wicks (1984) and Kuuskraa and others (1985) assigned to all stratigraphic intervals are more than double the estimated gas-in-place resources that they assigned to the target intervals in their Setting I (fig. 22).

In the database that accompanies Roen and Walker (1996), the original gas-in-place resources for the Big Sandy field were estimated at approximately $20 \mathrm{TCF}$. In this database, the original gas reserves for this field were estimated as 3.4 TCF, the gas produced was estimated as $2.5 \mathrm{TCF}$, and the remaining reserves were estimated as approximately $900 \mathrm{BCF}$. Using data from Roen and Walker (1996), the distribution (by thirds) of estimated ultimate recovery (EUR) values of gas per well calculated for shale gas wells in this assessment unit in eastern Kentucky is illustrated in figure 23. At the median, the early third of the wells attained an EUR of about 73 million cubic feet (MMCF), the middle third attained about 105 $\mathrm{MMCF}$, and the late third attained about $90 \mathrm{MMCF}$.

USGS assessment results.-For the 2002 assessment of undiscovered, technically recoverable petroleum resources of the Appalachian Basin Petroleum Province, the USGS estimated a range of $3,877.33$ to $9,562.42 \mathrm{BCF}$ of gas and 34.06 to 104.50 million barrels (MMB) of natural gas liquids in the Greater Big Sandy AU. The mean values for these estimates are 6,322.67 $\mathrm{BCF}$ of gas and 63.23 MMB of natural gas liquids in the Greater Big Sandy AU (Milici and others, 2003).

\section{Northwestern Ohio Shale Assessment Unit}

The Northwestern Ohio Shale Assessment Unit (AU) is a Devonian shale interval that occupies an area in eastern Kentucky, east-central Ohio, western Pennsylvania, and western New York (figs. 12, 15). This assessment unit is located to the west of the $0.6-\% \mathrm{R}_{\mathrm{o}}$ Devonian thermal maturity isoline (based on dispersed vitrinite). The Northwestern Ohio Shale AU is stratigraphically gradational with the Greater Big Sandy AU to the southeast and with the Devonian Siltstone and Shale AU to the northeast (fig. 15).

The thickness of Devonian strata in the assessment unit ranges from about $25 \mathrm{ft}$ in southern Kentucky and adjacent Tennessee to about $4,000 \mathrm{ft}$ in the northern panhandle of West Virginia (fig. 5). The thickest accumulation of black shale, however, extends northward from easternmost Kentucky through Ohio (fig. 15), where the net thickness of black shale ranges generally from 200 to $400 \mathrm{ft}$. In general, the Northwestern Ohio Shale AU (fig. 15) contains much of the thicker accumulations of black shale in the Devonian strata.

Stratigraphy.-The Northwestern Ohio Shale AU includes all of the shale strata from the base of the Rhinestreet Shale Member of the West Falls Formation to the top of the Sunbury Shale (figs. 24, 25, 26). The major black shale units in the assessment unit are the Rhinestreet Shale Member of the West Falls Formation and the Huron Member of the Ohio Shale. The Pipe Creek Shale Member of the Java Formation, the Cleveland Member of the Ohio Shale, and the Sunbury Shale are relatively thin, but may produce gas in places. Beds of black shale in the upper part of the Huron Member and the 
Cleveland Member of the Ohio Shale grade eastward across the assessment unit area into gray and greenish-gray shale, siltstone, and fine-grained sandstone of the Chagrin Shale (figs. 25, 26).

Structure.-The relation of producing areas in the Northwestern Ohio Shale AU to geologic structure is shown in figure 27. Although the assessment unit was assessed as a continuous accumulation, the commercial production of hydrocarbons depends largely on the local development of fracturegenerated porosity and permeability within the shale. In some places within the assessment unit, gas is produced with oil, but in other places natural gas is the only hydrocarbon produced. In yet other places (such as the Cumberland saddle region of south-central Kentucky and adjacent Tennessee, along the Cambridge structural discontinuity in central Ohio, and in northwestern Pennsylvania), gas is produced together with oil. The chief gas-producing areas in the Northwestern Ohio Shale AU are (1) adjacent to the Greater Big Sandy AU in eastern Kentucky, (2) along the northwestern edge of the Rome trough in southern Ohio, (3) along the Waverly arch in Ohio, and (4) the Lake Shore fields along the southern shore of Lake Erie in northern Ohio, Pennsylvania, and western New York (fig. 27). Gas production along the western margin of the Rome trough in southeastern Ohio may have been enhanced by fracture porosity related to late-stage movement along the western boundary fault (Charpentier and others, 1993).

When compared with the other Devonian shale assessment units, a structural interpretation of the Northwestern Ohio Shale AU is relatively simple. Glacial loading and rebound that were caused by the incursion and melting of continental ice sheets during the Pleistocene appear to have enhanced fracture porosity and permeability in the northwestern and northern parts of the assessment unit, especially in the Lake Shore fields (fig. 27) where fractures extend to depths of 1,000 to $1,500 \mathrm{ft}$ (Charpentier and others, 1993). To the east, in the panhandle of northwestern Pennsylvania and in western New York, beds of relatively brittle siltstone are intercalated with beds of Devonian black shale and are broken by an extensive network of fractures that also appears to have formed in response to several episodes of glacial loading and crustal rebound. The combination of natural fractures and thin, broken beds of siltstone interbedded with the thick beds of black shale has enhanced gas production from Devonian shale in this area (Charpentier and others, 1993).

East of the Cambridge structural discontinuity, a relatively large area in eastern Ohio, western Pennsylvania, and northern West Virginia is underlain by evaporite beds in the Silurian Salina Group. The evaporite beds contain a widespread subhorizontal bedding-parallel fault that exhibits only a relatively small amount of displacement (Frey, 1973). In the region to the east of the Northwestern Ohio Shale AU, this fault is a décollement that has had sufficient movement on it to generate numerous blind splay thrust faults and a series of relatively low relief, subparallel, superficial anticlines within hanging-wall strata. The folding is a reflection of the amount of shortening that has taken place in the strata overlying the décollement in the Salina Group (fig. 27). This décollement has been recognized as far west as the Bass Islands trend (fig. 27) in southwestern New York (Beinkafner, 1983; Patenaude and others, 1986; Van Tyne, 1996). Nevertheless, an extension of the décollement within evaporite beds in the Salina Group westward into Ohio to the vicinity of the Cambridge structural discontinuity is speculative. Fractures in Devonian strata that are related to movement along the Salina décollement may be present along the northeastern margin of the Northwestern Ohio Shale AU, generally from southeastern Ohio, through the panhandle of West Virginia, to the Bass Islands trend (fig. 27) in southwestern New York (Charpentier and others, 1993; Shumaker, 1996, fig. 6).

Petroleum source rocks.-The petroleum source rocks for the Northwestern Ohio Shale AU are thought to be the Devonian shale. The greatest thickness of Devonian black shale extends from the Greater Big Sandy AU in eastern Kentucky northward into eastern Ohio, where the cumulative thickness of potential source rocks locally exceeds $400 \mathrm{ft}$ (fig. 15; de Witt and others, 1993, fig. 2). Kerogen types in this area are generally derived from marine biota, especially algae (Tasmanites), and are commonly type I and II kerogens, which are prone to generate oil as well as natural gas (Maynard, 1981; Zielinski and McIver, 1982). Although vitrinite-reflectance data from dispersed organic matter in the Devonian shale indicate that this area is thermally immature to marginally mature with respect to oil generation (figs. 11, 13), oil is found in wells scattered throughout much of the assessment unit (figs. 27, 28). Streib (1981) reported that the total organic carbon (TOC) content of 6 samples from the Cleveland Member of the Ohio Shale averaged about 7.46 percent in Gallia County, Ohio (table 3).

Thermal maturity.-Devonian shale in most of the Northwestern Ohio Shale AU has dispersed vitrinite values within the range of 0.6 to $0.79 \% \mathrm{R}_{\mathrm{o}}$ (figs. 12,13), which is within the thermal maturity window for oil generation (Repetski and others, 2008). On the basis of the burial history curve for the Amerada No. 1 Ullman well in Noble County, Ohio (figs. 24, 29), the lower part of the Devonian shale in the eastern part of the Northwestern Ohio Shale AU appears to have entered the oil window sometime during the Middle Triassic (Ryder and others, 1998), but subsequent work on the Ullman well indicates that basal Devonian shale in southeastern Ohio entered the oil window during the Mississippian and entered the gas window during the latest Permian or earliest Triassic (Rowan, Ryder, Repetski, and others, 2004; Rowan, Ryder, Swezey and others, 2004; Rowan, 2006). In this area, the top of the Devonian shale entered the oil window during the latest Permian or earliest Triassic, but remained immature with regard to thermal generation of natural gas. The western part of the Northwestern Ohio Shale AU in Ohio may be generally immature with respect to the generation of hydrocarbons (Repetski and others, 2008).

Reservoir and production data.-In the Northwestern Ohio Shale AU, the stratigraphic names and reservoir data vary from State to State. In much of Ohio, the Devonian shale 
source rocks and reservoirs consist predominantly of the Huron and Cleveland Members of the Ohio Shale (figs. 25, 26). In western New York, the producing units are the Dunkirk Shale Member of the Perrysburg Formation, the Rhinestreet Member of the West Falls Formation, and the Marcellus Shale (fig. 9). The available gas field data (fig. 29) show that the average thickness completed (by field) ranges up to $352 \mathrm{ft}$ in northeastern Kentucky (Naples field), up to $600 \mathrm{ft}$ in eastern Ohio (Brookville field), and up to $378 \mathrm{ft}$ in western West Virginia (Apple Grove field). The depths to the producing reservoirs range generally from about $365 \mathrm{ft}$ in north-central Ohio (Lewin and Associates, 1983) to 2,300 ft in southern Ohio and to $4,000 \mathrm{ft}$ or more in western West Virginia and adjacent Kentucky. The average log-derived porosity values range from about 3 to 14 percent in the Newton field in central Ohio, and up to 16 percent in the Darlington field in western Pennsylvania (Roen and Walker, 1996). Maximum porosity values of 8 and 9 percent have been reported for other fields (Boswell, 1996). Lewin and Associates (1983) used nominal values of 1 percent for shale matrix porosity and $5 \times 10^{-6}$ millidarcies for shale matrix permeability. Soeder and others (1986) observed that shale samples from wells in the lower part of the Huron Member of the Ohio Shale in southeastern Ohio and northwestern West Virginia contain liquid petroleum in their pores. As a result, the ratio of matrix permeability to gas is very low (in the range of tens of nanodarcies), and gas-filled porosity is generally less than 0.1 percent (Soeder and others, 1986).

The database that accompanies Roen and Walker (1996) lists 49 named gas fields within the boundaries of the Northwestern Ohio Shale AU (fig. 28). Although these fields are administrative entities for State regulatory agencies, the fields are part of the continuous accumulation that constitutes the Northwestern Ohio Shale AU. Cumulative production data are generally not available from these fields, and much of the gas production from the Northwestern Ohio Shale AU is commingled with production from other stratigraphic units.

Several published estimates of gas resources in the area of the Northwestern Ohio Shale Assessment Unit exist, although they did not use the same methodology that was used in the 2002 USGS assessment. For example, Lewin and Associates (1983), Kuuskraa and Wicks (1984), and Kuuskraa and others (1985) portioned areas of Ohio, West Virginia, and Kentucky into different geological settings (fig. 30), and they estimated the gas-in-place resources in the Ohio Shale and the Rhinestreet Shale Member of the West Falls Formation (within the area of the Northwestern Ohio Shale Assessment Unit) to be about 112 TCF. Charpentier and others (1993), however, estimated the mean gas-in-place resources in the approximate area of the assessment unit to be about 245 TCF (table 2, fig. 19).

Using data from Roen and Walker (1996), the distribution (by thirds) of estimated ultimate recovery (EUR) values of gas per well calculated for shale gas wells in the Northwestern Ohio Shale AU is shown in figure 31. At the median, the early third of the wells attained an EUR of about $37 \mathrm{MMCF}$, the middle third attained about $48 \mathrm{MMCF}$, and the late third attained about $40 \mathrm{MMCF}$.

USGS assessment results.-For the 2002 assessment of undiscovered, technically recoverable petroleum resources of the Appalachian Basin Petroleum Province, the USGS estimated a range from $1,453.59$ to $4,338.99 \mathrm{BCF}$ of gas and from 25.95 to 93.32 million barrels (MMB) of natural gas liquids in the Northwestern Ohio Shale AU. The mean values for these estimates are 2,654.07 BCF of gas and 53.08 MMB of natural gas liquids in the Northwestern Ohio Shale AU (Milici and others, 2003).

\section{Devonian Siltstone and Shale Assessment Unit}

The Devonian Siltstone and Shale Assessment Unit (AU) extends across the Appalachian Basin Petroleum Province from western New York through western Pennsylvania and central West Virginia into southwestern Virginia (figs. 15, 32). This assessment unit follows the depositional strike throughout much of the basin, except at its northern end in New York. The western boundary of the assessment unit lies along the $0.6-\% \mathrm{R}_{\mathrm{o}}$ Devonian thermal isoline in New York, Pennsylvania, and Ohio (fig. 12, 15). To the south in West Virginia and Virginia, the western boundary of the assessment unit lies along the eastern margin of the Greater Big Sandy AU. This assessment unit is generally coincident with much of the area occupied by play Dbg (Upper Devonian fractured black and gray shales and siltstones) of Milici (1996a), and the geology of the region is described in more detail there. The Devonian Siltstone and Shale AU is geographically intermediate between shale of the Greater Big Sandy AU and the Northwestern Ohio Shale AU on the west and coarser-grained strata of the Catskill Sandstones and Siltstones AU on the east (Filer, 1985; Boswell, Heim, and others, 1996a; Boswell, Thomas, and others, 1996b; Donaldson and others, 1996). The Devonian Siltstone and Shale AU includes the "emerging area" of Patchen and Hohn (1993) in northwestern West Virginia.

The overall thickness of the Devonian section in the area of the assessment unit ranges from $1,000 \mathrm{ft}$ or less in western New York to $6,000 \mathrm{ft}$ in central Pennsylvania. The thickness of the Devonian strata in the assessment unit thin farther to the south to less than 1,000 ft in southwestern Virginia (fig. 32). The net thickness of the black shale in the assessment unit ranges from less than $100 \mathrm{ft}$ in West Virginia to a little more than $500 \mathrm{ft}$ in southwestern New York and adjacent Pennsylvania (fig. 16).

Stratigraphy.-The Devonian Siltstone and Shale AU generally lies between the eastern limit of the upper black shale tongue of the Huron Member of the Ohio Shale and the eastern limit of the Rhinestreet Shale Member of the West Falls Formation (fig. 4). The Devonian Siltstone and Shale AU consists of dark-gray to black shale that is interbedded with gray and greenish-gray shale and siltstone (de Witt and others, 1993). The assessment unit includes all of the strata from the 
base of the Hamilton Group (Marcellus Shale) to the top of the Sunbury Shale. The major black shale units in the assessment unit are the Marcellus Shale at the base, the Pipe Creek Shale Member of the Java Formation, the lower part of the Huron Member of the Ohio Shale, and the Dunkirk Shale Member of the Perrysburg Formation (figs. 4, 25, 26).

Structure.-The relation of producing areas in the Devonian Siltstone and Shale AU to geologic structure is shown in figure 33. Much of the assessment unit is deformed to some extent by a limited décollement in Devonian shale in the area south of the Rome trough in southern West Virginia and southwestern Virginia. North of the trough, in northwestern Pennsylvania, a limited décollement within evaporite beds of the Silurian Salina Group has resulted in shortening and folding of the hanging wall into a series of relatively low amplitude folds (fig. 27). The coincidence of a subhorizontal décollement within the black shale, the fractured superficial anticlines that were formed by splay faults from the décollement in the underlying Silurian evaporite beds (Filer, 1985; Sweeney, 1986), and perhaps any late-stage movement on steeply dipping faults associated with the Rome trough (Caramanica, 1988) appear to have increased the fracture porosity within the assessment unit, especially where siltstone and fine-grained sandstone are intercalated with black shale. In the "emerging area" of Patchen and Hohn (1993) in northwestern West Virginia, the two main plays are the Huron Member of the Ohio Shale and the Rhinestreet Shale Member of the West Falls Formation. The fracture porosity within these shale units appears to be related to folds that were formed by a limited décollement in the underlying Silurian evaporite beds (Shumaker, 1993).

Petroleum source rocks.-The petroleum source rocks for the Devonian Siltstone and Shale AU are thought to be the Devonian shale. Except in southwestern New York and western Pennsylvania, the Devonian Siltstone and Shale AU lies along the eastern margin of thick shale, where the net thickness of black shale ranges from about $100 \mathrm{ft}$ to as much as $250 \mathrm{ft}$. In northern Pennsylvania, however, the net thickness of black shale is $500 \mathrm{ft}$ or more (fig. 15). Because the assessment unit is located in the center of the basin and presumably was close to the source of terrigenous clastic sediments, the Devonian Siltstone and Shale AU should contain greater proportions of type III kerogen than the assessment units to the west (Maynard, 1981; Zielinski and McIver, 1982). The geochemical characteristics of samples from the Devonian Siltstone and Shale AU are listed in table 3 (Streib, 1981). Streib (1981) reported that the total organic carbon (TOC) content of one sample from the Marcellus Shale in a well in Wetzel County, West Virginia, was 6.19 percent (table 3).

Thermal maturity.- On the basis of dispersed vitrinitereflectance data, the Devonian shale in the Devonian Siltstone and Shale AU is located to the east of the $0.6-\% R_{0}$ thermal isoline (fig. 11). The assessment unit, therefore, is thermally mature with respect to the generation of hydrocarbons. To the east, the assessment unit reaches the $2.0-\% \mathrm{R}_{\mathrm{o}}$ isoline (the eastern limit of oil preservation) in western Pennsylvania and the $4.0-\% \mathrm{R}_{\mathrm{o}}$ isoline in southern West Virginia (figs. 11, 12). Oil is commonly produced with gas in much of the assessment unit area because of the increased fracture porosity in the interbedded siltstones of the Devonian Siltstone and Shale AU (fig. 32). Where thermal maturity is the greatest in central Pennsylvania and in the southern part of the assessment unit, however, gas is the primarily produced hydrocarbon.

Model-predicted vitrinite-reflection values from three wells in the Devonian Siltstone and Shale AU in western West Virginia indicate that the base of the Devonian shale entered the oil window during the Pennsylvanian and entered the gas window during the Permian (Rowan, Ryder, Repetski, and others, 2004; Rowan, Ryder, Swezey, and others, 2004; Rowan, 2006). Calculated vitrinite-reflectance values for these wells (the No. 1 Gainer-Lee, the No. 1 McCoy, and the No. 1 Deem wells) are based on vitrinite-reflectance values from Pennsylvanian coal beds and are significantly greater than the values determined from dispersed vitrinite in the basal Devonian shale (fig. 12). For example, the calculated vitrinite-reflectance value for the No. 1 Gainer-Lee well is $2.17 \% \mathrm{R}_{0}$, which is significantly greater than the $1.5-\% \mathrm{R}_{\mathrm{o}}$ value to the east that was determined from vitrinite dispersed in the shale.

Reservoir and production data.-In the Devonian Siltstone and Shale AU, the principal gas-producing units are the Rhinestreet Shale Member of the West Falls Formation, the lower part of the Huron Member of the Ohio Shale, and (to a lesser extent) the Marcellus Shale (figs. 25, 26). Completion intervals range generally from 10 to nearly $1,600 \mathrm{ft}$, final open flow rates range from 30 to 1,500 thousand cubic feet (MCF) per day, and initial reservoir pressures range from 125 to 2,529 $\mathrm{lb} / \mathrm{in}^{2}$. Although the data are limited, log-derived porosity values are as high as 8 percent (see database that accompanies Roen and Walker, 1996). Drilling depths range from several hundred feet or more in New York to about 5,000 ft in West Virginia.

The database that accompanies Roen and Walker (1996) lists 68 named gas fields within the boundaries of the Devonian Siltstone and Shale AU (fig. 34). Of the few fields for which data are available, the average thickness completed was greatest at 1,590 ft in the Blue Creek field in Kanawha County, West Virginia (fig. 34). Although oil and gas exploration has occurred over much of the assessment unit (fig. 32), exploration has been concentrated in west-central West Virginia, which is the "emerging area" of Patchen and Hohn (1993). Patchen and Hohn (1993, p. L26) concluded "...that the overall emerging area of Devonian shale oil and gas production has been overpromoted and will prove to be non-commercial to many operators and investors." Subsequently, Douglas Patchen (West Virginia Geological and Economic Survey, written commun., 2005) indicated that production from wells drilled more recently has improved since their 1993 publication. In addition, production from many of the newer shale-gas wells is commingled with production from Devonian sandstone reservoirs. 
Several published estimates of gas resources in the area of the Devonian Siltstone and Shale AU exist, although they did not use the same methodology that was used in the 2002 USGS assessment. For example, Tetra Tech, Inc. (1981) estimated 482 TCF (black shale thickness determined from log data) to 790 TCF (black shale thickness determined from sample data) of gas-in-place resources in the approximate area of the assessment unit in Pennsylvania, with relatively favorable areas for shale gas occurring in the Rhinestreet Shale Member of the West Falls Formation and the Dunkirk Shale Member of the Perrysburg Formation in northeastern Pennsylvania and in the Marcellus Shale in west-central Pennsylvania (fig. 35). Lewin and Associates (1983) estimated that the Devonian shale in the approximate area of the assessment unit in Ohio contained 3.5 TCF (figure 35), and Kuuskraa and Wicks (1984) estimated that the Devonian shale in the approximate area of the assessment unit in West Virginia contained 53.4 TCF (figure 35). Charpentier and others (1993) estimated the mean gas-in-place resources in the approximate area of the assessment unit to be about 228 TCF (fig. 19, table 2).

Using data from Roen and Walker (1996), the distribution (by thirds) of estimated ultimate recovery (EUR) values of gas per well calculated for shale gas wells in this assessment unit is shown in figure 36. At the median, the early third of the wells attained an EUR of about $55 \mathrm{MMCF}$, the middle third attained about $33 \mathrm{MMCF}$, and the late third attained about 30 MMCF.

USGS assessment results.-For the 2002 assessment of undiscovered, technically recoverable petroleum resources of the Appalachian Basin Petroleum Province, the USGS estimated a range from 829.34 to $1,925.18 \mathrm{BCF}$ of gas and from 4.50 to $23.14 \mathrm{MMB}$ of natural gas liquids in the Devonian Siltstone and Shale AU. The mean values for these estimates are 1,293.61 BCF of gas and 31.05 MMB of natural gas liquids in the Devonian Siltstone and Shale AU (Milici and others, 2003).

\section{Marcellus Shale Assessment Unit}

The Marcellus Shale Assessment Unit (AU) extends southward from central Pennsylvania, southwestern New York, and eastern Ohio through West Virginia to southwestern Virginia. This assessment unit lies generally to the east of the Devonian Siltstone and Shale AU, where the thickness of Marcellus Shale is greater than $50 \mathrm{ft}$ (fig. 37).

Stratigraphy.-The Marcellus Shale AU includes the Hamilton Group (Marcellus Shale and Mahantango Formation) in much of the Appalachian basin and the Millboro Shale in Virginia (fig. 4). Although the Hamilton Group and the Millboro Shale may attain thicknesses of 1,000 ft and 1,500 ft, respectively, the net thickness of the black shale within these units ranges generally from less than $50 \mathrm{ft}$ in Ohio and the western parts of New York, Pennsylvania, and northern West Virginia to about $200 \mathrm{ft}$ in northeastern Pennsylvania (de Witt and others, 1993).
Structure.-The Marcellus Shale AU is underlain by a regional décollement in evaporite beds of the Silurian Salina Group (fig. 3) in the Appalachian Plateau region of Pennsylvania, northern West Virginia, and eastern Ohio (Frey, 1973). In this region, the Marcellus Shale is folded into numerous rootless folds, and interstratal slip during folding may have increased the fracture porosity within the shale.

Petroleum source rocks.-The petroleum source rocks for the Marcellus Shale AU are thought to be the Devonian shale. The total organic carbon (TOC) contents of samples from the Marcellus Shale (table 4) show that the organic richness of the Marcellus Shale decreases generally from New York southward to West Virginia (Weary and others, 2000, 2001; Repetski and others, 2002, 2005). These variations appear to reflect the overall paleogeography, with the higher TOC content in the more distal parts (New York) and the lower TOC content in the more proximal parts (West Virginia) of the siliciclastic depositional system. The TOC data presented in table 4 include samples of the Marcellus Shale that were collected from wells distributed across several of the assessment units. In general, the higher TOC values for the Marcellus Shale in New York occur in the Northwestern Ohio Shale AU and in counties that lie along the border of the Northwestern Ohio Shale AU and Devonian Siltstone and Shale AU (table 4). In New York, the TOC content of 19 samples of the Marcellus Shale averaged 4.3 percent (table 4), but only 8 of these 19 samples were collected within the area of the USGS Marcellus Shale Assessment Unit. In Pennsylvania, however, the TOC content of 36 samples averaged 3.61 percent (table 4), but only 23 of these 36 samples were collected from within the area of the USGS Marcellus Shale Assessment Unit. In West Virginia, the TOC content of 22 samples of the Marcellus Shale averaged 1.40 percent (table 4), but only 13 of these 22 samples were collected within the area of the USGS Marcellus Shale Assessment Unit.

Thermal maturity.-Devonian shale in much of the Marcellus Shale AU has dispersed vitrinite values of 1.5 to 3.0 $\% \mathrm{R}_{\mathrm{o}}$ (figs. 11, 12), which is within thermal maturity windows for gas generation (Repetski and others, 2008). In the Amerada No. 1 Ullman well, the maximum depth of burial of the Marcellus Shale ranges from about 7,000 to $10,000 \mathrm{ft}$ (fig. 29). Because of its more eastward location and greater depth of burial, the Marcellus Shale probably attained thermal maturity earlier during the Paleozoic than did stratigraphically higher Devonian shale to the west.

Reservoir and production data.-The database that accompanies Roen and Walker (1996) lists only one field (Genegants field in New York) in the Marcellus Shale AU (fig. 34). Wells in this field have been drilled to 2,000 ft or more and may bottom in Lower Devonian limestone.

Several published estimates of gas resources in the area of the Marcellus Shale AU exist although they did not use the same methodology that was used in the 2002 USGS assessment. For example, Kuuskraa and Wicks (1984) estimated the gas-in-place resources in the Marcellus Shale in eastern West Virginia to be about $101 \mathrm{TCF}$. In comparison, Charpentier and 
others (1993) estimated the mean gas-in-place resources in the Marcellus Shale in northern West Virginia, central Pennsylvania, and southwestern New York (in an area that is larger than the Marcellus Shale AU described in this publication) to be about 295 TCF (table 2). At a 10 percent recovery factor, these estimates would yield almost $30 \mathrm{TCF}$ of gas.

USGS assessment results.-For the 2002 assessment of undiscovered, technically recoverable petroleum resources of the Appalachian Basin Petroleum Province, the USGS estimated a range from 821.83 to $3,667.59 \mathrm{BCF}$ of gas and from 4.50 to $23.14 \mathrm{MMB}$ of natural gas liquids in the Marcellus Shale AU. The mean values for these estimates are 1,925.18 $\mathrm{BCF}$ of gas 11.55 MMB of natural gas liquids in the Marcellus Shale AU (Milici and others, 2003). USGS oil and gas assessments of the Appalachian Basin Petroleum Province are based largely on previous well performance within the assessment units. At the time of the 2002 assessment, very little drilling had occurred within the Marcellus Shale AU. Accordingly, the Greater Big Sandy AU was used as a partial analog for assessing the Marcellus Shale AU.

The area of the Marcellus Shale AU, as it was assessed by the USGS in the 2002, does not encompass the entire extent of the Marcellus Shale geologic unit. Some of the mapped extent of the Marcellus Shale extends to the east of the Marcellus Shale AU and into the Devonian Siltstone and Shale AU. A vitrinite reflectance value of $2 \% \mathrm{R}$ is taken as the boundary between the two assessment units. Although large amounts of gas are produced from Devonian shale to the west of the $2-\% R_{0}$ isoline, the thickness of the Marcellus Shale is less than $50 \mathrm{ft}$ to the west of this isoline in western New York, western Pennsylvania, western West Virginia, and eastern Ohio. Residual oil in this area of lower thermal maturity may clog porosity and interfere with gas production. Accordingly, the most productive area ("sweet spot") for the Marcellus Shale is thought to extend from south-central New York to southwesternmost Pennsylvania and then into adjacent West Virginia (fig. 37). In 2002, the USGS estimated that technically recoverable undiscovered gas resources in the Marcellus Shale AU ranged from a minimum of $0.83 \mathrm{TCF}$ to a maximum of 3.67 TCF (Milici and others, 2003). In 2008, Engelder (in Kane, 2008) estimated that the Marcellus Shale contained 1,307 TCF of gas. Engelder's study encompassed a larger area than the Marcellus Shale AU described in this publication and Engelder's estimates were based largely on estimated gas-inplace resources that he calculated for that area. Engelder and Lash (2008) estimated that the Marcellus Shale might contain more than 500 TCF of gas-in-place resources, of which about 10 percent (50 TCF) might be recoverable. More recently, Engelder (2009) estimated that, after a 50-year decline, the estimated ultimate recovery (EUR) values from the Marcellus Shale would range from about 221 TCF (a 90 percent chance of at least this amount) to $867 \mathrm{TCF}$ (a 10 percent chance of at least this amount), with a 50 percent probability that the Marcellus Shale would ultimately yield 489 TCF. In 2011, the USGS published a revised study of the Marcellus Shale (Coleman and others, 2011) that estimated that technically recoverable undiscovered gas resources in the Marcellus Shale ranged from 43 to $144 \mathrm{TCF}$. This revised USGS estimate, however, considered an area that is much larger than the Marcellus Shale AU of the 2002 USGS assessment.

\section{Summary}

In 2002, the U.S. Geological Survey (USGS) conducted an assessment of the technically recoverable undiscovered oil and gas resources of the Appalachian Basin Petroleum Province in the eastern United States. This assessment identified six total petroleum systems, one of which is the Devonian Shale-Middle and Upper Paleozoic Total Petroleum System (TPS). The oil and gas of this TPS are derived from Devonian shale, and the reservoir intervals encompass a variety of middle and upper Paleozoic strata. This TPS is divided into 10 assessment units (reservoir intervals), including the following four Devonian shale-gas assessment units: (1) the Greater Big Sandy AU, which is located primarily in eastern Kentucky; (2) the Northwestern Ohio Shale AU, which is located in eastern Kentucky, east-central Ohio, western Pennsylvania, and western New York; (3) the Devonian Siltstone and Shale AU, which extends across western New York through western Pennsylvania and central West Virginia into southwestern Virginia; and (4) the Marcellus Shale AU, which extends southward from central Pennsylvania, southwestern New York, and eastern Ohio through West Virginia to southwestern Virginia. These four AUs are composed of Devonian shale, siltstone, and fine-grained sandstone. They are considered to be continuous (unconventional) assessment units in which the shale is both the petroleum source rock and the reservoir interval. In the 2002 USGS assessment, the Greater Big Sandy AU was estimated to contain 3,877.33 to 9,562.42 billion cubic feet (BCF) of gas and 34.06 to 104.50 million barrels (MMB) of natural gas liquids. The Northwest Oil Shale AU was estimated to contain $1,453.59$ to $4,338.99 \mathrm{BCF}$ of gas and 25.95 to $93.32 \mathrm{MMB}$ of natural gas liquids. The Devonian Siltstone and Shale AU was estimated to contain 829.34 to $1,894.48$ $\mathrm{BCF}$ of gas and 17.35 to $50.08 \mathrm{MMB}$ of natural gas liquids. The Marcellus Shale AU was estimated to contain 821.83 to $3,667.59 \mathrm{BCF}$ of gas and 4.50 to $23.14 \mathrm{MMB}$ of natural gas liquids.

\section{Acknowledgments}

The writers thank Robert T. Ryder and Peter D. Warwick for their reviews, which substantially improved the quality of the manuscript. They are also indebted to the members of the USGS Appalachian Basin Petroleum Province Assessment Team (Robert T. Ryder, Ronald R. Charpentier, Troy A. Cook, Robert A. Crovelli, Timothy R. Klett, Richard M. Pollastro, and Christopher J. Schenk) for their part in conducting the 2002 Appalachian Basin Petroleum Province Assessment. 


\section{References Cited}

Baranoski, M.T., Riley, R.A., and Wolfe, M.E., 1996, Play COk; Cambrian-Ordovician Knox Group unconformity play, in Roen, J.B., and Walker, B.J., eds., The atlas of major Appalachian gas plays: West Virginia Geological and Economic Survey Publication V-25, p. 181-187.

Beinkafner, K.J., 1983, Terminal expression of decollement in Chautauqua County, New York: Northeastern Geology, v. 5, nos. 3-4, p. 160-171.

Berg, T.M., 1999, Devonian-Mississippian transition, chap. 8 of Shultz, C.H., ed., The geology of Pennsylvania: Pennsylvania Geological Survey and Pittsburgh Geological Society Special Publication 1, p. 128-137.

Bjerstedt, T.W., 1986, Regional stratigraphy and sedimentology of the Lower Mississippian Rockwell Formation and Purslane Sandstone based on the new Sideling Hill road cut, Maryland: Southeastern Geology, v. 27, no. 2, p. 69-94.

Bjerstedt, T.W., and Kammer, T.W., 1988, Genetic stratigraphy and depositional systems of the Upper Devonian-Lower Mississippian Price-Rockwell deltaic complex in the central Appalachians, U.S.A.: Sedimentary Geology, v. 54, no. 4, p. 265-301, doi:10.1016/0037-0738(88)90037-1.

Boswell, Ray, 1996, Play UDs; Upper Devonian black shales, in Roen, J.B., and Walker, B.J., eds., The atlas of major Appalachian gas plays: West Virginia Geological and Economic Survey Publication V-25, p. 93-99.

Boswell, R.M., and Donaldson, A.C., 1988, Depositional architecture of the Upper Devonian Catskill delta complex; central Appalachian basin, U.S.A., in McMillan, N.J., Embry, A.F., and Glass, D.J., eds., Devonian of the world; Proceedings of the Second International Symposium on the Devonian System, Calgary, Canada; v. II; Sedimentation: Canadian Society of Petroleum Geologists Memoir 14, p. 65-84.

Boswell, Ray, Heim, L.R., Wrightstone, G.R., and Donaldson, Alan, 1996, Play Dvs; Upper Devonian Venango sandstones and siltstones, in Roen, J.B., and Walker, B.J., eds., The atlas of major Appalachian gas plays: West Virginia Geological and Economic Survey Publication V-25, p. 63-69.

Boswell, R.M., and Jewell, G.A., 1988, Atlas of Upper Devonian/Lower Mississippian sandstones in the subsurface of West Virginia: West Virginia Geological and Economic Survey Circular C-43, 144 p.

Boswell, Ray, Thomas, B.W., Hussing, R.B., Murin, T.M., and Donaldson, Alan, 1996, Play Dbs; Upper Devonian Bradford sandstones and siltstones, in Roen, J.B., and Walker, B.J., eds., The atlas of major Appalachian gas plays: West Virginia Geological and Economic Survey Publication V-25, p. 70-76.
Brezinski, D.K., 1989a, Upper Mississippian depositional patterns in the north-central Appalachian basin, and their implications to Chesterian hierarchal stratigraphy: Southeastern Geology, v. 30, no. 1, p. 1-23.

Brezinski, D.K., 1989b, The Mississippian System in Maryland: Maryland Geological Survey Report of Investigations $52,75 \mathrm{p}$.

Brezinski, D.K., 1999, Mississippian, chap. 9 of Shultz, C.H., ed., The geology of Pennsylvania: Pennsylvania Geological Survey and Pittsburgh Geological Society Special Publication 1, p. 138-147.

Briggs, R.P., and Tatlock, D.B., 1999, Petroleum — Guide to undiscovered natural gas resources, chap. 38C of Shultz, C.H., ed., The geology of Pennsylvania: Pennsylvania Geological Survey and Pittsburgh Geological Society Special Publication 1, p. 530-547.

Bustin, R.M., Ross, Daniel, and Chalmers, Gareth, 2006, Rethinking methodologies of characterizing gas in place in gas shales: American Association of Petroleum Geologists Annual Convention Program, v. 15, p. 16. (Also available online at http://www.searchanddiscovery.com/ documents/2006/06088houston_abs/abstracts/bustin.htm.)

Butts, Charles, 1940, Geology of the Appalachian Valley in Virginia; Part 1, Geologic text and illustrations: Virginia Geological Survey Bulletin 52, 568 p.

Caramanica, F.P., 1988, Oil and gas report and maps of Kanawha and Boone counties, West Virginia: West Virginia Geological and Economic Survey Bulletin B-19A, 115 p., 6 pls.

Carter, K.M., and Flaherty, K.J., 2011, The old, the crude, and the muddy; Oil history in western Pennsylvania, in Ruffalo, R.M., and Ciampaglio, C.N., eds., From the shield to the sea; Geological field trips from the 2011 joint meeting of the GSA Northeastern and North-Central sections: Geological Society of America Field Guide 20, p. 169-185, doi:10.1130/2011.0020(08).

Chadwick, G.H., 1933a, Catskill as a geologic name: American Journal of Science, 5th series, v. 26, p. 479-484, doi:10.2475/ajs.s5-26.155.479.

Chadwick, G.H., 1933b, Great Catskill delta, and revision of late Devonic succession: The Pan-American Geologist, v. 60 , no. 2 , p. $91-107$.

Charpentier, R.R., de Witt, Wallace, Jr., Claypool, G.E., Harris, L.D., Mast, R.F., Megeath, J.D., Roen, J.B., and Schmoker, J.W., 1993, Estimates of unconventional natural gas resources of the Devonian shales of the Appalachian basin, in Roen, J.B., and Kepferle, R.C., eds., Petroleum geology of the Devonian and Mississippian black shale of eastern North America: U.S. Geological Survey Bulletin 
1909-B, p. N1-N20. (Also available online at http://pubs. er.usgs.gov/publication/b1909.)

Coleman, J.L., Milici, R.C., Cook, T.A., Charpentier, R.R., Kirschbaum, Mark, Klett, T.R., Pollastro, R.M., and Schenk, C.J., 2011, Assessment of undiscovered oil and gas resources of the Devonian Marcellus Shale of the Appalachian Basin Province, 2011: U.S. Geological Survey Fact Sheet 2011-3092, 2 p., available only at http://pubs.usgs. gov/fs/2011/3092/.

Colton, G.W., 1970, The Valley and Ridge and Appalachian Plateau; stratigraphy and sedimentation; the Appalachian basin; its depositional sequences and their geologic relationships, in Fisher, G.W., Pettijohn, F.J., Reed, J.C., Jr., and Weaver, K.N., eds., Studies of Appalachian geology, central and southern: New York, N.Y., Interscience Publishers, p. 5-47.

Conant, L.C., and Swanson, V.E., 1961, Chattanooga Shale and related rocks of central Tennessee and nearby areas: U.S. Geological Survey Professional Paper 357, 91 p. (Also available online at http://pubs.er.usgs.gov/publication/ pp357.)

Demaison, G.J., and Moore, G.T., 1980, Anoxic environments and oil source bed genesis: American Association of Petroleum Geologists Bulletin, v. 64, no. 8, p. 1179-1209. (Also available online at http://search.datapages.com/data/ bulletns/1980-81/images/pg/00640008/1150/11790.pdf.)

Denkler, K.E., and Harris, A.G., 1988, Conodont-based determination of Silurian-Devonian boundary in the Valley and Ridge province, northern and central Appalachians: U.S. Geological Survey Bulletin 1837-B, p. B1-B13. (Also available online at http://pubs.er.usgs.gov/publication/ b1837.)

Dennison, J.M., 1985, Catskill delta shallow marine strata, in Woodrow, D.L., and Sevon, W.D., eds., The Catskill delta: Geological Society of America Special Paper 201, p. 91-106.

Dennison, J.M., Beuthin, J.D., and Hasson, K.O., 1986, Latest Devonian-Earliest Carboniferous marine transgressions, central and southern Appalachians, USA: Annales de la Société Géologique de Belgique, v. 109, p. 123-129. (Also available online at $\mathrm{http} / / /$ popups.ulg.ac.be/ASGB/document. php?id=2418.)

Dennison, J.M., Filer, J.K., and Rossbach, T.J., 1996, Devonian strata of southeastern West Virginia and adjacent Virginia, in Dennison, J.M., ed., Geologic field guide to Devonian hydrocarbon stratigraphy of southeastern West Virginia and adjacent Virginia: Charleston, W. Va., Appalachian Geological Society, p. 3-54.

de Witt, Wallace, Jr., 1993, Principal oil and gas plays in the Appalachian basin (Province 131): U.S. Geological Survey
Bulletin 1839-I, 37 p. (Also available online at http://pubs. er.usgs.gov/publication/b1839I.)

de Witt, Wallace, Jr., 1997, Devonian shale gas along Lake Erie's south shore: Northeastern Geology and Environmental Sciences, v. 19, nos. 1-2, p. 34-38.

de Witt, Wallace, Jr., Cohee, G.V., and McGrew, L.W., 1979, Oil and gas in Mississippian rocks in part of the Eastern United States: U.S. Geological Survey Professional Paper 1010-U, p. 441-455. (Also available online at http://pubs. er.usgs.gov/publication/pp1010.)

de Witt, Wallace, Jr., and Milici, R.C., 1991, Petroleum geology of the Appalachian basin, in Gluskoter, H.J., Rice, D.D., and Taylor, R.B., eds., Economic geology, U.S., v. P-2 of The geology of North America: Boulder, Colo., Geological Society of America, p. 273-286.

de Witt, Wallace, Jr., Perry, W.J., Jr., and Wallace, L.G., 1975, Oil and gas data from Devonian and Silurian rocks in the Appalachian basin: U.S. Geological Survey Miscellaneous Investigations Series Map I-917-B, 4 sheets, scale: 1:2,500,000. (Also available online at $h t t p: / / p u b s . e r . u s g s$. gov/publication/i917B.)

de Witt, Wallace, Jr., Roen, J.B., and Wallace, L.G., 1993, Stratigraphy of Devonian black shales and associated rocks in the Appalachian basin, in Roen, J.B., and Kepferle, R.C., eds., Petroleum geology of the Devonian and Mississippian black shale of eastern North America: U.S. Geological Survey Bulletin 1909-B, p. B1-B57. (Also available online at http://pubs.er.usgs.gov/publication/b1909.)

Donaldson, Alan, Boswell, Ray, Zou, Xiangdong, Cavallo. Larry, Heim, L.R., and Canich, Michael, 1996, Play Des; Upper Devonian Elk sandstones and siltstones, in Roen, J.B., and Walker, B.J., eds., The atlas of major Appalachian gas plays: West Virginia Geological and Economic Survey Publication V-25, p. 77-85.

Drozd, R.J., and Cole, G.A., 1994, Point Pleasant-Brassfield(!) petroleum system, Appalachian basin, U.S.A., in Magoon, L.B., and Dow, W.G., eds., The petroleum system-From source to trap: American Association of Petroleum Geologists Memoir 60, p. 387-398. (Also available online at http://search.datapages.com/data/specpubs/methodo2/data/ a077/a077/0001/0350/0387.htm.)

East, J.A., Swezey, C.S., Repetski, J.E., and Hayba, D.O., 2012, Thermal maturity map of Devonian shale in the Illinois, Michigan, and Appalachian basins of North America: U.S. Geological Survey Scientific Investigations Map 3214, 1 sheet. (Also available at http://pubs.usgs.gov/sim/3214/.)

Engelder, Terry, 2009, Marcellus 2008; Report card on the breakout year for gas production in the Appalachian basin: Fort Worth Basin Oil \& Gas Magazine, August 2009, p. 18-22. (Also available online at http://www.marcellus. psu.edu/resources/PDFs/marcellusengelder.pdf.) 
Engelder, Terry, and Lash, G.G., 2008, Marcellus Shale play's vast resource potential creating stir in Appalachia: American Oil and Gas Reporter, May 2008, 7 p. (Also available online at http://www.aogr.com/index.php/magazine/cover-story/ marcellus-shale-plays-vast-resource-potential-creating-stirin-appalachia.)

Ettensohn, F.R., 1985a, Controls on development of Catskill delta complex basin-facies, in Woodrow, D.L., and Sevon, W.D., eds., The Catskill delta: Geological Society of America Special Paper 201, p. 65-77.

Ettensohn, F.R., 1985b, The Catskill delta complex and the Acadian orogeny; a model, in Woodrow, D.L., and Sevon, W.D., eds., The Catskill delta: Geological Society of America Special Paper 201, p. 39-49.

Ettensohn, F.R., 2008, The Appalachian foreland basin in eastern United States, in Miall, A.D., ed., The sedimentary basins of the United States and Canada, v. 5 of Sedimentary basins of the world: Amsterdam, The Netherlands, Elsevier, p. 105-179, doi:10.1016/S1874-5997(08)00022-1.

Ettensohn, F.R., and Barron, L.S., 1981, Depositional model for the Devonian-Mississippian black shales of North America-A paleoclimate-paleogeographic approach, in Roberts, T.G., ed. Field trip guidebooks for the annual meeting of the Geological Society of America, 1981, Cincinnati, Ohio, v. 2-Economic geology, structure: Falls Church, Va., American Geological Institute, p. 344-361.

Ettensohn, F.R., and Barron, L.S., 1982, A tectonic-climatic approach to the deposition of the Devonian-Mississippian black-shale sequence of North America, in Appalachian Industrial Associates, Program - Fall Meeting, October 14-15, 1982: Blacksburg, Va., Virginia Polytechnic Institute and State University, p. 161-249.

Faill, R.T., 1985, The Acadian orogeny and the Catskill delta, in Woodrow, D.L., and Sevon, W.D., eds., The Catskill delta: Geological Society of America Special Paper 201, p. 15-37.

Faill, R.T., 1997, A geologic history of the north-central Appalachians; Part 2, The Appalachian basin from the Silurian through the Carboniferous: American Journal of Science, v. 297 , no. 7, p. 729-761, doi:10.2475/ajs.297.7.729.

Filer, J.K., 1985, Oil and gas report and maps of Pleasants, Wood, and Ritchie Counties, West Virginia: West Virginia Geological and Economic Survey, Bulletin B-11A, 87 p.

Filer, J.K., 1994, High frequency eustatic and siliciclastic sedimentation cycles in a foreland basin, Upper Devonian, Appalachian basin, in Dennison, J.M., and Ettensohn, F.R., eds., Tectonic and eustatic controls on sedimentary cycles: Concepts in Sedimentology and Paleontology, v. 4, p. 133-145, doi:10.2110/csp.94.04.0133.
Filer, J.K., 2002, Late Frasnian sedimentation cycles in the Appalachian basin - Possible evidence for high frequency eustatic sea-level changes: Sedimentary Geology, v. 154, nos. 1-2, p. 31-52, doi:10.1016/S0037-0738(02)00159-8.

Filer, J.K., 2003, Stratigraphic evidence for a Late Devonian possible back-bulge basin in the Appalachian basin, United States: Basin Research, v. 15, no. 3, p. 417-429, doi:10.1046/j.1365-2117.2003.00213.x.

Filer, J.K., Dennison, J.M., and Warne, A.G., 1996, Composite Devonian and Lower Mississippian section near Norton, Virginia: Virginia Division of Mineral Resources Publication 145, 2 sheets. (Also available at http://www.dmme. virginia.gov/commercedocs/PUB_145.pdf.)

Frey, M.G., 1973, Influence of Salina salt on structure in New York-Pennsylvania part of Appalachian Plateau: American Association of Petroleum Geologists Bulletin, v. 57, no. 6, p. 1027-1037. (Also available online at http:// search.datapages.com/data/bulletns/1971-73/images/ pg/00570006/1000/10270.pdf.)

Gautier, D.L., Dolton, G.L., Attanasi, E.D., comps., 1998, 1995 National oil and gas assessment and onshore Federal lands: U.S. Geological Survey Open-File Report 95-75-N, 64 p. (Also available online at http://pubs.er.usgs.gov/ publication/ofr9575N.)

Gautier, D.L., Dolton, G.L., Takahashi, K.I., and Varnes, K.L., eds., 1995, 1995 National Assessment of United States oil and gas resources - Results, methodology, and supporting data: U.S. Geological Survey Digital Data Series 30, 1 CD-ROM.

Harland, W.B., Armstrong, R.L., Cox, A.V., Craig, L.E., Smith, A.G., and Smith, D.G., 1990, A geologic time scale: Cambridge, United Kingdom, Cambridge University Press, $263 \mathrm{p}$.

Harper, J.A., 1999, Devonian, chap. 7 of Shultz, C.H., ed., The geology of Pennsylvania: Pennsylvania Geological Survey and Pittsburgh Geological Society Special Publication 1, p. $108-127$.

Harris, L.D., and Milici, R.C., 1977, Characteristics of thinskinned style of deformation in the southern Appalachians, and potential hydrocarbon traps: U.S. Geological Survey Professional Paper 1018, 40 p., 9 pls. (Also available online at http://pubs.er.usgs.gov/publication/pp1018.)

Hasson, K.O., and Dennison, J.M., 1988, Devonian shale lithostratigraphy, central Appalachians, U.S.A., in McMillan, N.J., Embry, A.F., and Glass, D.J., eds., Devonian of the world; Proceedings of the Second International Symposium on the Devonian System, Calgary, Canada; v. II; Sedimentation: Canadian Society of Petroleum Geologists Memoir 14, p. $157-177$. 
Hayes, C.W., 1891, The overthrust faults of the southern Appalachians, with discussion by C.D. Walcott, W.M. Davis, and Bailey Willis: Geological Society of America Bulletin, v. 2, p. 141-154.

Ibach, L.E.J., 1982, Relationship between sedimentation rate and total organic carbon content in ancient marine sediments: American Association of Petroleum Geologists Bulletin, v. 66, no. 2, p. 170-188. (Also available online at http://search.datapages.com/data/bulletns/1982-83/images/ pg/00660002/0150/01700.pdf.)

Johnson, J.G., Klapper, Gilbert, and Sandberg, C.A., 1985, Devonian eustatic fluctuations in Euramerica: Geological Society of America Bulletin, v. 96, no. 5, p. 567-587, doi:10.1130/0016-7606(1985)96<567:DEFIE $>2.0 . C O ; 2$.

Kammer, T.W., and Bjerstedt, T.W., 1986, Stratigraphic framework of the Price Formation (Upper Devonian-Lower Mississippian) in West Virginia: Southeastern Geology, v. 27 , no. 1, p. 13-33.

Kane, Tom, 2008, Marcellus Shale is bigger than estimated: The River Reporter, v. 34, no. 47, available only online at http://www.riverreporter.com/issues/08-11-20/news-shale. html. (Accessed April 11, 2012.)

Kendrick, Daniel, 2009, Horizontal well stimulation; what we know and what to look for; Workshop 5, Indiana Oil and Gas Association Annual Dinner Meeting and Expo, Evansville, Ind., October 2, 2009: Indiana Oil and Gas Association Web page at http://www.inoga.org/ archive/2009/Workshop5.pdf. (Accessed April 11, 2012.)

Kepferle, R.C., 1993, A depositional model and basin analysis for the gas-bearing black shale (Devonian and Mississippian) in the Appalachian basin, in Roen, J.B., and Kepferle, R.C., eds., Petroleum geology of the Devonian and Mississippian black shale of eastern North America: U.S. Geological Survey Bulletin 1909, p. F1-F23. (Also available online at http://pubs.er.usgs.gov/publication/b1909.)

Kuuskraa, V.A., Sedwick, K.B., Thompson, K.B., and Wicks, D.E., 1985, Technically recoverable Devonian shale gas in Kentucky: U.S. Department of Energy Morgantown Energy Technology Center Report DOE/MC/19239-1834 (DE85008608), $120 \mathrm{p}$.

Kuuskraa, V.A., and Wicks, D.E., 1984, Technically recoverable Devonian shale gas in West Virginia: U.S. Department of Energy Morgantown Energy Technology Center Report DOE/MC/19239-1750 (DE85003367), 119 p.

Langbein, W.B., and Schumm, S.A., 1958, Yield of sediment in relation to mean annual precipitation: Transactions American Geophysical Union, v. 39, no. 6, p. 1076-1084.

Leone, James, and Smith, Langhorne, 2011, Vertical and lateral extent and TOC content of Middle and Upper Devonian organic-rich shales, New York State [abs.], in Proceedings, 40th Eastern Section Meeting, American Association of Petroleum Geologists, Arlington, Va., September 24-29, 2011: Tulsa, Okla., American Association of Petroleum Geologists, p. 39.

Lewin and Associates, Inc., 1983, Technically recoverable Devonian shale gas in Ohio: U.S. Department of Energy Morgantown Energy Technology Center Report DOE/ MC/19239-1525 (DE84003057), 101 p. (Also available online at http://www.osti.gov/energycitations/product.biblio. jsp?osti_id=5357761.)

Lo, H.B., 1993, Correction criteria for suppression of vitrinite reflectance in hydrogen-rich kerogens; preliminary guidelines: Organic Geochemistry, v. 20, no. 6, p. 653-657, doi:10.1016/0146-6380(93)90051-C.

Lundegard, P.D., Samuels, N.D., and Pryor, W.D., 1985, Upper Devonian turbidite sequence, central and southern Appalachian basin; contrasts with submarine fan deposits, in Woodrow, D.L., and Sevon, W.D., eds., The Catskill delta: Geological Society of America Special Paper 201, p. 107-121.

Magoon, L.B., and Dow, W.G., eds., 1994, The petroleum system-From source to trap: American Association of Petroleum Geologists Memoir 60, 655 p.

Markowski, A.K., 2001, Reconnaissance of the coal-bed methane resources in Pennsylvania: Pennsylvania Bureau of Topographic and Geologic Survey Mineral Resources Report 95, 134 p.

Matchen, D.L., and Vargo, A.G., 1996, Play Mws; Lower Mississippian Weir sandstones, in Roen, J.B., and Walker, B.J., eds., The atlas of major Appalachian gas plays: West Virginia Geological and Economic Survey Publication V-25, p. 46-50.

Maynard, J.B., 1981, Some geochemical properties of the Devonian-Mississippian shale sequence, in Kepferle, R.C., and Roen, J.B., eds., Field Trip no. 3, Chattanooga and Ohio Shales of the southern Appalachians, in Roberts, T.G., ed., Field trip guidebooks for the annual meeting of the Geological Society of America, 1981, Cincinnati, Ohio, v. 2, Economic Geology, Structure: Falls Church, American Geological Institute, p. 336-343.

Milici, R.C., 1980, Relationship of regional structure to oil and gas producing areas in the Appalachian basin: U.S. Geological Survey Miscellaneous Investigations Series Map I-917-F, scale 1:2,500,000.

Milici, R.C., 1993, Autogenic gas (self-sourced) from shalesAn example from the Appalachian basin, in Howell, D.G., ed., The future of energy gases: U.S. Geological Survey Professional Paper 1570, p. 253-278. (Also available online at http://pubs.er.usgs.gov/publication/pp1570.) 
Milici, R.C., 1995, Devonian black shale gas plays, in Ryder, R.T., Appalachian basin province (067), in Gautier, D.L., Dolton, G.L., Takahashi, K.I., and Varnes, K.L., 1995 National assessment of United States oil and gas resources-Results, methodology, and supporting data: U.S. Geological Survey Digital Data Series DDS-30, p. 57-63, 1 CD-ROM.

Milici, R.C., 1996a, Play Dbg; Upper Devonian fractured black and gray shales and siltstones, in Roen, J.B., and Walker, B.J., eds., The atlas of major Appalachian gas plays: West Virginia Geological and Economic Survey Publication V-25, p. 86-92.

Milici, R.C., 1996b, Play Mfp; The Lower Mississippian Fort Payne carbonate mound play, in Roen, J.B., and Walker, B.J., eds., The atlas of major Appalachian gas plays: West Virginia Geological and Economic Survey Publication V-25, p. 51-55.

Milici, R.C., 1996c, Stratigraphic history of the Appalachian basin, in Roen, J.B., and Walker, B.J., eds., The atlas of major Appalachian gas plays: West Virginia Geological and Economic Survey Publication V-25, p. 4-7.

Milici, R.C., and de Witt, Wallace, Jr., 1988, The Appalachian basin, in Sloss, L.L., ed., Sedimentary cover; North American craton; U.S., v. D-2 of The geology of North America: Boulder, Colo., Geological Society of America, p. 427-469.

Milici, R.C., and Gathright, T.M., II, 1983, Fracture porosity and hydrocarbon potential of the Valley and Ridge of southwestern Virginia and adjacent Tennessee, in Luther, M.K., Proceedings of the technical sessions, Kentucky Oil and Gas Association Forty-Third Annual Meeting, June 13-15, 1979: Kentucky Geological Survey Special Publication 7, p. $89-96$.

Milici, R.C., and Roen, J.B., 1981, Stratigraphy of the Chattanooga Shale in the Newman Ridge and Clinch Mountain areas, Tennessee: Tennessee Division of Geology Report of Investigations 40, $102 \mathrm{p}$.

Milici, R.C., Ryder, R.T., Swezey, C.S., Charpentier, R.R., Cook, T.A, Crovelli, R.A., Klett, T.R., Pollastro, R.M., and Schenk, C.J., 2003, Assessment of undiscovered oil and gas resources of the Appalachian Basin Province, 2002: U.S. Geological Survey Fact Sheet 009-03, 2 p. (Also available at http://pubs.usgs.gov/fs/fs-009-03/.)

Milici, R.C. and Statler, A.T., 1980, Fractures related to major thrusts - Possible analogues to tectonically fractured Chattanooga Shale in Tennessee, in Wheeler, R.L., and Dean, C.S., eds., Proceedings, Western limits of detachment and related structures in the Appalachian foreland, Southeastern section, Geological Society of America, Chattanooga, Tenn., April 6, 1978: U.S. Department of Energy Morgantown Energy Technology Center DOE/METC/SP-80/23, p. 157-166. (Also available online at http://www.netl. doe.gov/kmd/cds/disk7/disk1/EGS\%5CProceedings, $\% 20$ Western\%20Limits\%20of\%20Detachment $\% 20 \& \% 20$ Related\%20Structur.pdf.)

Milici, R.C., and Swezey, C.S., 2006, Assessment of Appalachian basin oil and gas resources; Devonian Shale-Middle and Upper Paleozoic Total Petroleum System: U.S. Geological Survey Open-File Report 2006-1237, 70 p., figures and tables as separate files, available only online at http://pubs. usgs.gov/of/2006/1237/.

Murphy, D.C., 2006, The first forests, in Devonian Times (4th ed.): Devonian Times Web page at http://www. devoniantimes.org/opportunity/forests.html. (Accessed February 29, 2012.)

Nuttall, B.C., 1996, Play Obc; Middle and Upper Ordovician bioclastic carbonate ("Trenton") play, in Roen, J.B., and Walker, B.J., eds., The atlas of major Appalachian gas plays: West Virginia Geological and Economic Survey Publication V-25, p. 168-171.

Oliver, W.A., Jr., de Witt, Wallace, Jr., Dennison, J.M., Hoskins, D.M., and Huddle, J.W., 1967, Devonian of the Appalachian basin, United States, in Oswald, D.H., ed., International Symposium on the Devonian System: Calgary, Alberta, Canada, Alberta Society of Petroleum Geologists, p. 1001-1040.

Oliver, W.A., Jr., de Witt, Wallace, Jr., Dennison, J.M., Hoskins, D.M., and Huddle, J.W., 1971, Isopach and lithofacies maps of the Devonian in the Appalachian basin: Pennsylvania Bureau of Topographic and Geologic Survey Progress Report 182, 7 sheets, scale 1:1,204,000.

Over, D.J., 2002, The Frasnian/Famennian boundary in central and eastern United States: Palaeogeography, Palaeoclimatology, Palaeoecology, v. 181, nos. 1-3, p. 153-159, doi:10.1016/S0031-0182(01)00477-1.

Patchen, D.G., and Hohn, M.E., 1993, Production and production controls in Devonian shales, West Virginia, in Roen, J.B., and Kepferle, R.C., eds., Petroleum geology of the Devonian and Mississippian black shale of eastern North America: U.S. Geological Survey Bulletin 1909-B, p. L1-L28. (Also available online at http://pubs.er.usgs.gov/ publication/b1909.)

Patchen, D.G., Avary, K.L., and Erwin, R.B., comps., 1985a, Correlation of stratigraphic units of North America (COSUNA) - Northern Appalachian region: Tulsa, Ola., American Association of Petroleum Geologists, 1 sheet.

Patchen, D.G., Avary, K.L., and Erwin, R.B., comps., 1985b, Correlation of stratigraphic units of North America (COSUNA) - Southern Appalachian region: Tulsa, Okla., American Association of Petroleum Geologists, 1 sheet. 
Patenaude, M.W., Beardsley, R.W., and Campbell, R.C., 1986, Onondaga-Bass Island trend-Salt detachment structure in western New York [abs.]: American Association of Petroleum Geologists Bulletin, v. 70, no. 5, p. 629. (Also available online at http://searchanddiscovery.com/abstracts/ html/1986/annual/abstracts/0629b.htm.)

Pederson, T.F., and Calvert, S.E., 1990, Anoxia vs. productivity-What controls the formation of organic-carbon-rich sediments and sedimentary rocks?: American Association of Petroleum Geologists Bulletin, v. 74, no. 4, p. 454-466. (Also available online at http://search.datapages.com/data/ bulletns/1990-91/data/pg/0074/0004/0000/0454.htm.)

Pederson, T.F., and Calvert, S.E., 1991, Anoxia vs. productivity - What controls the formation of organiccarbon-rich sediments and sedimentary rocks? Reply: American Association of Petroleum Geologists Bulletin, v. 75, no. 3, p. 500-501. (Also available online at http://search.datapages.com/data/bulletns/1990-91/data/ pg/0075/0003/0000/0500.htm.)

Piotrowski, R.G., and Harper, J.A., 1979, Black shale and sandstone facies of the Devonian "Catskill" clastic wedge in the subsurface of western Pennsylvania: U.S. Department of Energy Morgantown Energy Technology Center Eastern Gas Shales Project Series 13, 40 p., 39 pls.

Piotrowski, R.G., and Krajewski, S.A., 1977, Preliminary stratigraphic cross section $\left(\mathrm{C}_{1}-\mathrm{C}_{3}\right)$ showing radioactive black shale zones and sandstones in the Middle and Upper Devonian, western Pennsylvania: U.S. Department of Energy Morgantown Energy Technology Center Eastern Gas Shales Project Series 1, 2 sheets.

Repetski, J.E., Ryder, R.T., Avary, K.L., and Trippi, M.H., 2005, Thermal maturity patterns (CAI and $\% \mathrm{R}_{\mathrm{o}}$ ) in the Ordovician and Devonian rocks of the Appalachian basin in West Virginia: U.S. Geological Survey Open-File Report 2005-1078, 72 p., tables. (Also available online at http:// pubs.usgs.gov/of/2005/1078/.)

Repetski, J.E., Ryder, R.T., Harper, J.A., and Trippi, M.H., 2002, Thermal maturity patterns (CAI and $\% \mathrm{R}_{\mathrm{o}}$ ) in the Ordovician and Devonian rocks of the Appalachian basin in Pennsylvania: U.S. Geological Survey Open-File Report 02-302, 57 p., available only online at http://pubs.usgs.gov/ of/2002/of02-302/.

Repetski, J.E., Ryder, R.T., Weary, D.J., Harris, A.G., and Trippi, M.H., 2008, Thermal maturity patterns (CAI and $\% \mathrm{R}_{\mathrm{o}}$ ) in Upper Ordovician and Devonian rocks of the Appalachian basin; a major revision of USGS Map I-917-E using new subsurface collections: U.S. Geological Survey Scientific Investigations Map 3006, 1 CD-ROM. (Also available online at http://pubs.usgs.gov/sim/3006/.)
Roen, J.B., and Kepferle, R.C., eds., 1993, Petroleum geology of the Devonian and Mississippian black shale of eastern North America: U.S. Geological Survey Bulletin 1909, 432 p. (Also available online at http://pubs.er.usgs.gov/ publication/b1909.)

Roen, J.B., and Walker, B.J., eds., 1996, The atlas of major Appalachian gas plays: West Virginia Geological and Economic Survey Publication V-25, 201 p.

Rowan, E.L., 2006, Burial and thermal history of the central Appalachian basin, based on three 2-D models of Ohio, Pennsylvania, and West Virginia: U.S. Geological Survey Open-File Report 2006-1019, 35 p., available only online at http://pubs.usgs.gov/of/2006/1019/.

Rowan, E.L., Ryder, R.T., Repetski, J.E., Trippi, M.H., and Ruppert, L.F., 2004, Initial results of a 2D burial/thermal history model, central Appalachian basin, Ohio and West Virginia: U.S. Geological Survey Open-File Report 2004 1445, 28 p. (Also available online at http://pubs.usgs.gov/ of $/ 2004 / 1445 /$.)

Rowan, E.L., Ryder, R.T., Swezey, C.S., Repetski, J.E., Crangle, R.D., Trippi, M.H., and Ruppert, L.F., 2004, Burial/thermal history and hydrocarbon generation model of a cross-section through the north-central Appalachian basin, Ohio and West Virginia: Geological Society of America, Abstracts with Programs, v. 36, no. 2, p. 147. (Also available at http://gsa.confex.com/gsa/2004NE/finalprogram/ abstract_69047.htm.)

Ruppert, L.F., Hower, J.C., Ryder, R.T., Levine, J.R., Trippi, M.H., and Grady, W.C., 2010, Geologic controls on thermal maturity patterns in Pennsylvanian coal-bearing rocks in the Appalachian basin: International Journal of Coal Geology, v. 81, no. 3, p. 169-181, doi:10.1016/j.coal.2009.12.008.

Russell, D.J., 1993, Stratigraphy of the Kettle Point Formation (Upper Devonian of southwestern Ontario, Canada) Implications for depositional setting and resource potential, in Roen, J.B. and Kepferle, R.C., eds., Petroleum geology of the Devonian and Mississippian black shale of eastern North America: U.S. Geological Survey Bulletin 1909-E, p. E1-E11. (Also available online at http://pubs.er.usgs.gov/ publication/b1909.)

Ryder, R.T., Burruss, R.C., and Hatch, J.R., 1998, Black shale source rocks and oil generation in the Cambrian and Ordovician of the central Appalachian basin, USA: American Association of Petroleum Geologists Bulletin, v. 82, no. 3, p. 412-441. (Also available online at http://archives. datapages.com/data/bulletns/1998/03mar/0412/0412.htm.)

Ryder, R.T., Swezey, C.S., Crangle, R.D., Jr., and Trippi, M.H., 2008, Geologic cross section $E-E^{\prime}$ through the Appalachian basin from the Findlay arch, Wood County, Ohio, to the Valley and Ridge province, Pendleton County, West 
Virginia: U.S. Geological Survey Scientific Investigations Map 2985. (Also available online at http://pubs.usgs.gov/ $\operatorname{sim} / 2985 /$.)

Sanford, B.V., 1993, St. Lawrence platform-Economic geology, in Stott, D.F., and Aitken, J.D., eds., Sedimentary cover of the craton in Canada, v. D-1 of The geology of North America: Boulder, Colo., Geological Society of America, p. 787-798.

Schieber, Jürgen, 1998, Developing a sequence stratigraphic framework for the Late Devonian Chattanooga Shale of the southeastern U.S.A.; relevance for the Bakken Shale, in Christopher, J.E., Gilboy, C.F., Paterson, D.F., and Bend, S.L., eds., Eighth International Williston Basin Symposium: Saskatchewan Geological Society Special Publication 13, p. 58-68. (Also available online at http://www.indiana. edu/ sepm04/PDF/JS-B14-WBS_Bakken.pdf.).

Schmoker, J.W., 1993, Use of formation density logs to determine organic-carbon content in Devonian shales of the western Appalachian basin and an additional example based on the Bakken Formation of the Williston basin, in Roen, J.B., and Kepferle, R.C., eds., Petroleum geology of the Devonian and Mississippian black shale of eastern North America: U.S. Geological Survey Bulletin 1909-B, p. J1-J14. (Also available online at http://pubs.er.usgs.gov/ publication/b1909.)

Schmoker, J.W., 1999, U.S. Geological Survey assessment model for continuous (unconventional) oil and gas accumulations - The "FORSPAN" model: U.S. Geological Survey Bulletin 2168, 9 p., available only online at http://pubs.usgs. gov/bul/b2168/.

Schmoker, J.W., 2002, Resource-assessment perspectives for unconventional gas systems: American Association of Petroleum Geologists Bulletin, v. 86, no. 11, p. 1993-1999. (Also available at http://archives.datapages.com/data/ bulletns/2002/11nov/1993/1993.htm.)

Sessa, J.A., 2003, The dynamics of rapid, asynchronous biotic turnover in the Middle Devonian Appalachian basin of New York: Cincinnati, Ohio, University of Cincinnati, unpublished M.S. thesis, $80 \mathrm{p}$.

Sevon, W.D., 1985, Nonmarine facies of the Middle and Late Devonian Catskill coastal alluvial plain, in Woodrow, D.L., and Sevon, W.D., eds., The Catskill delta: Geological Society of America Special Paper 201, p. 79-90.

Shumaker, R.C., 1980, Porous fracture facies in the Devonian shales of eastern Kentucky and West Virginia, in Wheeler, R.L., and Dean, C.S., eds., Proceedings, Western limits of detachment and related structures in the Appalachian foreland, Southeastern section, Geological Society of America, Chattanooga, Tenn., April 6, 1978: U.S. Department of Energy Morgantown Energy Technology Center DOE/ METC/SP-80/23, p. 124-32.
Shumaker, R.C., 1993, Structural parameters that affect Devonian shale gas production in West Virginia and eastern Kentucky, in Roen, J.B., and Kepferle, R.C., eds., Petroleum geology of the Devonian and Mississippian black shale of eastern North America: U.S. Geological Survey Bulletin 1909-B, p. K1-K38. (Also available online at http://pubs. er.usgs.gov/publication/b1909.)

Shumaker, R.C., 1996, Structural history of the Appalachian basin, in Roen, J.B., and Walker, B.J., 1996, The atlas of major Appalachian gas plays: West Virginia Geological and Economic Survey Publication V-25, p. 8-21.

Sloss, L.L., 1988, Tectonic evolution of the craton in Phanerozoic time, in Sloss, L.L., ed., Sedimentary coverNorth American craton, v. D-2 of The geology of North America: Boulder, Colo., Geological Society of America, p. $25-51$.

Soeder, D.J., Randolph, P.L., and Matthews, R.D., 1986, Porosity and permeability of eastern Devonian gas shale: U.S. Department of Energy Morgantown Energy Technology Center DOE/MC20342-8, 117 p. (Also available online at http://www.netl.doe.gov/kmd/cds/disk7/disk1/ EGS\%5CPorosity\%20and\%20Permeability\%20of\%20 Eastern\%20Devonian\%20Gas\%20Shale\%20(Top.pdf.)

Streib, D.L., 1981, Distribution of gas, organic carbon, and vitrinite reflectance in the eastern Devonian gas shales and their relationship to the geologic framework: U.S. Department of Energy, Morgantown Energy Technology Center Report DOE/MC/08216-1276, 273 p.

Sweeney, J., 1986, Oil and gas report and maps of Wirt, Roane, and Calhoun Counties, West Virginia: West Virginia Geological and Economic Survey Bulletin B-40, 102 p., 9 pls., scale 1:62,500.

Swezey, C.S., 2002, Regional stratigraphy and petroleum systems of the Appalachian basin, North America: U.S. Geological Survey Geological Investigations Series Map I-2768, one sheet. (Also available as version 1.0 at http:// pubs.usgs.gov/imap/i-2768/.)

Taylor, G.H., Teichmuller, M., Davis, A., Diessel, C.F.K., Littke, R., and Robert, P., 1998, Organic petrology; a new handbook incorporating some revised parts of Stach's textbook of coal petrology: Berlin, Federal Republic of Germany, Gebruder Borntraeger, 720 p.

Tetra Tech, Inc., 1981, Evaluation of the eastern gas shales in Pennsylvania: U.S. Department of Energy, Morgantown Energy Technology Center Report DOE/METC-119, 89 p., 1 pl., scale 1:1,100,000. (Also available online at http:// www.osti.gov/scitech/biblio/6047507.)

Tissot, B.P., and Welte, D.H., 1984, Petroleum formation and occurrence: Berlin, Federal Republic of Germany, SpringerVerlag, $699 \mathrm{p}$. 
Tomastik, T.E., 1996, Play MDe; Lower Mississippian-Upper Devonian Berea and equivalent sandstones, in Roen, J.B., and Walker, B.J., eds., The atlas of major Appalachian gas plays: West Virginia Geological and Economic Survey Publication V-25, p. 56-62.

U.S. Department of Energy, National Energy Technology Laboratory, 2007, DOE's unconventional gas research programs 1976-1995; An archive of important results: Morgantown, W. Va., U.S. Department of Energy National Energy Technology Laboratory, Natural Gas Program archive disks 1 and 2. (Also available at: http://www.netl.doe.gov/KMD/ cds/disk7/disk1/frontend.pdf and http://www.netl.doe.gov/ $\mathrm{KMD} / \mathrm{cds} /$ disk $7 /$ disk2/frontend.pdf.)

U.S. Department of the Interior, 1976, Success at Oil Creek: Washington, D.C., U.S. Department of Interior, 16 p.

Van Tyne, A.M., 1996, Play SBi; Upper Silurian Bass Islands trend, in Roen, J.B., and Walker, B.J., eds., The atlas of major Appalachian gas plays: West Virginia Geological and Economic Survey Publication V-25, p. 130-132.

Vargo, A.G., and Matchen, D.L., 1996, Play Mbi; Lower Mississippian Big Injun sandstones, in Roen, J.B., and Walker, B.J., eds., The atlas of major Appalachian gas plays: West Virginia Geological and Economic Survey Publication V-25, p. 41-45.

Weary, D.J., Ryder, R.T., and Nyahay, Richard, 2000, Thermal maturity patterns (CAI and $\% \mathrm{R}_{\mathrm{o}}$ ) in the Ordovician and Devonian of the Appalachian basin in New York State: U.S. Geological Survey Open-File Report 00-496, 39 p. (Also available online at http://pubs.usgs.gov/of/2000/of00-496/.)

Weary, D.J., Ryder, R.T., and Nyahay, R.E., 2001, Thermal maturity patterns in New York State using CAI and $\% \mathrm{R}_{\mathrm{o}}$ : Northeastern Geology and Environmental Sciences, v. 23, no. 4, p. 356-376.
Weeks, J.D., 1886, Natural gas, in Day, D.T., ed., Mineral resources of the United States; calendar year 1885: Washington, D.C., U.S. Geological Survey, p. 155-179. (Also available at http://archive.org/details/ mineralresources1885unit.)

Wickstrom, L.H., 1996, Play MOf; Middle Ordovician fractured carbonates, in Roen, J.B., and Walker, B.J., eds., 1996, The atlas of major Appalachian gas plays: West Virginia Geological and Economic Survey Publication V-25, p. 172-176.

Woodrow, D.L., Dennison, J.M., Ettensohn, F.R., Sevon, W.T., and Kirchgasser, W.T., 1988, Middle and Upper Devonian stratigraphy and paleogeography of the central and southern Appalachians and eastern midcontinent, U.S.A., in McMillan, N.J., Embry, A.F., and Glass, D.J., eds., Devonian of the world; Proceedings of the Second International Symposium on the Devonian System, Calgary, Canada; v. 1; Regional synthesis: Canadian Society of Petroleum Geologists Memoir 14, p. 277-301.

Wrightstone, Gregory, 2009, Marcellus Shale-Geologic controls on production: American Association of Petroleum Geologists Search and Discovery article 10206, available only online at http://www.searchanddiscovery.net/documents/ 2009/10206wrightstone/. (Accessed on April 13, 2012.)

Young, D.M., 1957, Deep drilling through Cumberland overthrust block in southwestern Virginia: American Association of Petroleum Geologists Bulletin, v. 41, no. 11, p. 25672573. (Also available online at http://search.datapages.com/ data/bulletns/1957-60/data/pg/0041/0011/2550/2567.htm.)

Zielinski, R.E., and McIver, R.D., 1982, Resource and exploration assessment of the oil and gas potential in the Devonian shales of the Appalachian basin: U.S. Department of Energy, Morgantown Energy Technology Center Report DOE/DP/0053-1125, MLM-MU-82-61-0002, 423 p. 

Figures 1-37 and Tables 1-4 




Base from U.S. Geological Survey digital data, 2001, $1: 2,000,000$

Albers Equal Area Conic projection

Standard parallels $29^{\circ} 30^{\prime} \mathrm{N}$ and $45^{\circ} 30^{\prime} \mathrm{N}$ 
Figure 1 (facing page). Map showing the location of the Appalachian Basin Petroleum Province and the location of the Drake oil well. In 2002, the U.S. Geological Survey assessed the undiscovered oil and gas resources of the United States' portion of this province (Milici and others, 2003). 





Figure 2 (facing page). Map showing the extent of the the Devonian Shale-Middle and Upper Paleozoic Total Petroleum System (TPS) within the Appalachian Basin Petroleum Province. The green, yellow, and gray areas represent the extent of the Devonian and Lower Mississippian shale. The yellow area represents the extent of thermally immature source rocks, and the green area represents the extent of thermally mature source rocks. The mature source rocks (green) of this TPS are of Devonian age. The gray areas were not assessed. Additional data on thermal maturity of the Devonian shale may be found in East and others (2012). 


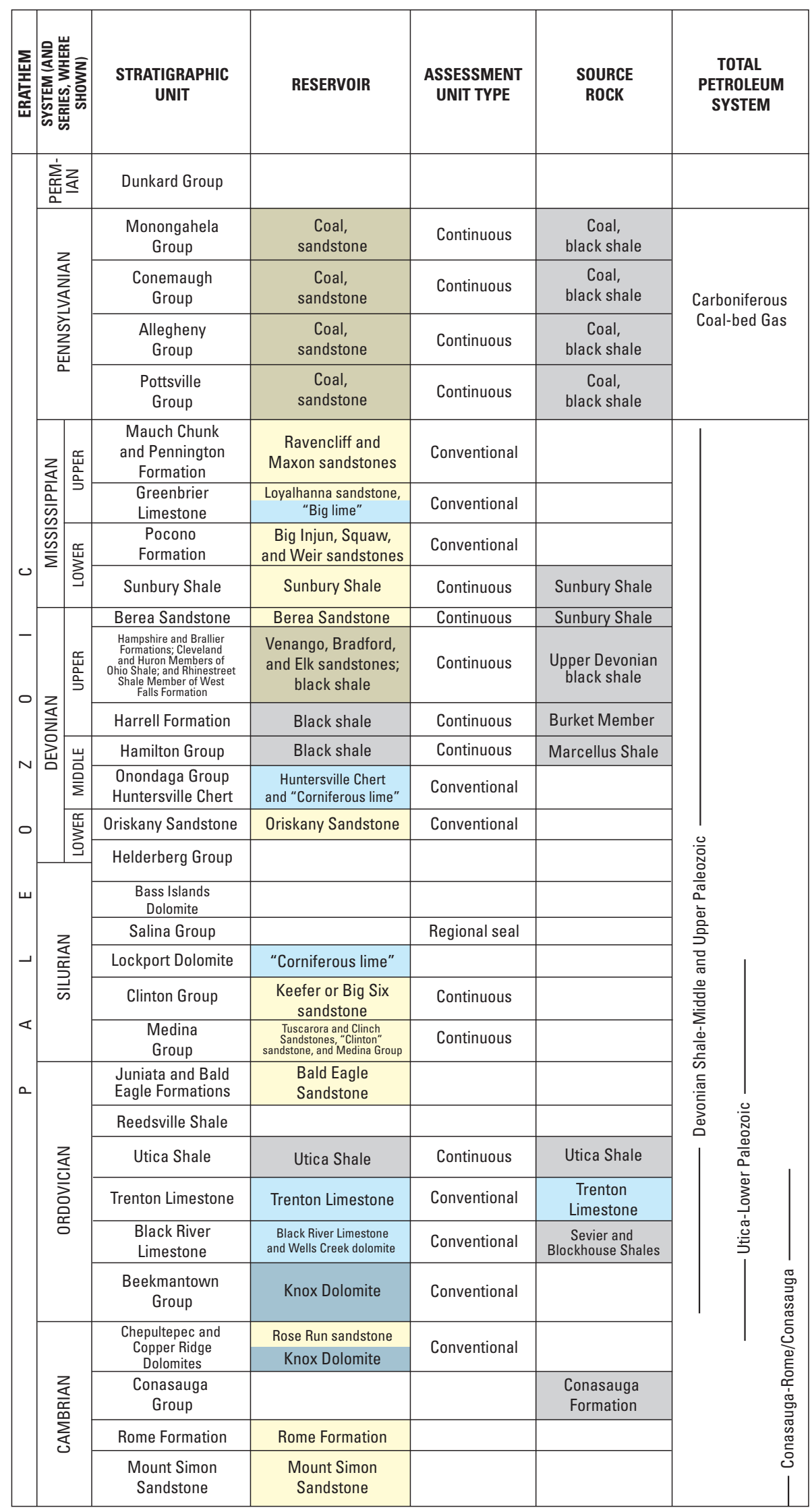

\section{EXPLANATION}

Predominant lithology of source or reservoir rock

Coal, black shale, and (or) sandstone Black shale and (or) coal

\section{Sandstone}

Limestone

Dolomite

Figure 3. Chart showing the generalized stratigraphy of the Appalachian Basin Petroleum Province and total petroleum system data (adapted from de Witt and Milici, 1991, fig. 2). 


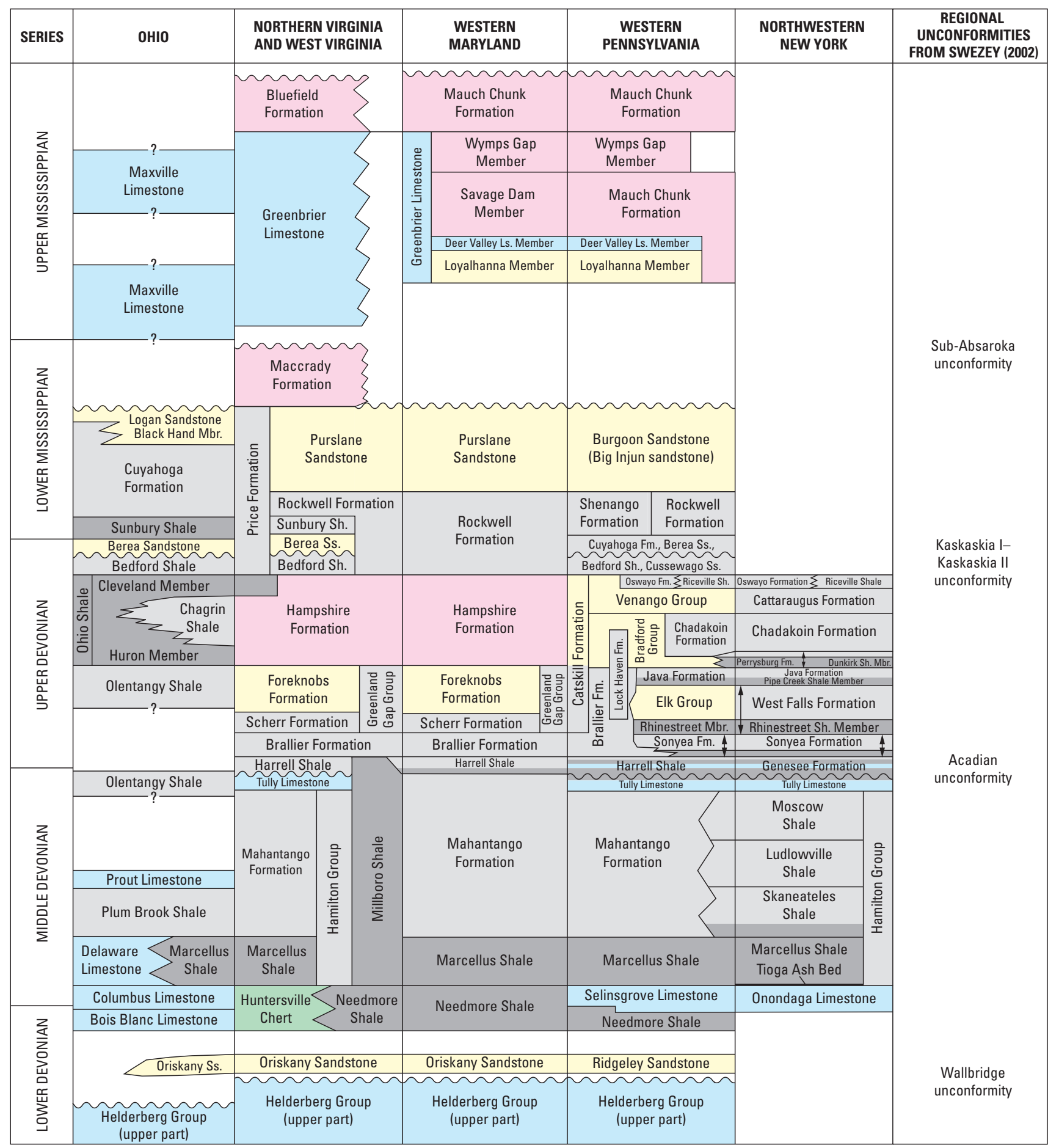

\section{EXPLANATION}

\section{Lithology}

Shale, siltstone, and (or) sandstone Black "gas" shale

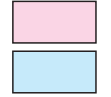

Red beds

Limestone

Sandstone

$\sim$ Unconformity
Figure 4. Chart showing generalized stratigraphic nomenclature for Lower Devonian through Upper Mississippian strata in the northern part of Appalachian Basin Petroleum Province (adapted from Patchen and others, 1985a,b; Bjerstedt and Kammer, 1988; Brezinski, 1989a,b, 1999; Filer and others, 1996; Matchen and Vargo, 1996; Milici, 1996c; Vargo and Matchen, 1996; Harper, 1999; Berg, 1999). Abbreviations are as follows: Fm., Formation; Gp., Group; Ls., Limestone; Mbr., Member; Sh., Shale; Ss., Sandstone; undiv., undivided. 


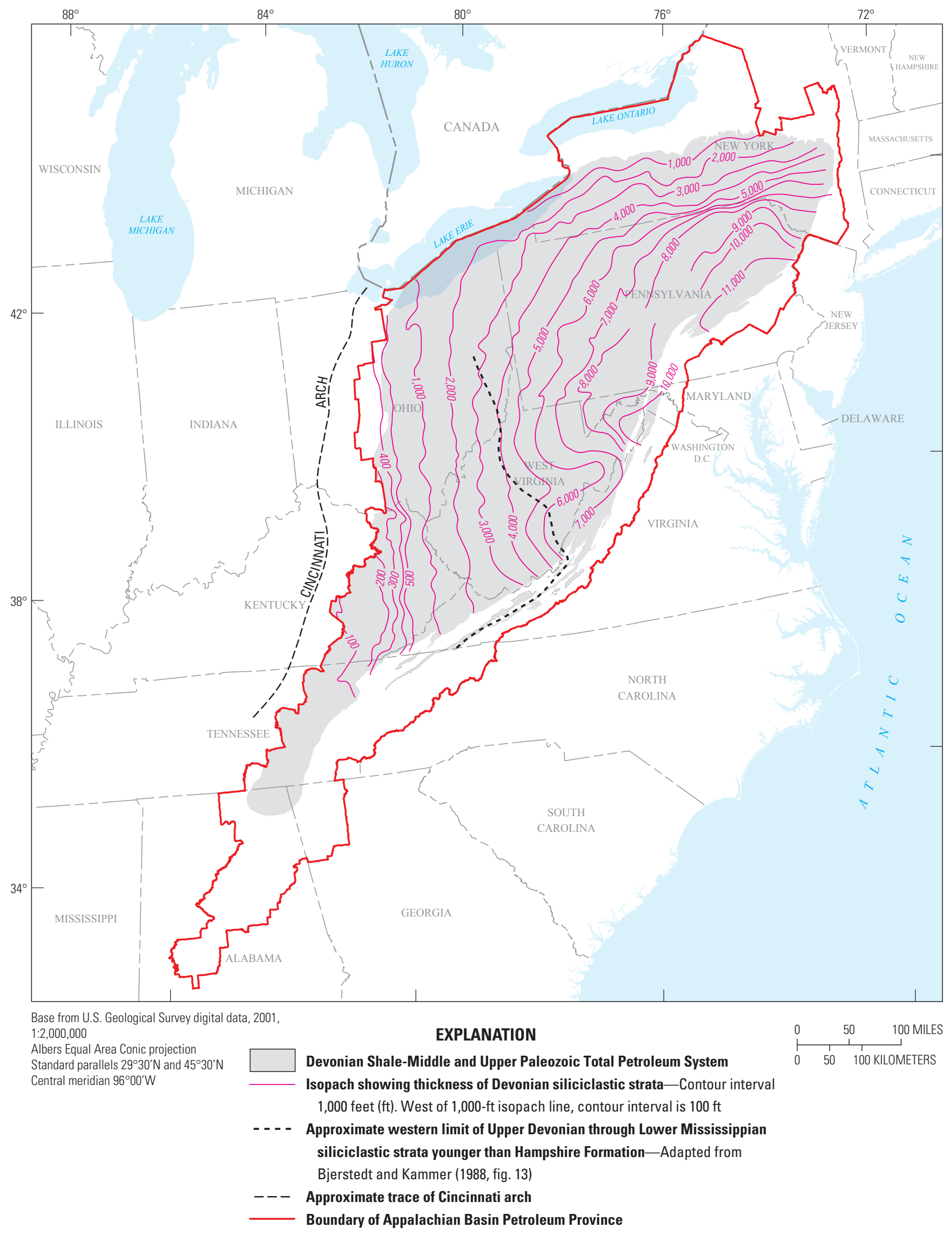

Figure 5. Map showing the extent of the Devonian Shale-Middle and Upper Paleozoic Total Petroleum System and thickness of Devonian siliciclastic strata in the Appalachian Basin Petroleum Province (adapted from de Witt and others, 1975). 


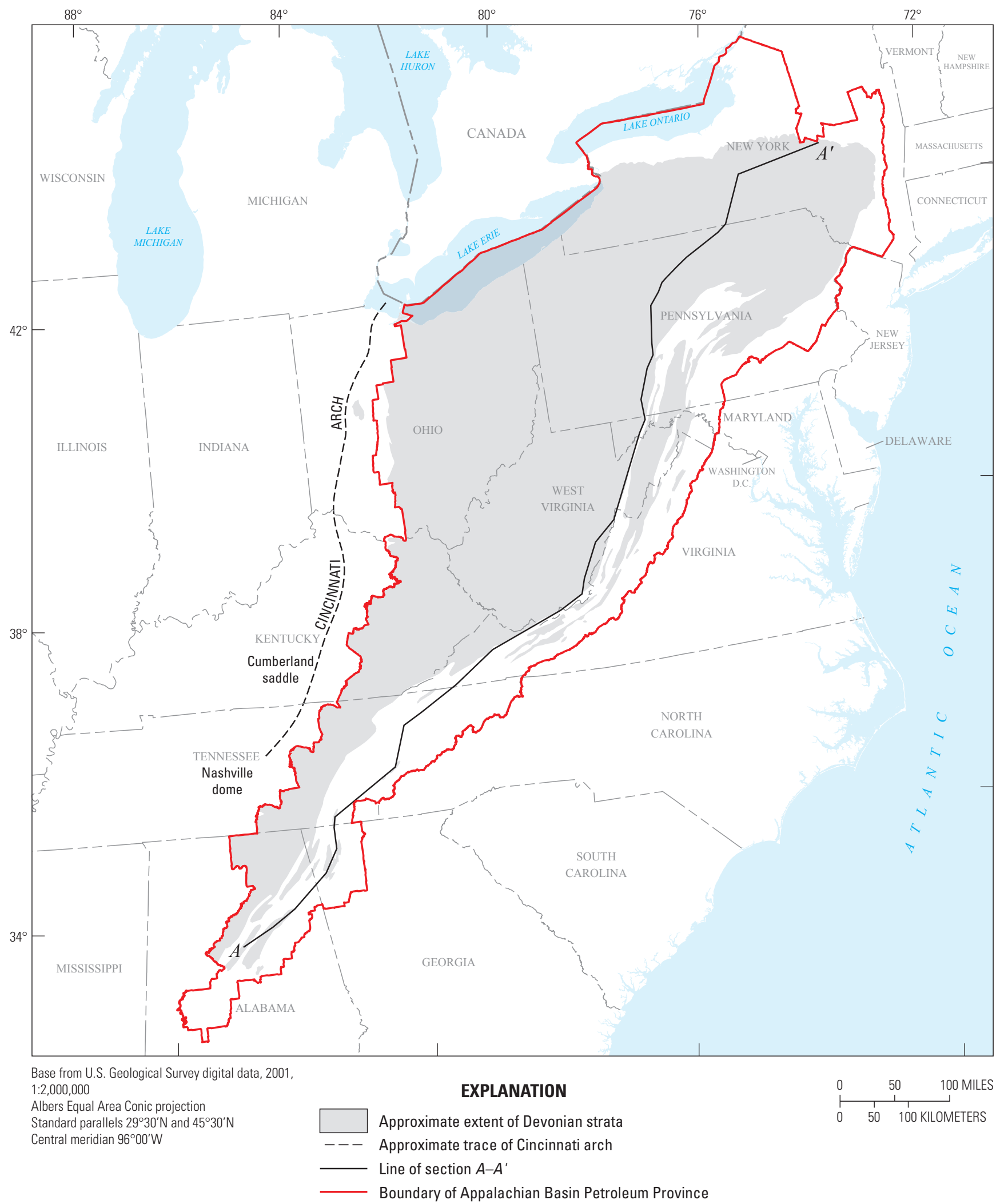

Figure 6. Map showing the extent of Devonian strata in the Appalachian Basin Petroleum Province (from Oliver and others, 1967) and the location of geologic cross section $A-A^{\prime}$ (fig. 7). 

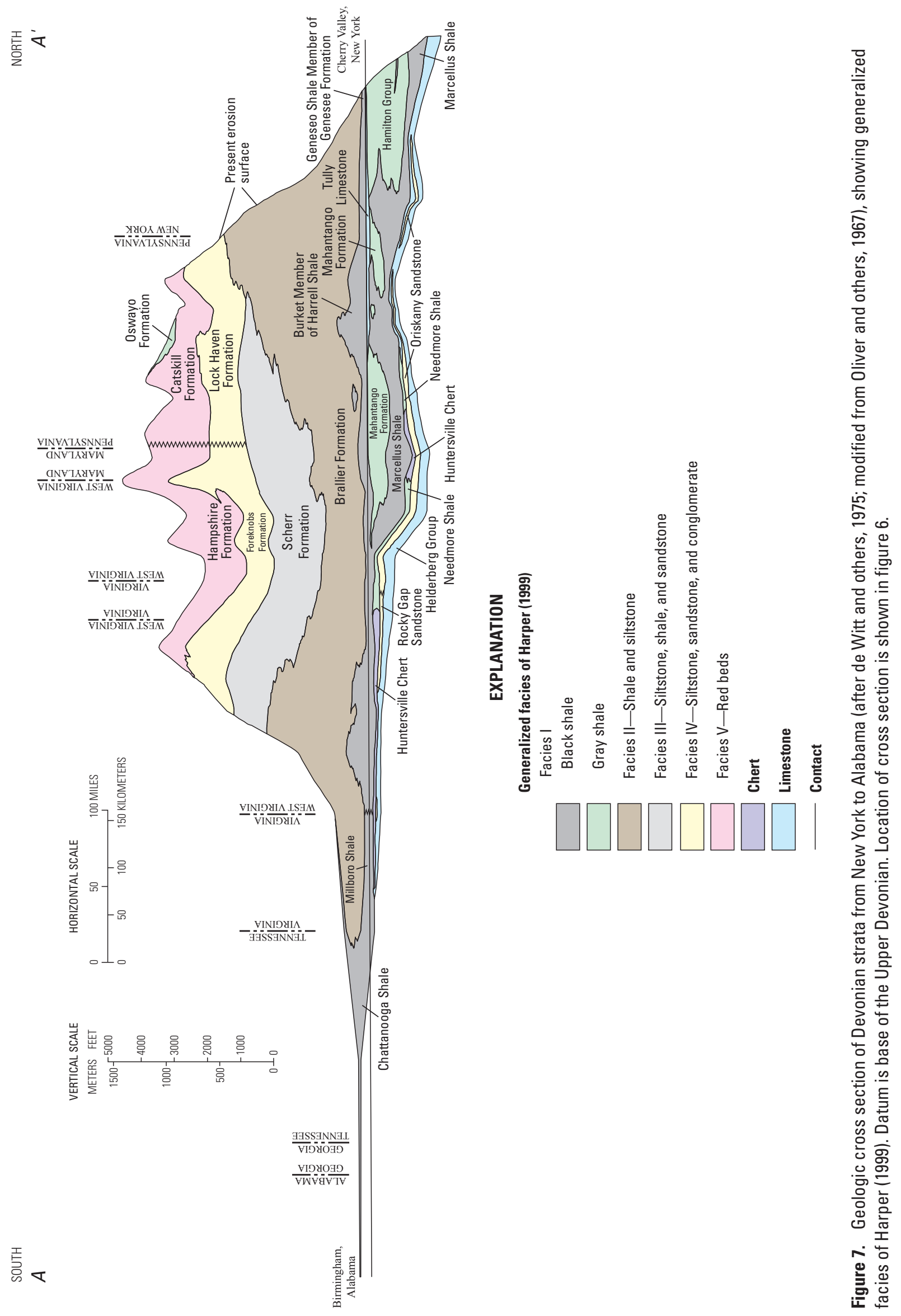
点


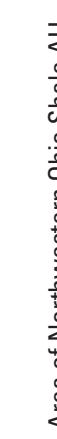

$\sqrt{5}$

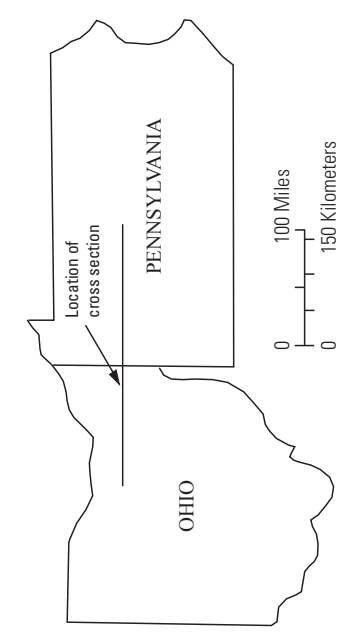

岂

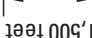

人|әнешіxo.dd $\forall$
.

营

$\stackrel{0}{0}$

西

文 흥

$\stackrel{0}{F}$

官

言.

존

हิ ㅇํㅁ

응흠

$\frac{\pi}{2}$

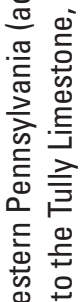

引 을

产 함

읗 홍

든

斗

की

풀

.을

.는

는

के

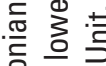



पे

등

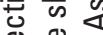

感离

舟定

응

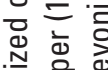

는 은 웜

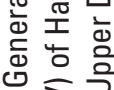

$0 \frac{1}{5}$

o 







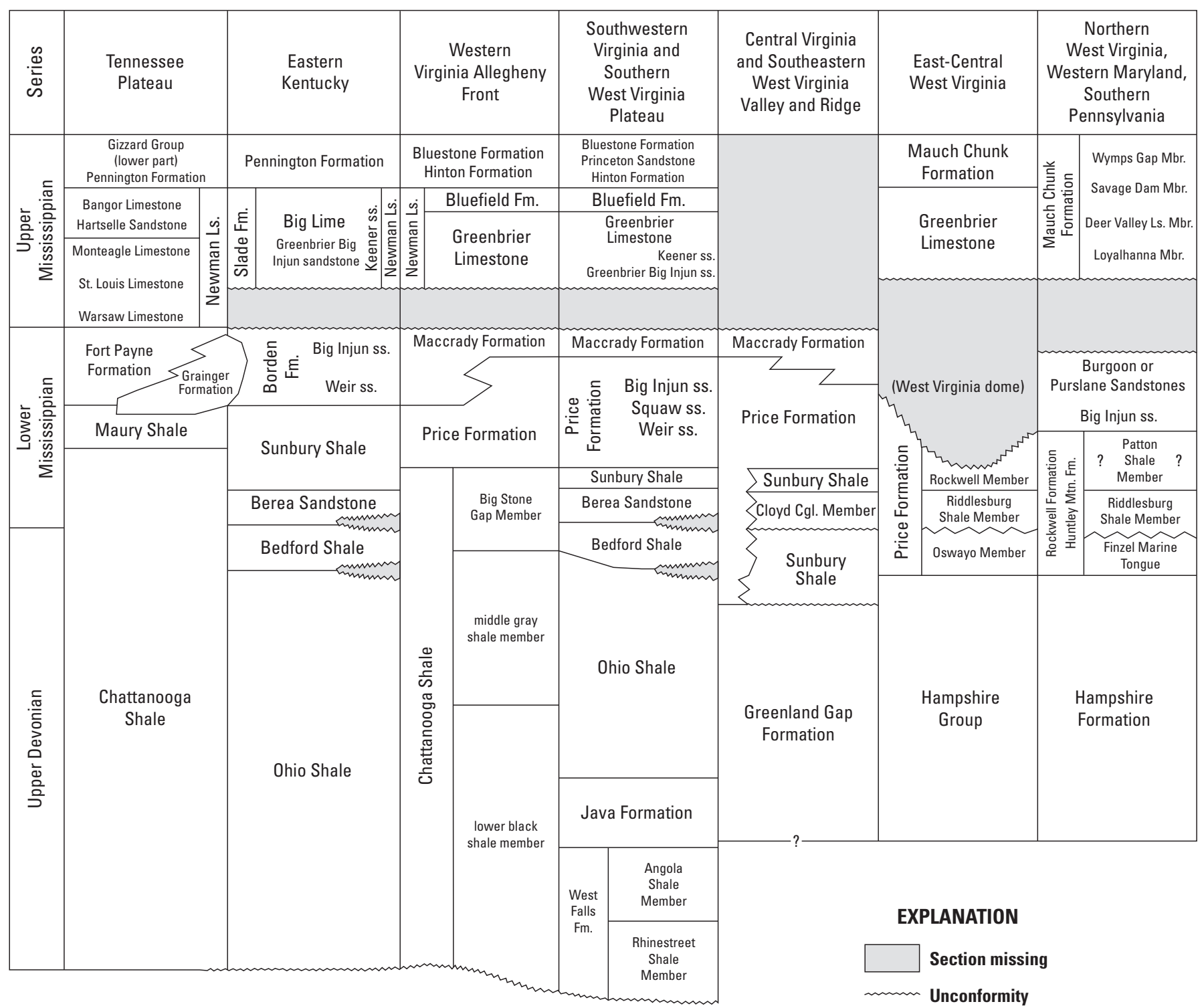

Figure 10. Chart showing stratigraphic nomenclature for the Upper Devonian through Upper Mississippian strata in the eastern part of the Appalachian Basin Petroleum Province (adapted from Patchen and others, 1985a,b; Bjerstedt and Kammer, 1988; Brezinski, 1989a,b, 1999; Filer and others, 1996; Matchen and Vargo, 1996; Milici, 1996c; Vargo and Matchen, 1996; Berg, 1999; Harper, 1999). Abbreviations are as follows: Cgl., Conglomerate; Fm., Formation; Ls., Limestone; Mbr., Member; Mtn., Mountain; ss., sandstone. 




Figure 11. Map of the Appalachian Basin Petroleum Province, illustrating the extent of the Devonian and Lower Mississippian shale, the extent of oil in Devonian shale, and vitrinite-reflectance contours (Weary and others, 2000, 2001; Repetski and others, 2002, 2005; John R. Repetski, oral commun., 2008). 


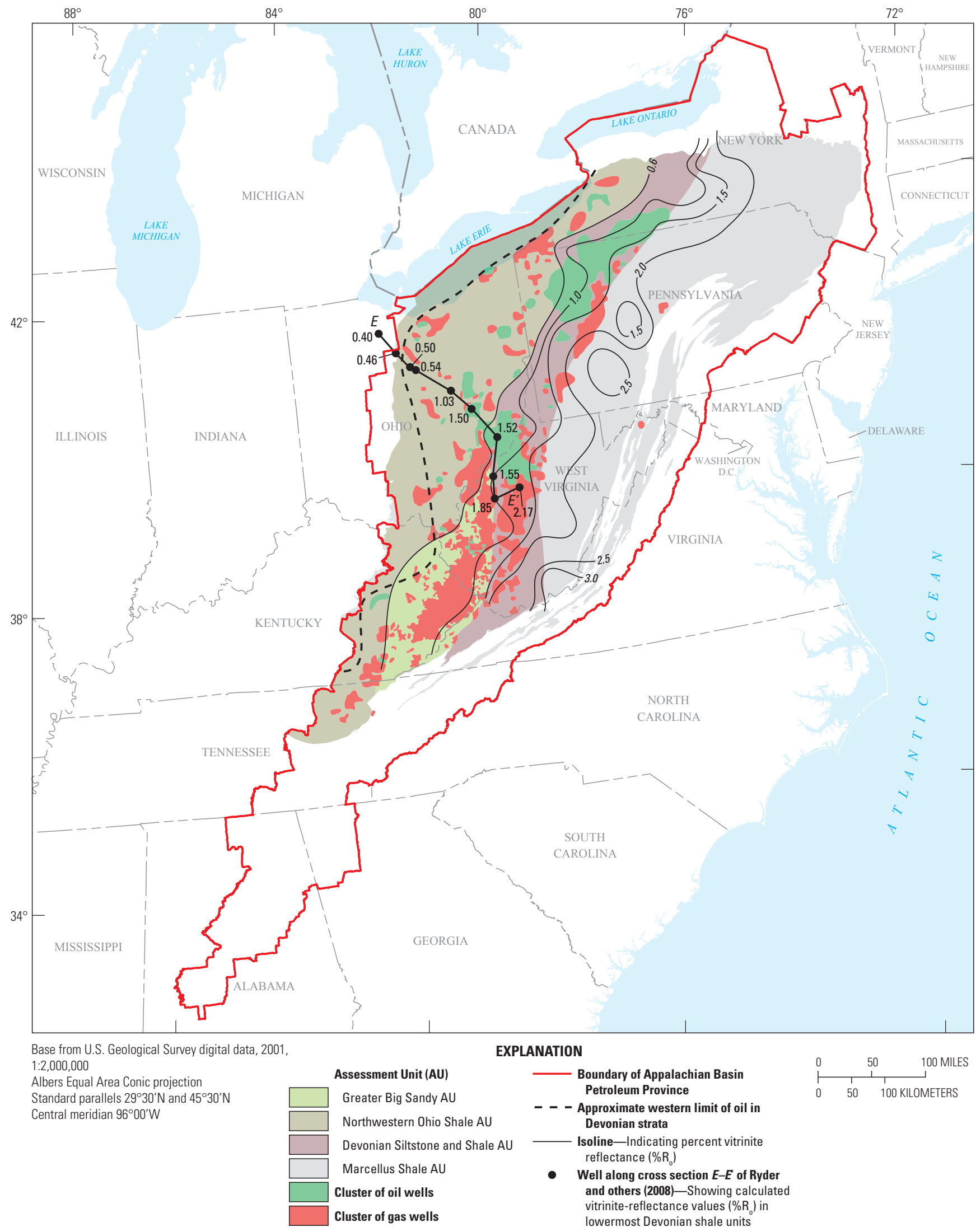

Figure 12. Map showing the four Devonian gas shale assessment units and the distribution of oil and gas wells within the assessment units. Map also shows the vitrinite-reflectance values calculated for wells along cross section $E-E^{\prime}$ (Rowan and others, 2004a,b) as well as vitrinite-reflectance isolines derived from dispersed vitrinite data (Weary and others, 2000, 2001; Repetski and others, 2002, 2005). 


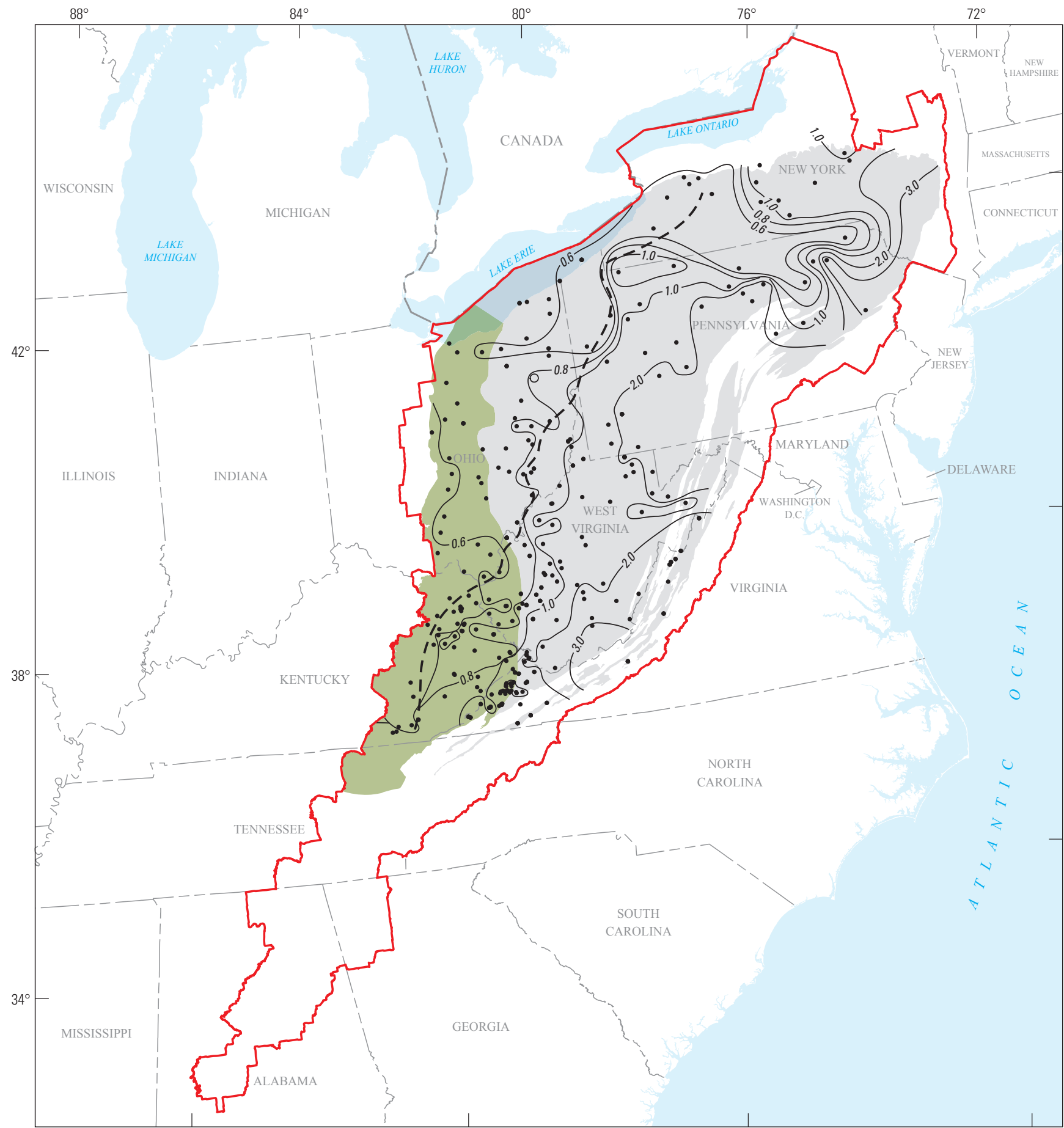

Base from U.S. Geological Survey digital data, 2001, $1: 2,000,000$

Albers Equal Area Conic projection

Standard parallels $29^{\circ} 30^{\prime} \mathrm{N}$ and $45^{\circ} 30^{\prime} \mathrm{N}$

Central meridian $96^{\circ} 00^{\prime} \mathrm{W}$
EXPLANATION

Extent of Devonian shale beyond the area of the Marcellus Shale

Extent of Devonian Marcellus Shale (Devonian)—Includes areas beyond the extent of the Marcellus Shale Assessment Unit

Boundary of Appalachian Basin Petroleum Province Isoline-Indicating percent vitrinite reflectance $\left(\% \mathrm{R}_{0}\right)$

- - - $\quad 0.6-\% R_{0}$ isoline used in 2002 assessment by U.S. Geological Survey $0.6-\% \mathrm{R}$ isoline based on data from Repetski and others (2008) and

R.C. Milici (U.S. Geological Survey, unpub. data, 2002-2012)

- Location of vitrinite-reflectance sample

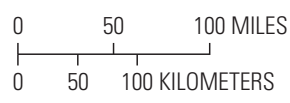


Figure 13 (facing page). Map showing the extent of the Devonian Marcellus Shale and Millboro Shale, and the extent of Devonian shale beyond the area of the Marcellus and Millboro Shales. Map also shows the $0.6-\% \mathrm{R}_{0}$ vitrinite-reflectance isoline used in the 2002 USGS assessment, and vitrinitereflectance isolines based on data from Repetski and others (2008) and R.C. Milici (USGS, unpub. data, 2002-2012). 


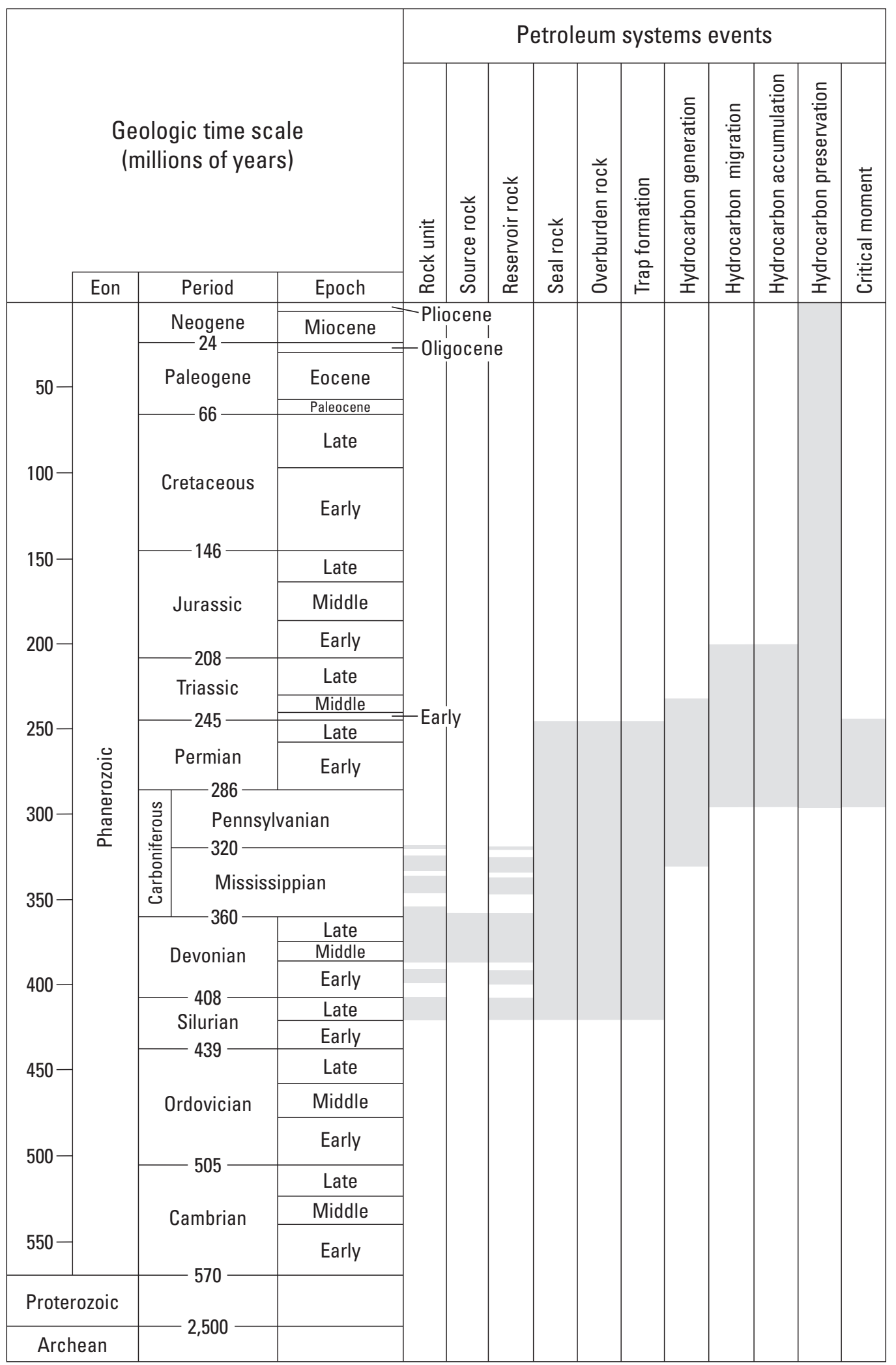


Figure 14 (facing page). Chart showing petroleum system events for the Devonian Shale-Middle and Upper Paleozoic Total Petroleum System in the Appalachian Basin Petroleum Province. Time scale is from Harland and others (1990). 


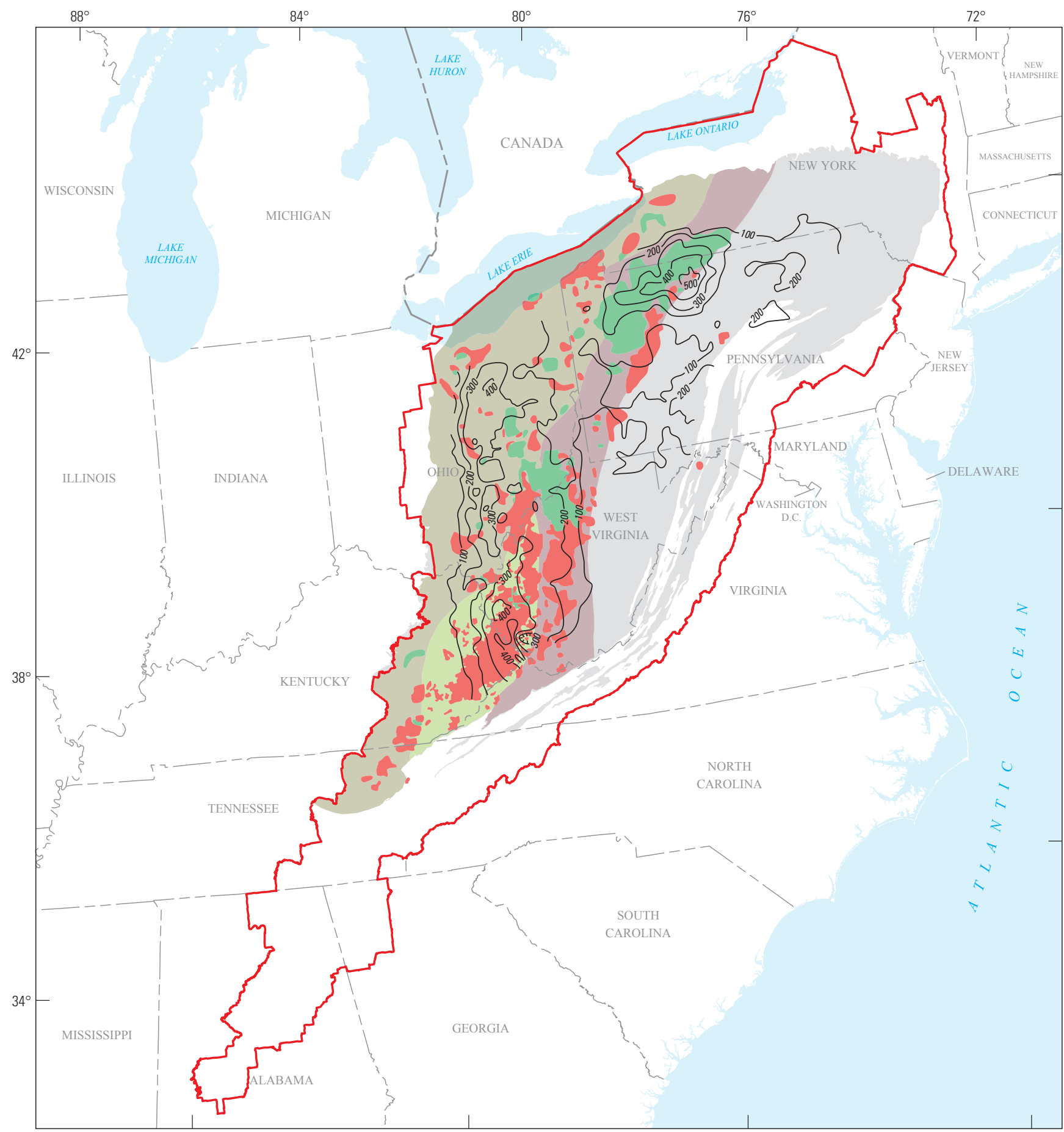

Base from U.S. Geological Survey digital data, 2001, $1: 2,000,000$

Albers Equal Area Conic projection

Standard parallels $29^{\circ} 30^{\prime} \mathrm{N}$ and $45^{\circ} 30^{\prime} \mathrm{N}$

Central meridian $96^{\circ} 00^{\prime} \mathrm{W}$

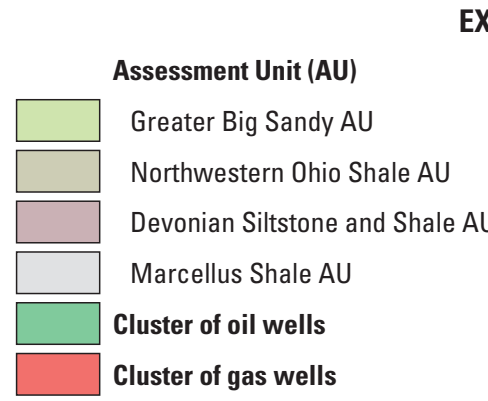

EPLANATION

Boundary of Appalachian Basin

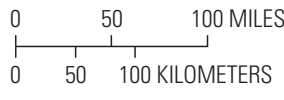
Petroleum Province

sopach-Showing net thickness of radioactive shale, in feet. Hachures indicate direction of thinning 
Figure 15 (facing page). Map of Devonian shale assessment units, showing net thickness of black shale and areas of closely spaced oil and gas wells. Net thickness (isopach) lines are from de Witt and others (1993, fig. 2). 


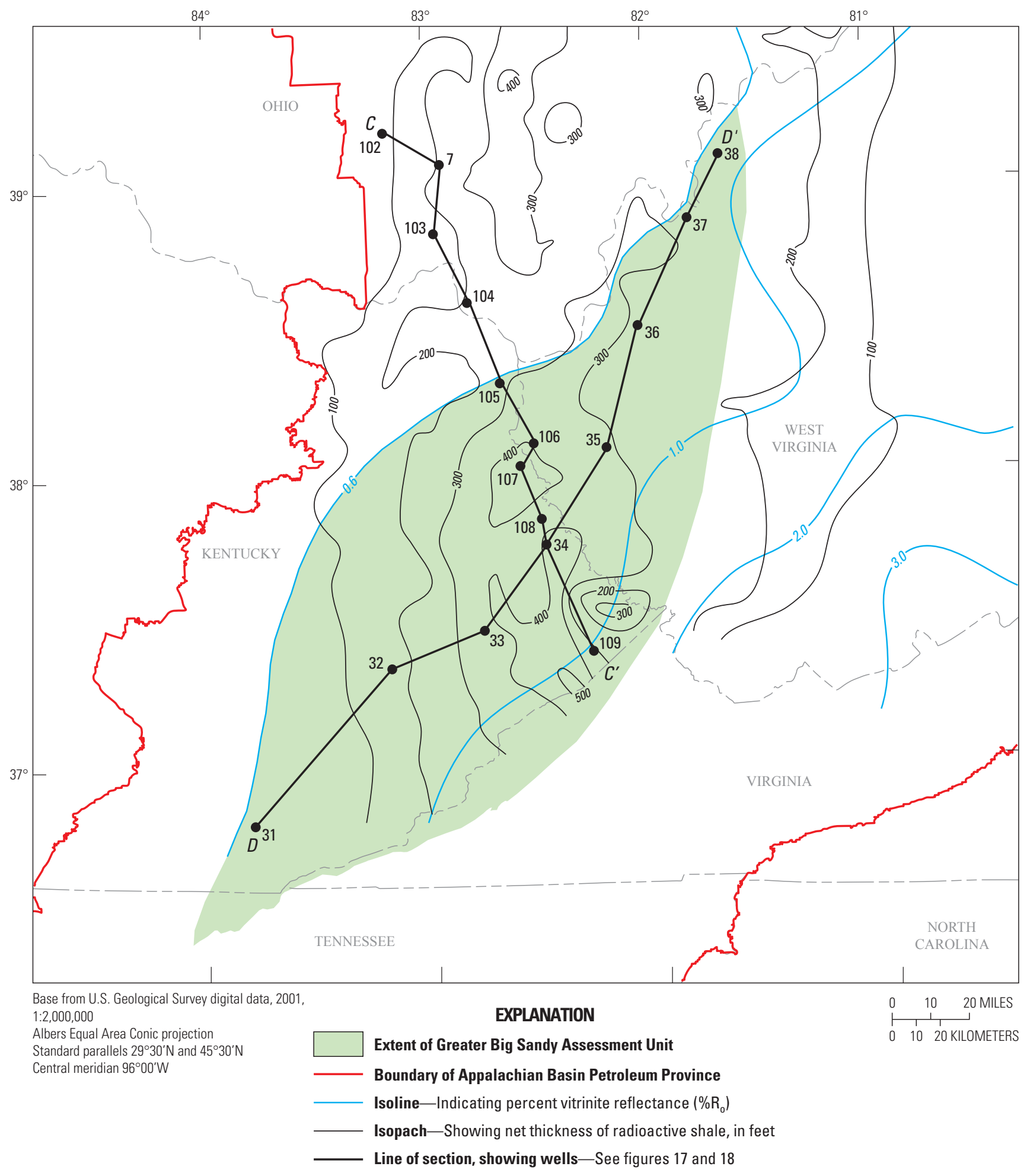


Figure 16 (facing page). Map showing the extent of the Greater Big Sandy Assessment Unit, thermal maturity isolines, and net thickness of black shale. Well numbers and lines of cross sections are from de Witt and others (1993). Cross sections $C-C^{\prime}$ and $D-D^{\prime}$ are shown on figures 17 and 18 , respectively. See figure 15 for source of vitrinite-reflectance data. 
$D$

VERTICAL SCALE

METERS FEET


Figure 17. Stratigraphic cross section $D-D^{\prime}$, showing Devonian and Lower Mississippian strata across the Greater Big Sandy Assessment Unit in eastern Kentucky and western West Virginia. Location of cross section is shown in figure 16 (after de Witt and others, 1993, pl. 3, section $B-B$ 1. 


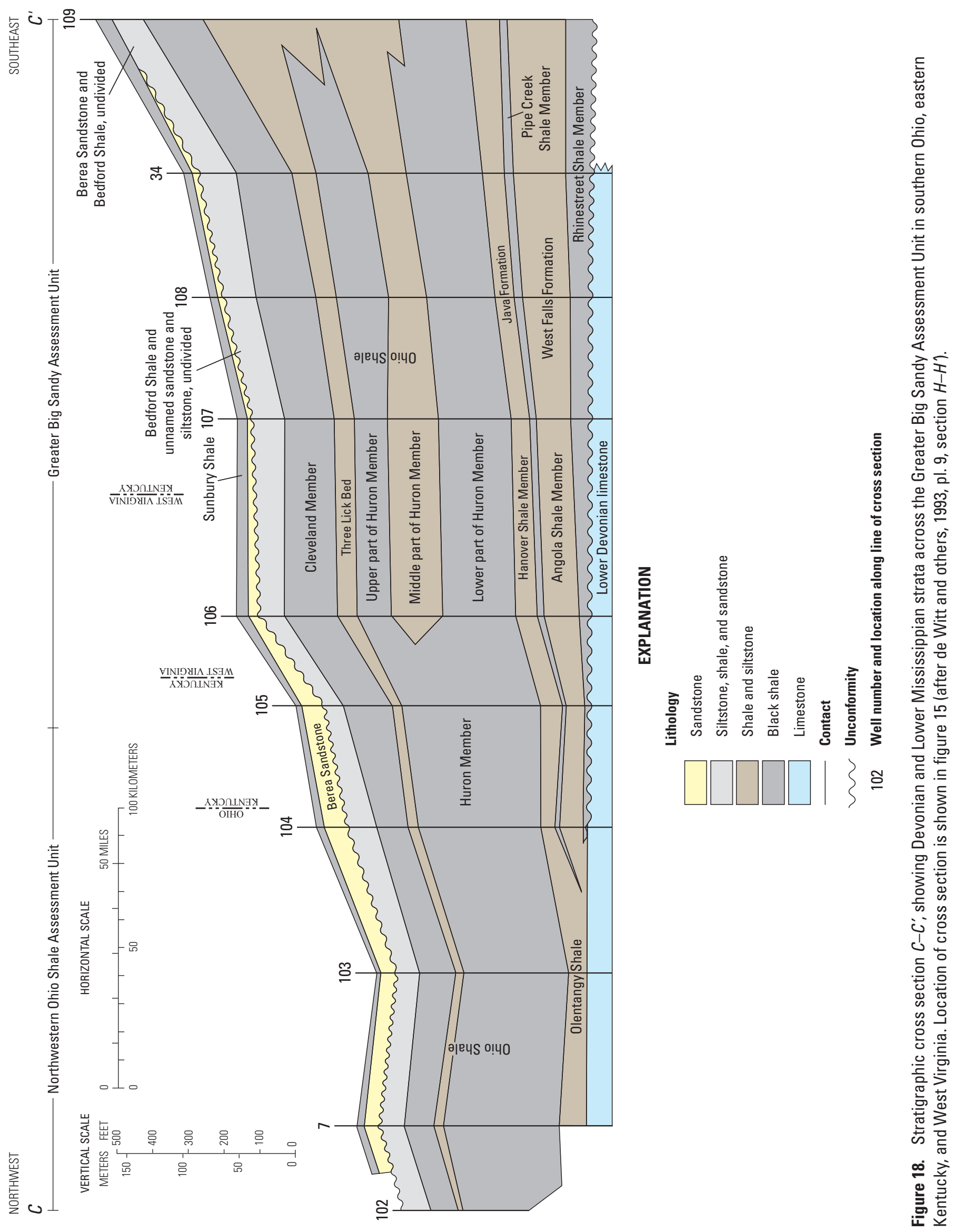




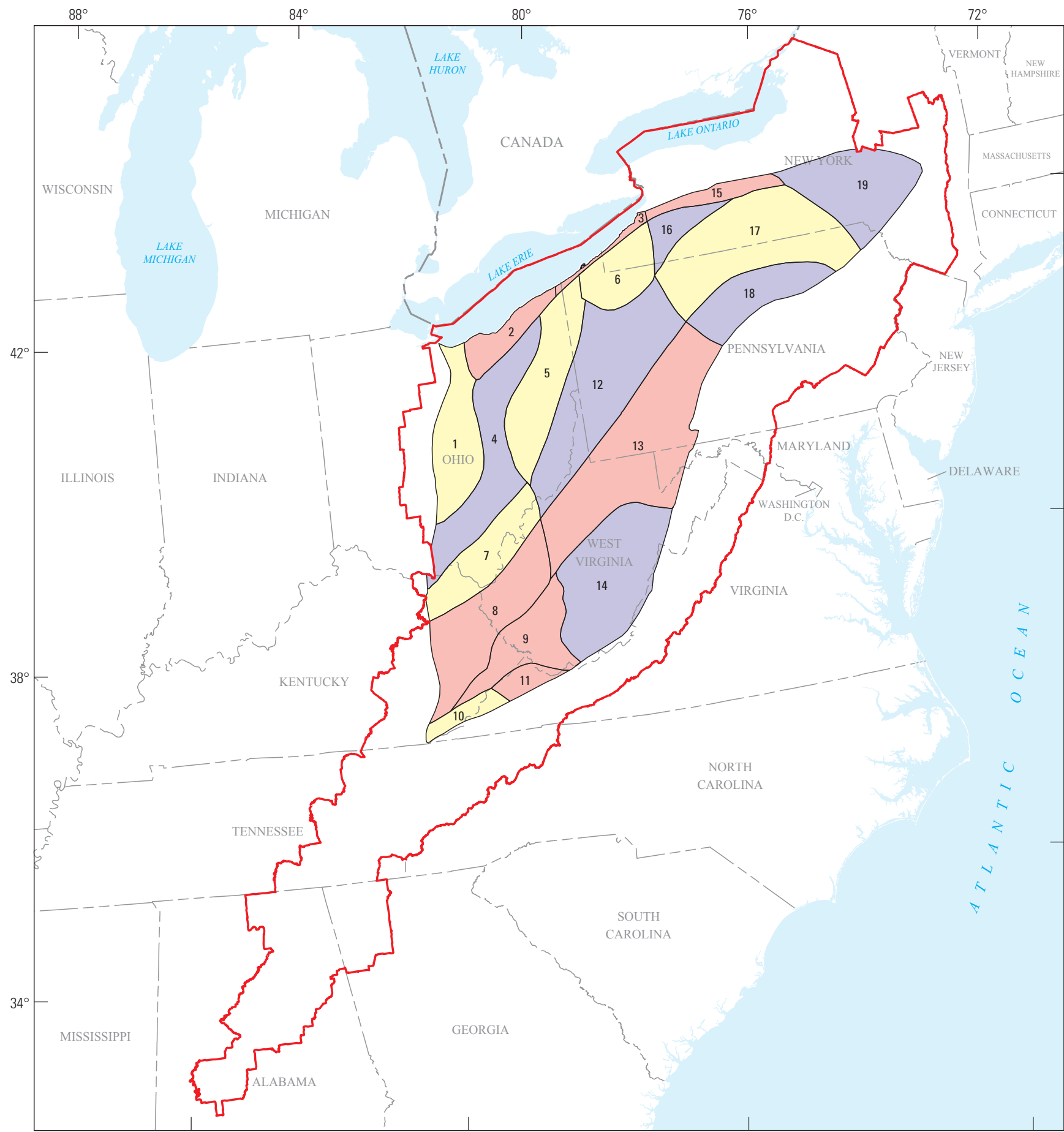

Base from U.S. Geological Survey digital data, 2001, $1: 2,000,000$

Albers Equal Area Conic projection

Standard parallels $29^{\circ} 30^{\prime} \mathrm{N}$ and $45^{\circ} 30^{\prime} \mathrm{N}$

Central meridian $96^{\circ} 00^{\prime} \mathrm{W}$

\section{EXPLANATION}

Shale gas recoverability estimates Gas plays of Charpentier and others (1993)

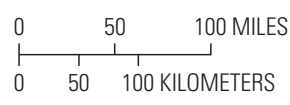
of Charpentier and others (1993)

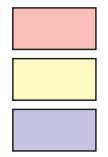

Good

Moderate

Poor

\section{Boundary of Appalachian Basin} Petroleum Province

\section{North-Central Ohio}

2 Western Lake Erie

3 Eastern Lake Erie

4 Plateau Ohio

5 Eastern Ohio

6 Western Penn-York

7 Southern Ohio Valley

8 Western Rome Trough

9 Tug Fork

10 Pine Mountain
11 Plateau Virginia

12 Pittsburgh Basin

13 Eastern Rome Trough

14 New River

15 Portage Escarpment

16 Cattaraugus Valley

17 Penn-York Plateau

18 Western Susquehanna

19 Catskill 
Figure 19 (facing page). Map showing the qualitative assessment of gas recoverability from Devonian shale within each gas play of the Appalachian Basin Petroleum Province (from Charpentier and others, 1993). Estimates of gas-in-place resources in these plays are given in table 2. 


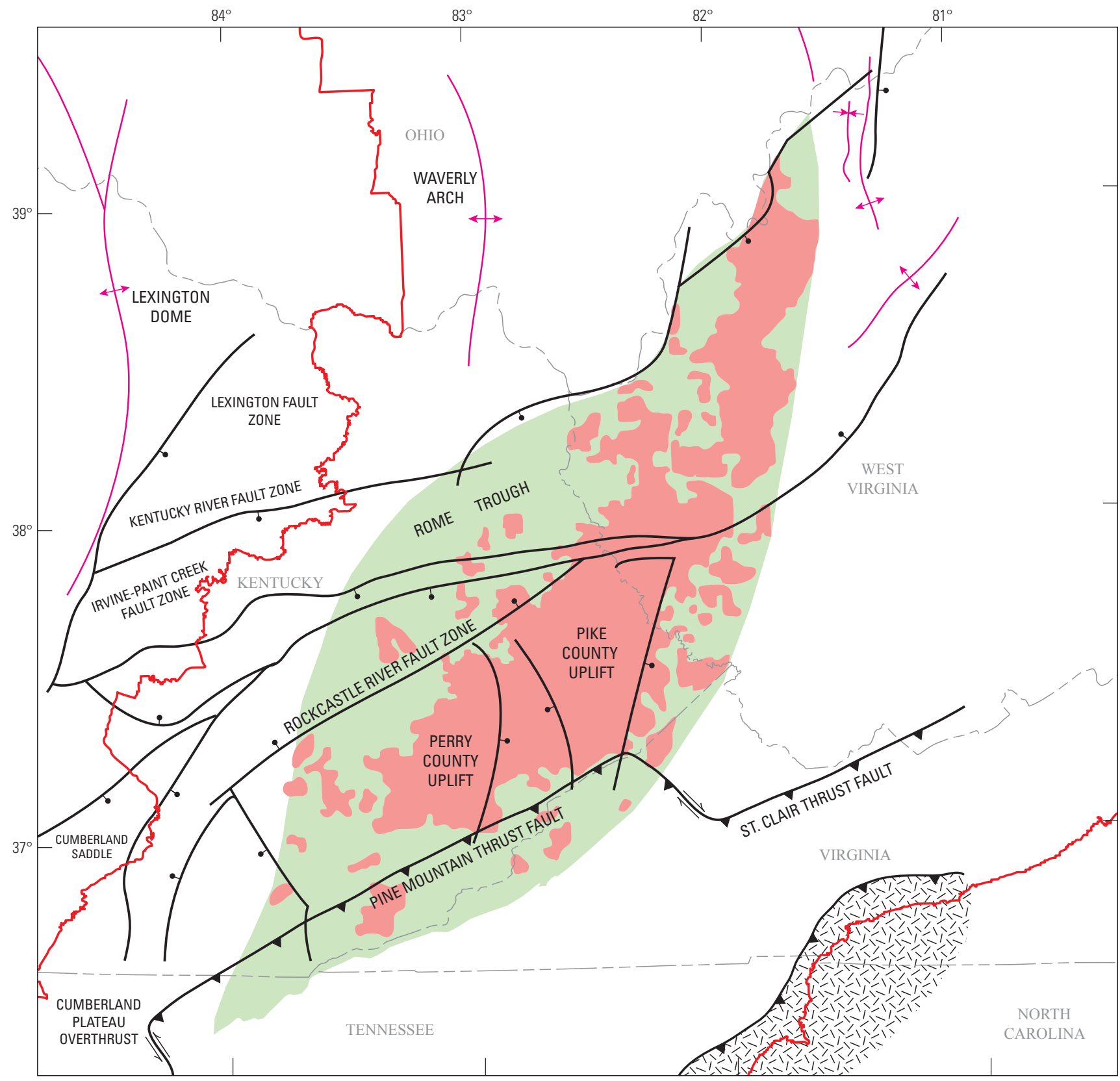

Base from U.S. Geological Survey digital data, 2001, $1: 2,000,000$

Albers Equal Area Conic projection

Standard parallels $29^{\circ} 30^{\prime} \mathrm{N}$ and $45^{\circ} 30^{\prime} \mathrm{N}$

Central meridian $96^{\circ} 00^{\prime} \mathrm{W}$

\section{EXPLANATION}

Cluster of gas wells

\section{Extent of Greater Big Sandy Assessment Unit}

\section{Crystalline rocks}

Boundary of Appalachian Basin Petroleum Province Faults

- Normal fault—Bar and ball on downthrown block

$\rightleftharpoons$ Strike-slip fault-Arrows show sense of relative movement

_ـ Thrust fault-Teeth on upper plate

\section{Folds}

$\frac{\uparrow}{v}$ Anticline

$\checkmark$ Syncline 


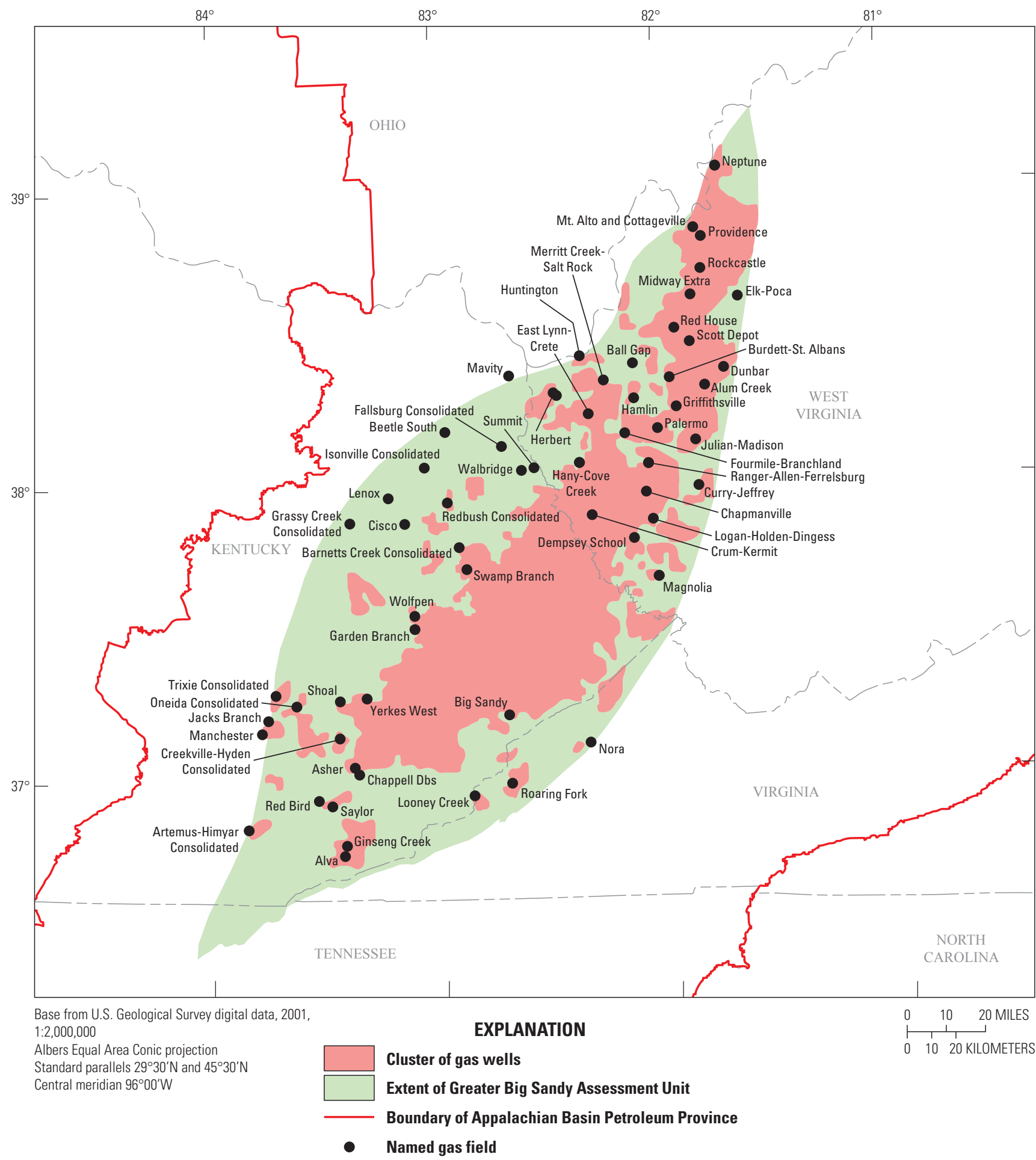

Figure 21. Map showing the locations of gas wells and named gas fields producing from Devonian shale in the Greater Big Sandy Assessment Unit (data from Roen and Walker, 1996). The gas field locations are approximate field centers.

Figure 20 (facing page). Map showing the relation of the Greater Big Sandy Assessment Unit to regional geologic structure. Structural geology is adapted from Ryder and others (2008). 


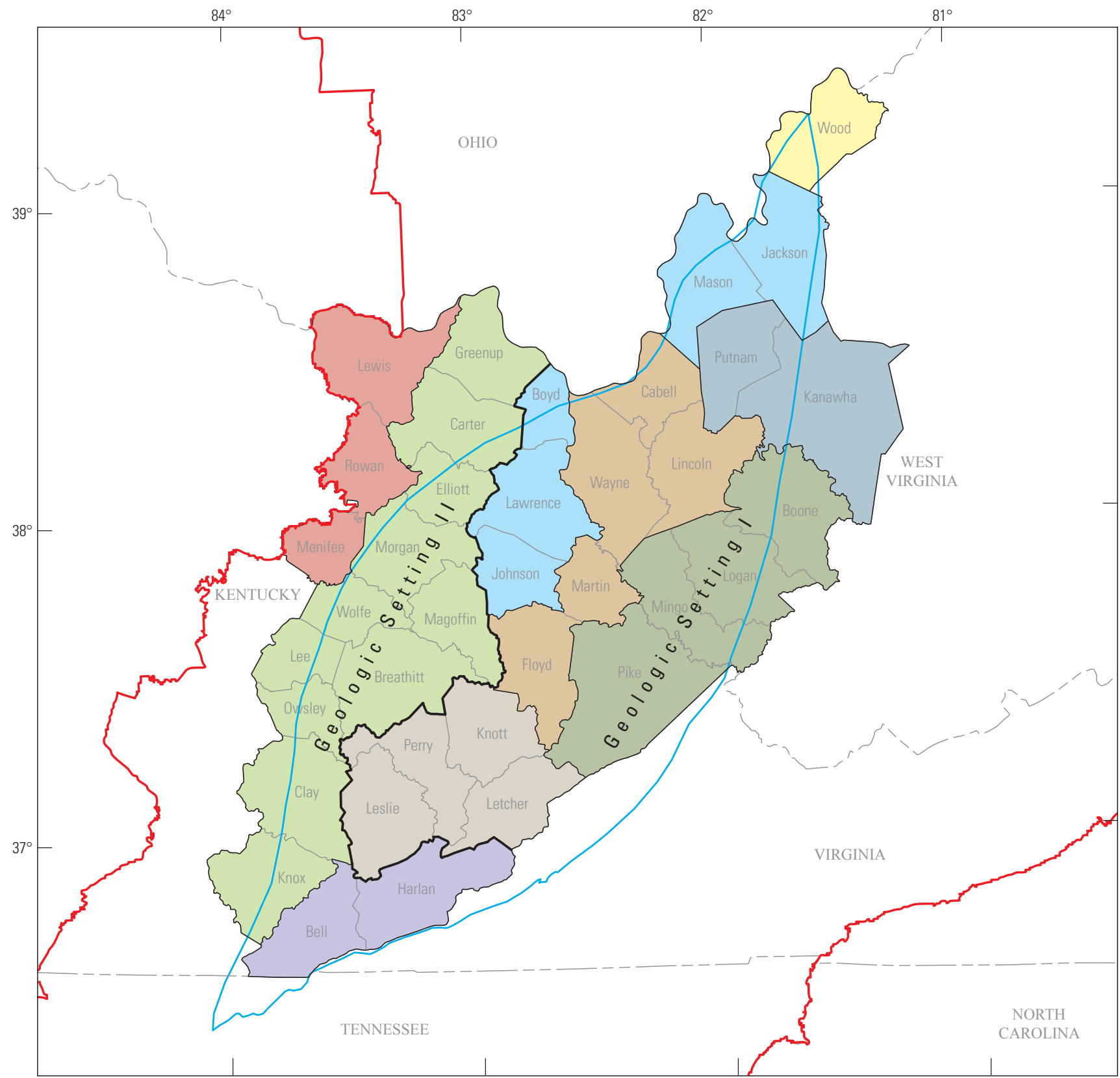

Base from U.S. Geological Survey digital data, 2001, $1: 2,000,000$

Albers Equal Area Conic projection

Standard parallels $29^{\circ} 30^{\prime} \mathrm{N}$ and $45^{\circ} 30^{\prime} \mathrm{N}$

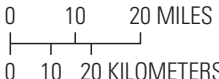

Central meridian $96^{\circ} 00^{\prime} \mathrm{W}$

\section{EXPLANATION}

Geological Setting I (areas of known production) in Kentucky and West Virginia (from Kuuskraa and others, 1985)

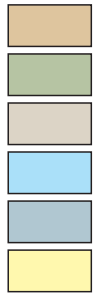

Area I

Area II

Area III

Area IV

Area V

Area VI
Geological Setting II (areas of limited production) in Kentucky (from Kuuskraa and others, 1985)

Shallow target

Medium target

Deep target

Boundary of Appalachian Basin Petroleum Province

Boundary of Greater Big Sandy Assessment Unit 




Figure 23. Graph showing the distribution of estimated ultimate recovery (EUR) values per well for wells in Devonian shale of eastern Kentucky (Troy Cook, U.S. Geological Survey, unpub. data, 2002; using data from Roen and Walker, 1996). The EUR data were sorted according to date and then partitioned chronologically into three groups, each of which had the same number of data. Separate graphs are shown for the early third, middle third, and late third of EUR values.

Figure 22 (facing page). Map showing the geological settings and partitioned areas of Kuuskraa and others (1985) in the Greater Big Sandy Assessment Unit. Geologic setting III (areas of speculative production) is not shown. See table 2 for estimates of gas-in-place (GIP) resources in plays described by Charpentier and others (1993), and see table 3 for gas geochemistry data from Streib (1981). 


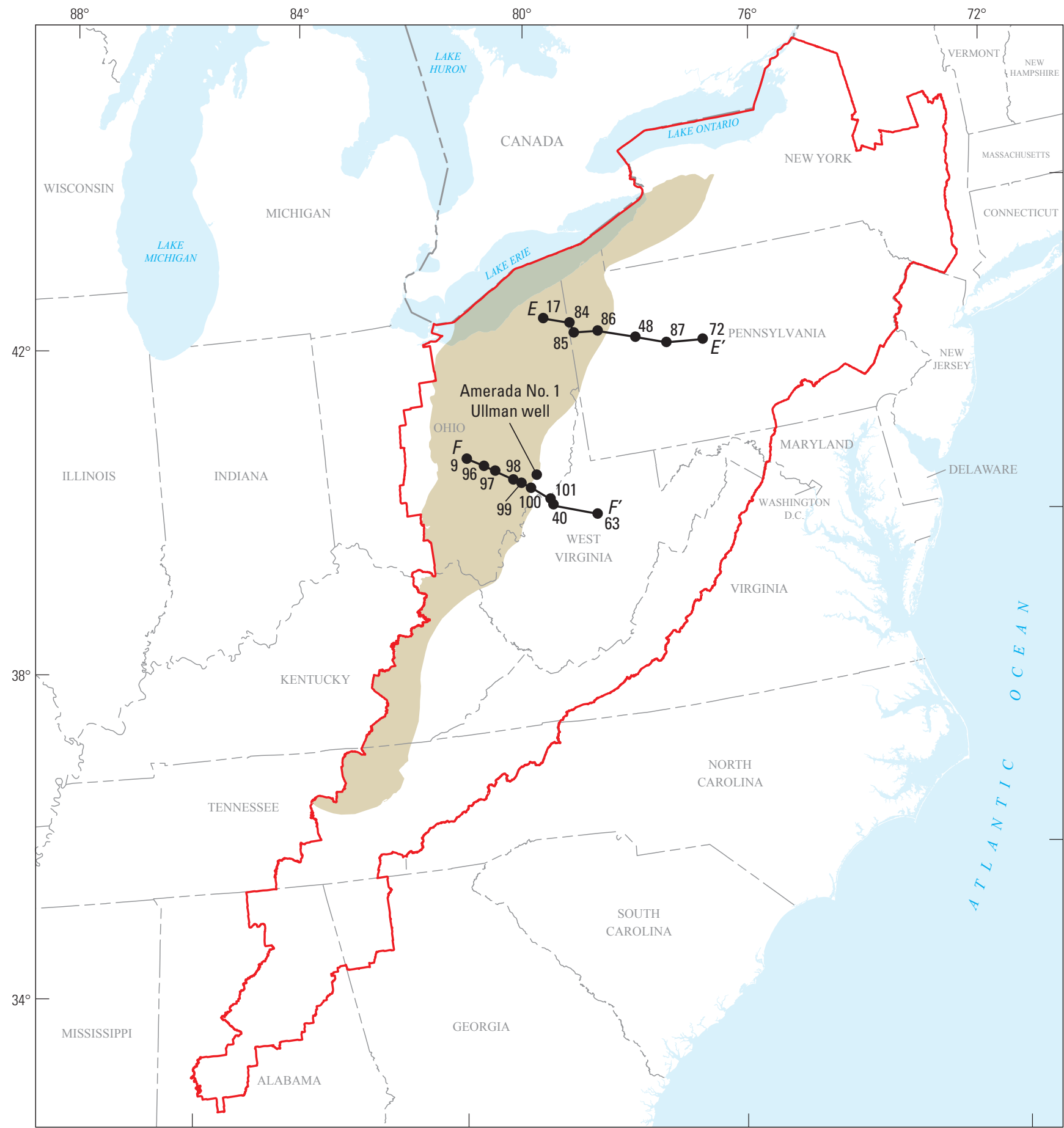

Base from U.S. Geological Survey digital data, 2001, 1:2,000,000

Albers Equal Area Conic projection

Standard parallels $29^{\circ} 30^{\prime} \mathrm{N}$ and $45^{\circ} 30^{\prime} \mathrm{N}$

EXPLANATION

Central meridian $96^{\circ} 00^{\prime} \mathrm{W}$

Extent of Northwestern Ohio Shale Assessment Unit

Boundary of Appalachian Basin Petroleum Province

Line of section, showing wells-See figures 25 and 26

- Well (not located along line of section)

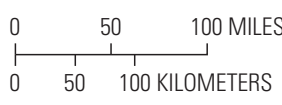


Figure 24 (facing page). Map showing the outline of the Northwestern Ohio Shale Assessment Unit, the location of the Amerada No.1 Ullman well, and the locations of cross sections $E-E^{\prime}$ (fig. 25) and $F-F^{\prime}$ (fig. 26). Well locations are from de Witt and others (1993) and Ryder and others (1998). 


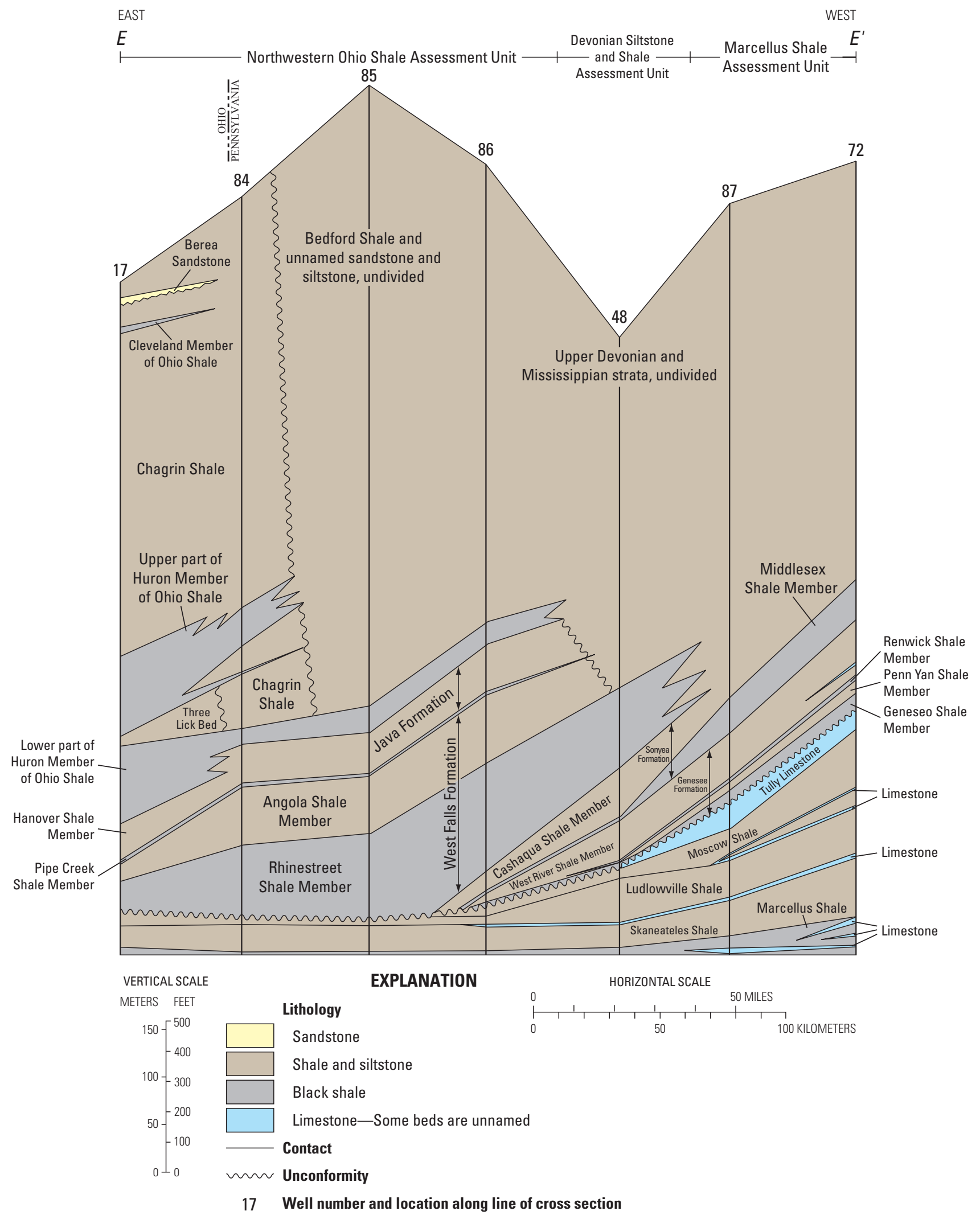

Figure 25. Cross section $E-E^{\prime}$, showing the Devonian and Lower Mississippian strata across western Pennsylvania and northeastern Ohio (after de Witt and others, 1993, pl. 6, section $E-E^{\prime}$ ). Numbers along top of section refer to the well numbers of de Witt and others (1993). Cross section location is shown in figure 24. 
$F$

Northwestern Ohio Shale Assessment Unit

Devonian Siltstone and Shale $F^{\prime}$ Assessment Unit

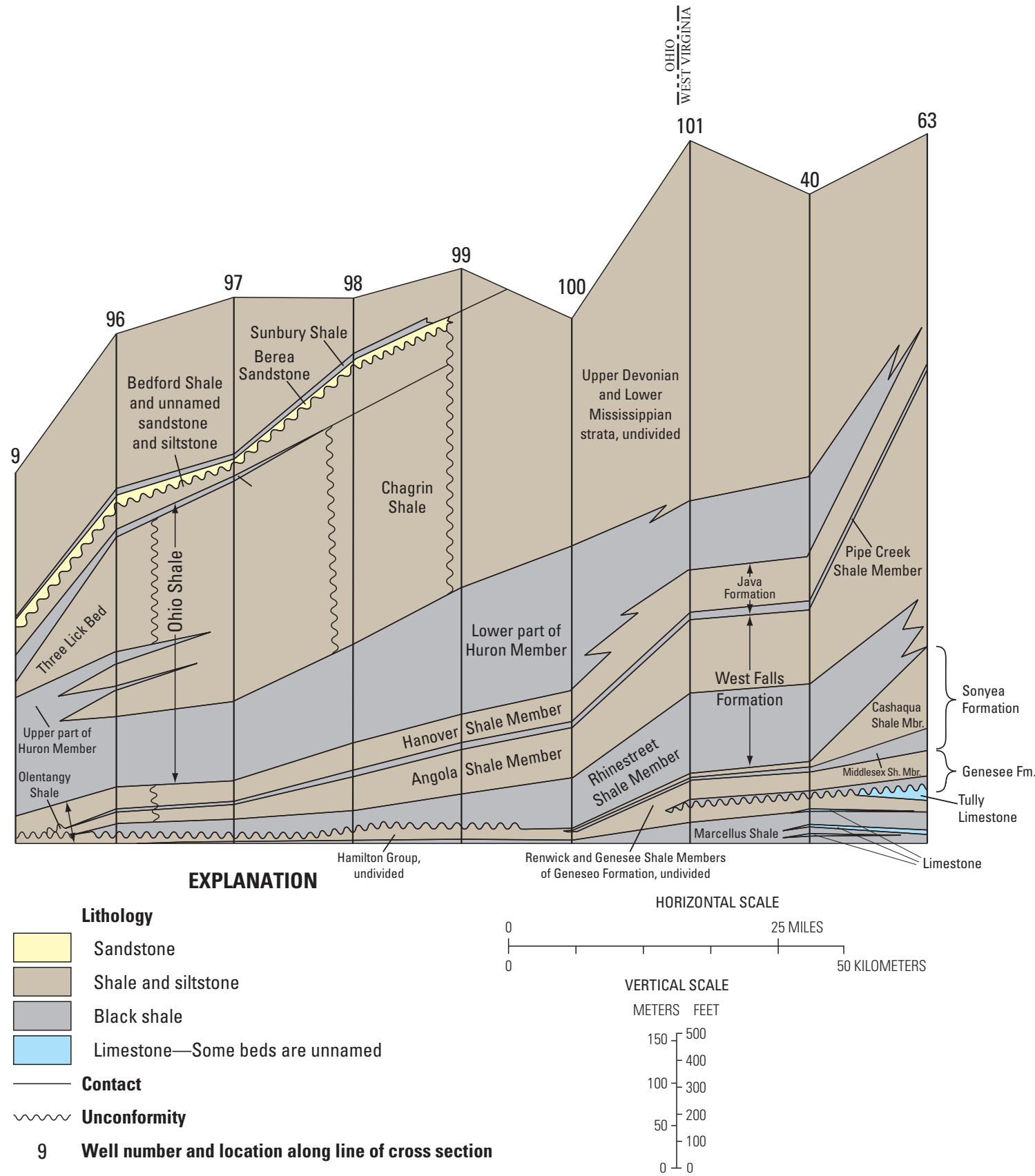

Figure 26. Cross section $F-F^{\prime}$, showing the Devonian and Lower Mississippian strata across western West Virginia and east-central Ohio (after de Witt and others, 1993, pl. 8, section $G-G^{\prime}$ ). Numbers along top of section refer to the well numbers of de Witt and others (1993). Cross section location is shown in figure 24. 


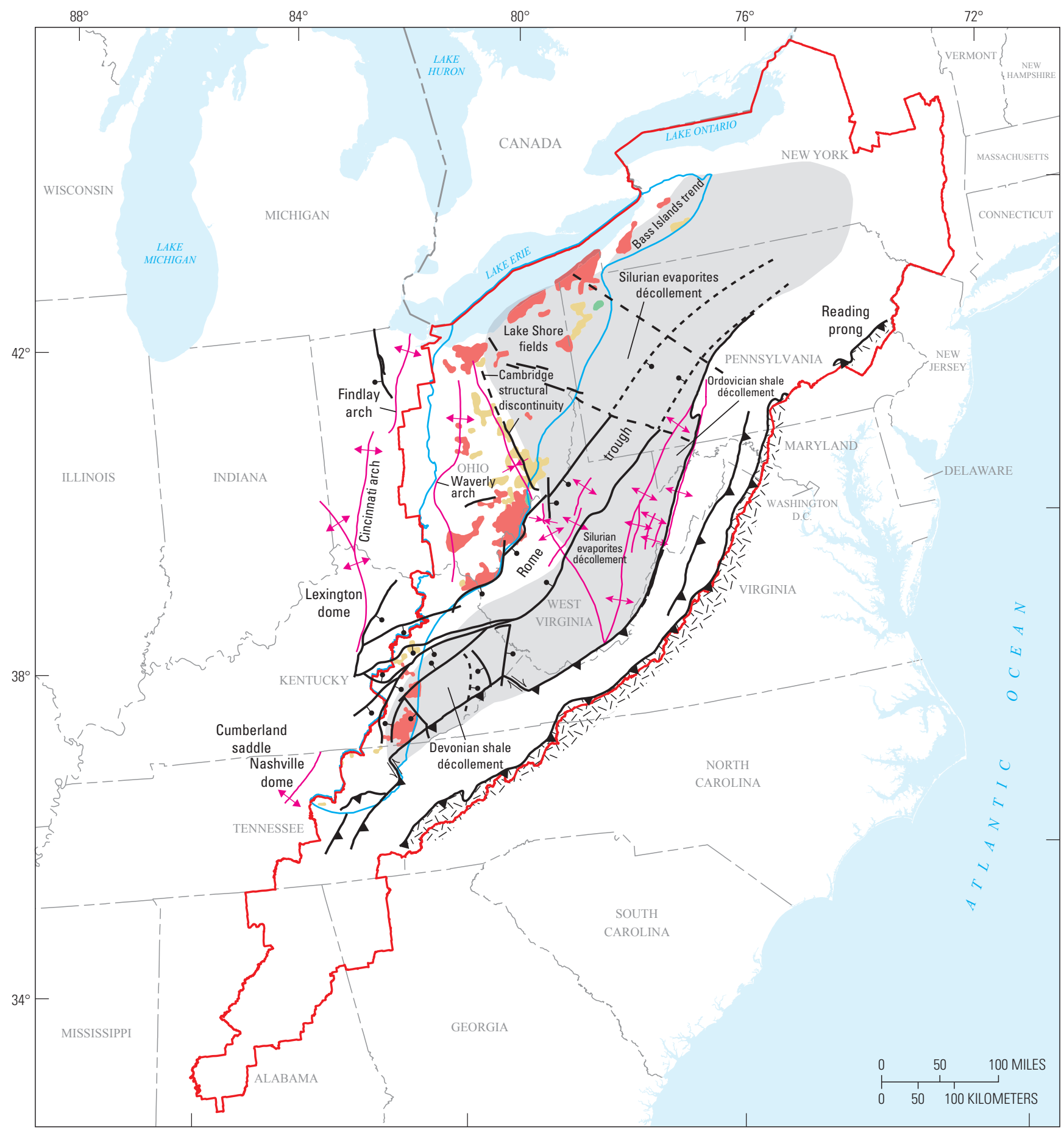

Base from U.S. Geological Survey digital data, 2001, $1: 2,000,000$

Albers Equal Area Conic projection

Standard parallels $29^{\circ} 30^{\prime} \mathrm{N}$ and $45^{\circ} 30^{\prime} \mathrm{N}$

Central meridian $96^{\circ} 00^{\prime} \mathrm{W}$

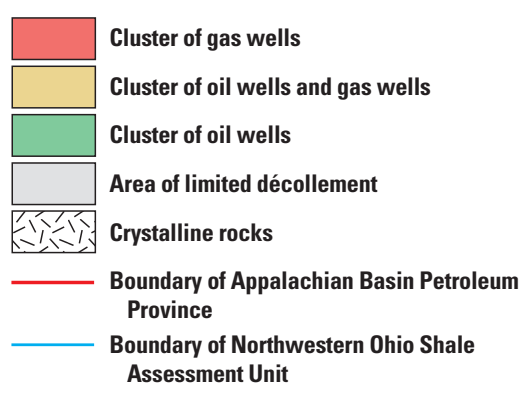

EXPLANATION

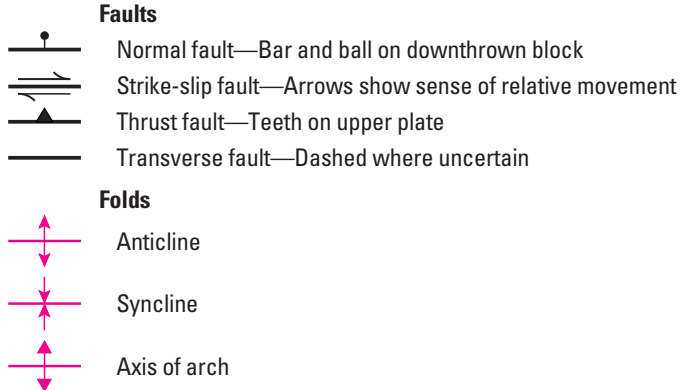


Figure 27 (facing page). Map showing the relation of the Northwestern Ohio Shale Assessment Unit to geologic structure. Structural geology is adapted from Ryder and others (2008). Décollement data are from Colton (1970), Frey (1973), Patenaude and others (1986), and Sanford (1993). 


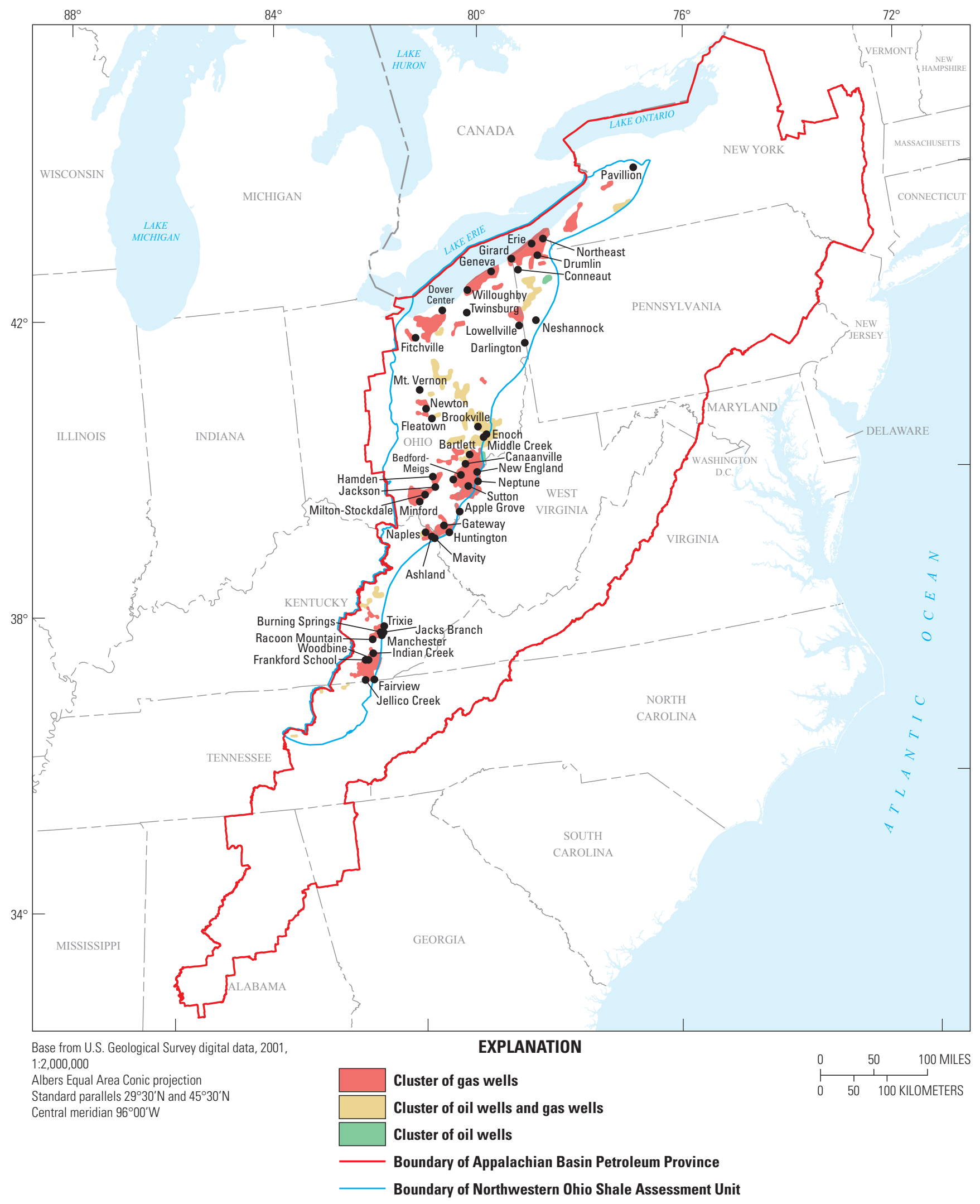

- Named gas field

Figure 28. Map showing named fields in the Northwestern Ohio Shale Assessment Unit (data from Roen and Walker, 1996). 







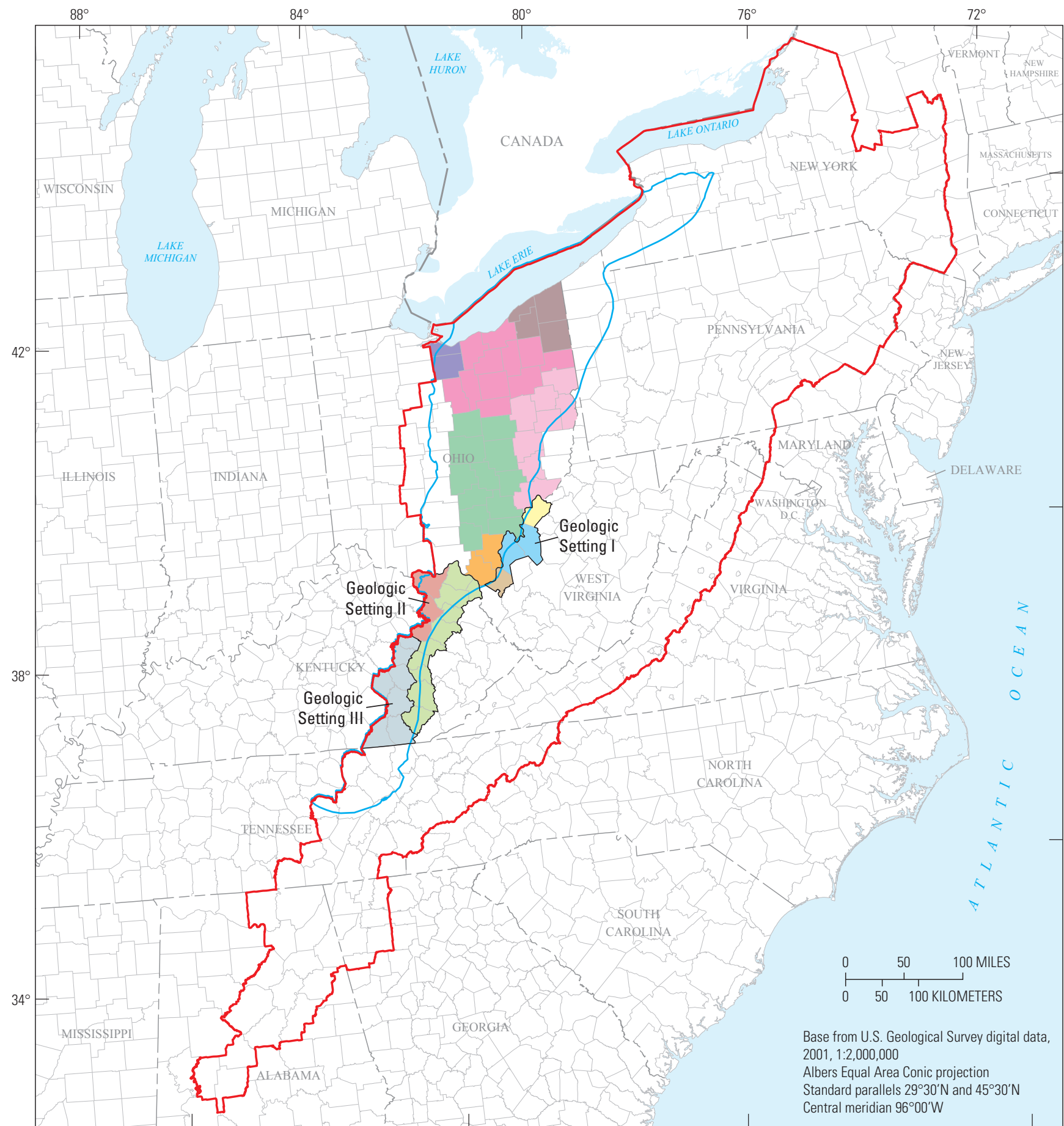

EXPLANATION

Geological Setting I (areas of known production) in West Virginia according to Kuuskraa and others (1985)

Area I

Area IV

Area VI

Geological Setting II (areas of limited production) in Kentucky according to Kuuskraa and others (1985) Shallow target

Medium target

Geological Setting III (areas of speculative production) in Kentucky according to Kuuskraa and others (1985)








Figure 31. Graph showing the distribution of estimated ultimate recovery (EUR) values per well for wells in the Northwestern Ohio Shale Assessment Unit (Troy Cook, U.S. Geological Survey, unpub. data, 2002; using data from Roen and Walker, 1996). The EUR data were sorted according to date and then partitioned chronologically into three groups, each of which had the same number of data. Separate graphs are shown for the early third, middle third, and late third of EUR values.

Figure 30 (facing page). Map showing the geological settings and partitioned areas of Kuuskraa and others (1985) in the Northwestern Ohio Shale Assessment Unit. 


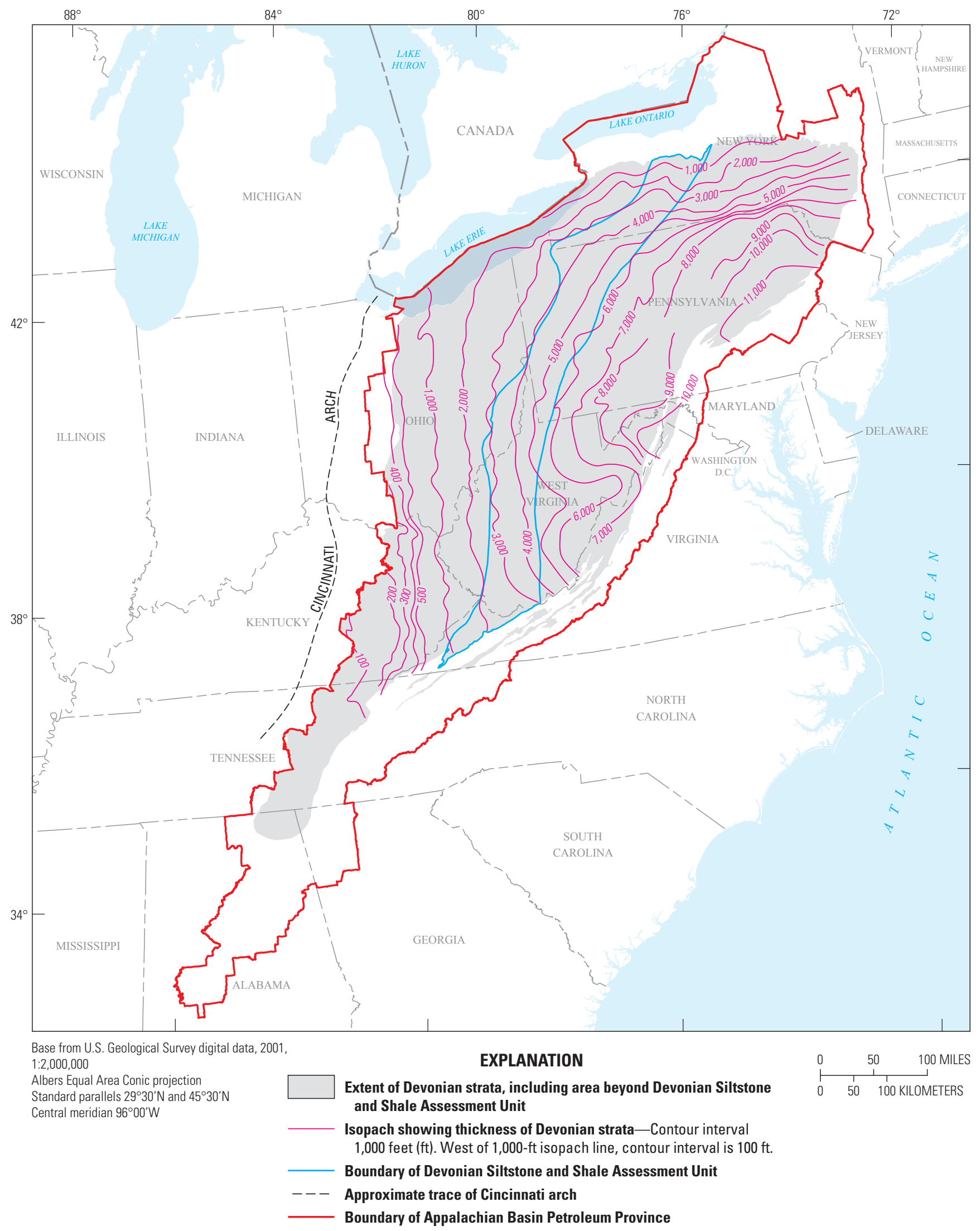


Figure 32 (facing page). Map showing the extent and thickness of Devonian strata in the Appalachian Basin Petroleum Province and the Devonian Siltstone and Shale Assessment Unit (adapted from de Witt and others, 1975). 


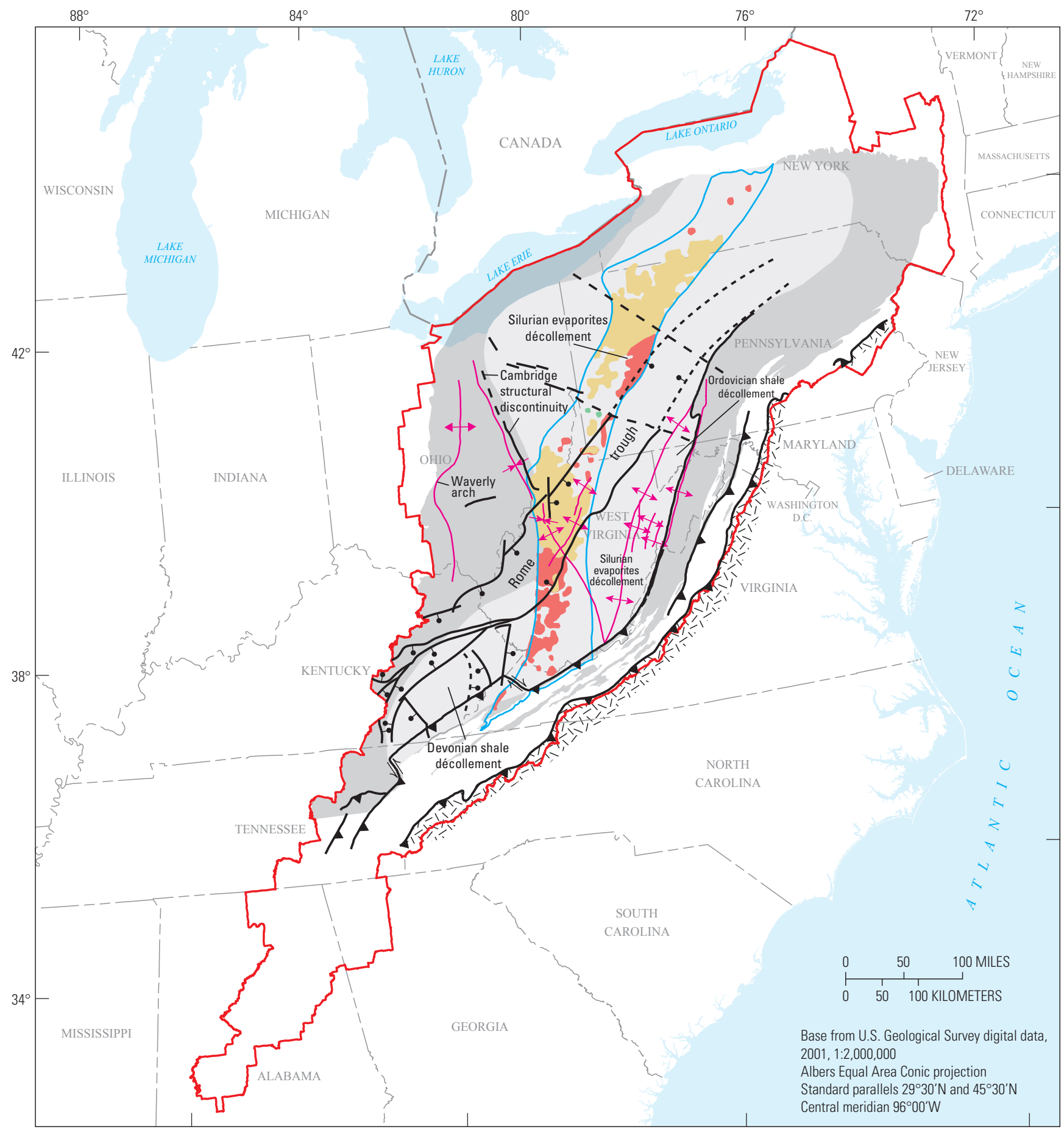

\section{EXPLANATION}

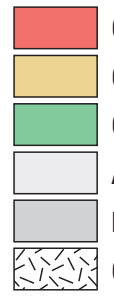

Cluster of gas wells

Cluster of oil wells and gas wells

Cluster of oil wells

Area of limited décollement

Extent of Devonian shale beyond area of limited décollement

Crystalline rocks

Boundary of Appalachian Basin Petroleum Province Boundary of Devonian Siltstone and Shale Assessment Unit

\section{Faults}

- Normal fault-Bar and ball on downthrown block

$\rightleftharpoons$ Strike-slip fault-Arrows show sense of relative movement

_ـ Thrust fault-Teeth on upper plate

_ Transverse fault-Dashed where uncertain Folds

Anticline

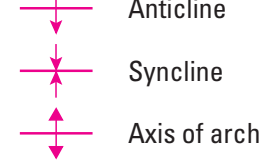


Figure 33 (facing page). Map showing relation of the Devonian Siltstone and Shale Assessment Unit to geologic structure. Structural geology is adapted from Ryder and others (2008). Décollement data are from Colton (1970), Frey (1973), Patenaude and others (1986), and Sanford (1993). 




Figure 34. Map showing locations of named fields in the Devonian Siltstone and Shale Assessment Unit and the Marcellus Shale Assessment Unit (data from Roen and Walker, 1996). 


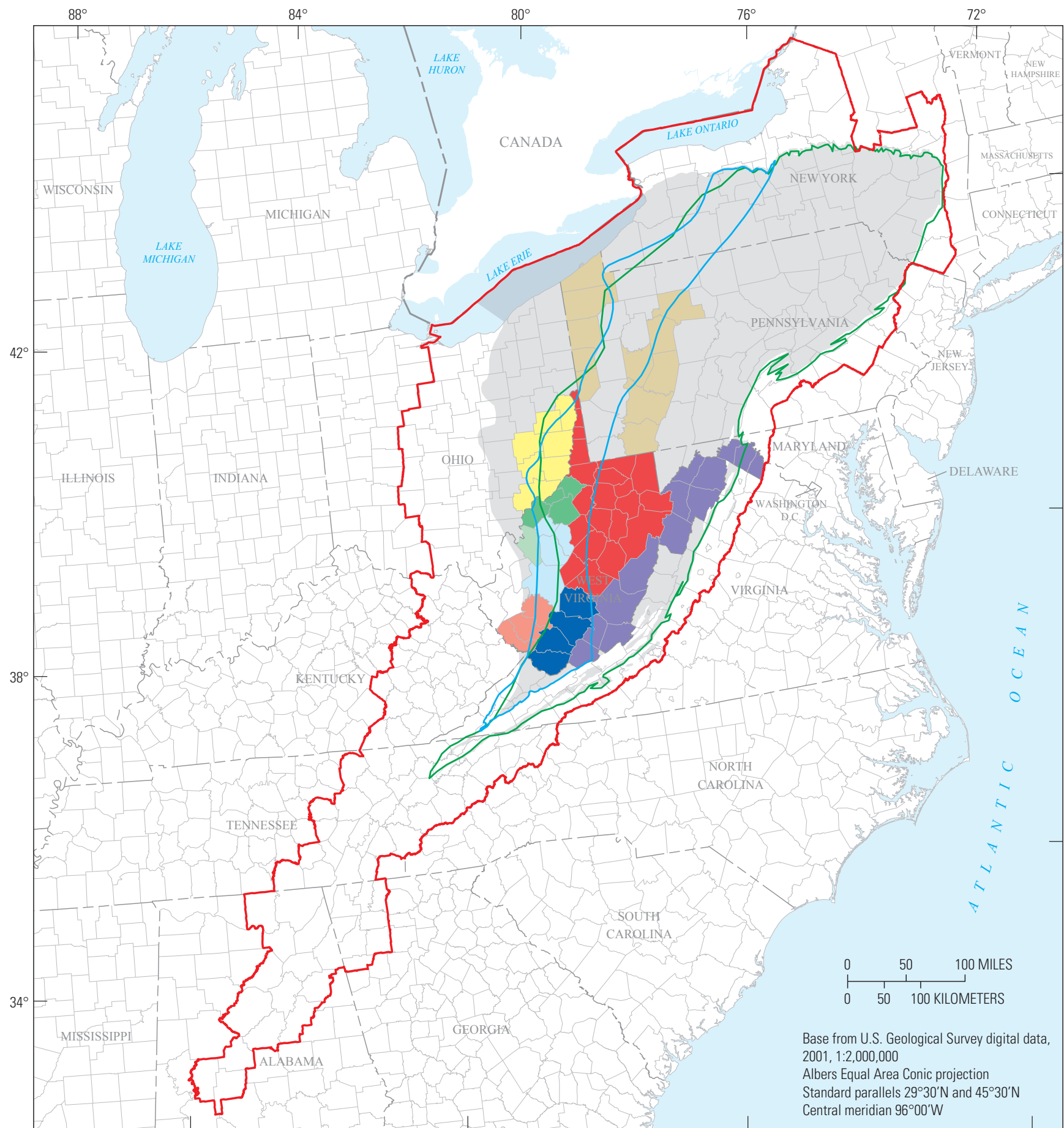

\section{EXPLANATION}

Extent of Devonian Shale - Includes areas beyond boundary of Devonian Siltstone and Shale Assessment Unit and Marcellus Shale Assessment Unit

Area in Pennsylvania with estimated favorable gas-in-place (GIP) resource potential between 482 and 790 trillion cubic feet

Boundary of Appalachian Basin Petroleum Province

Boundary of Devonian Siltstone and Shale Assessment Unit

Boundary of Marcellus Shale Assessment Unit
Non-USGS estimates of gas-in-place (GIP) resources for the Huron Member of the Ohio Shale, Rhinestreet Shale Member of the West Falls Formation, and Marcellus Shale-In billions of cubic feet. Compiled from Tetra Tech (1981), Lewin and Associates (1983), Kuuskraa and Wicks (1984), and Kuuskraa and others (1985).

1.53

3.53
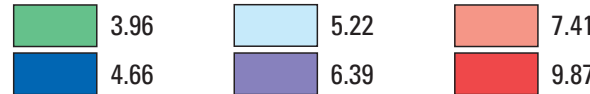

Figure 35. Map showing estimated gas-in-place (GIP) resources for the Huron Member of the Ohio Shale, the Rhinestreet Shale Member of the West Falls Formation, and the Marcellus Shale (data from Tetra Tech, 1981; Lewin and Associates, 1983; Kuuskraa and Wicks, 1984; Kuuskraa and others, 1985). 


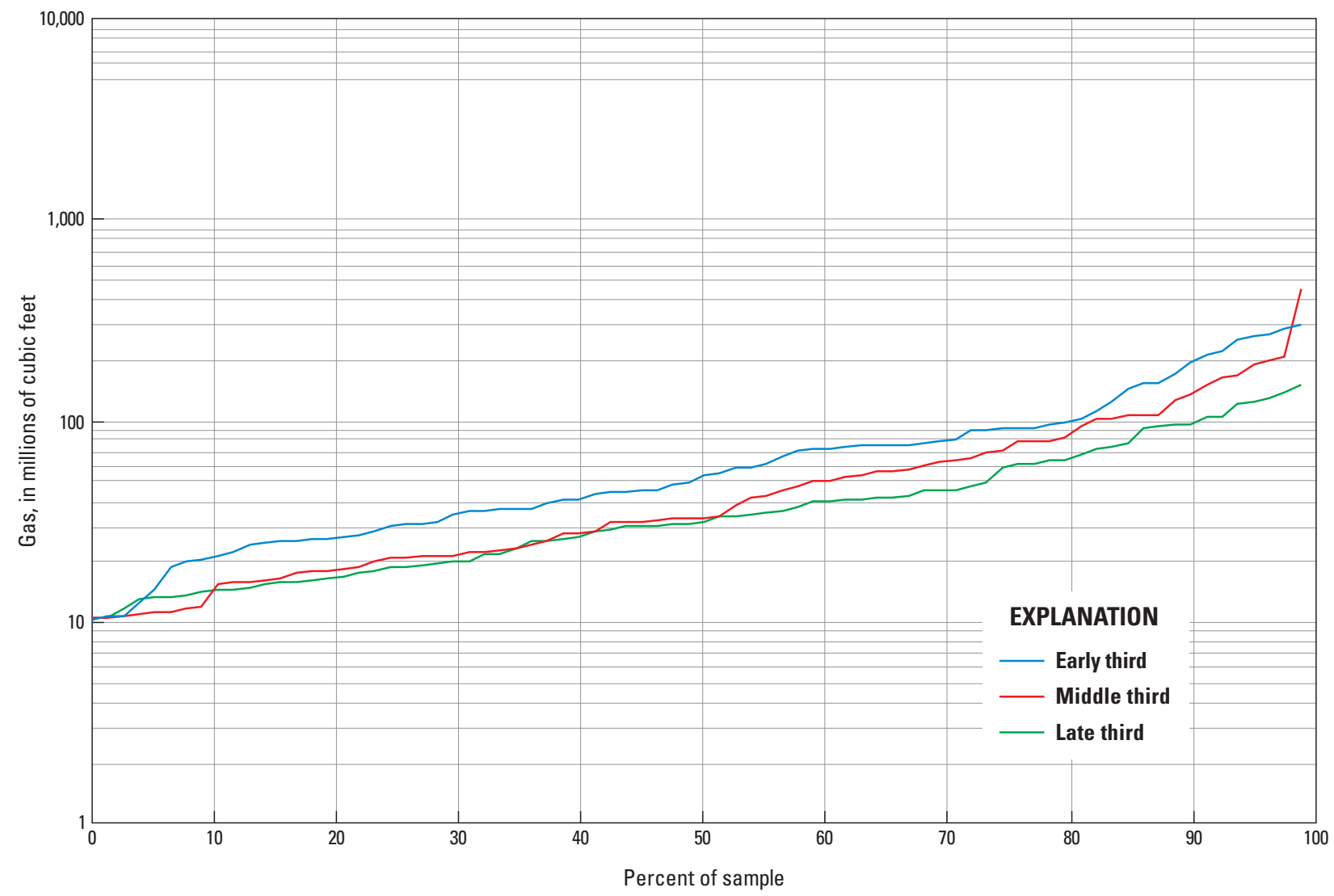

Figure 36. Graph showing the distribution of estimated ultimate recovery (EUR) values per well for wells for the Devonian Siltstone and Shale Assessment Unit (Troy Cook, U.S. Geological Survey, unpub. data, 2002; using data from Roen and Walker, 1996). The EUR data were sorted according to date and then partitioned chronologically into three groups, each of which had the same number of data. Separate graphs are shown for the early third, middle third, and late third of EUR values. 


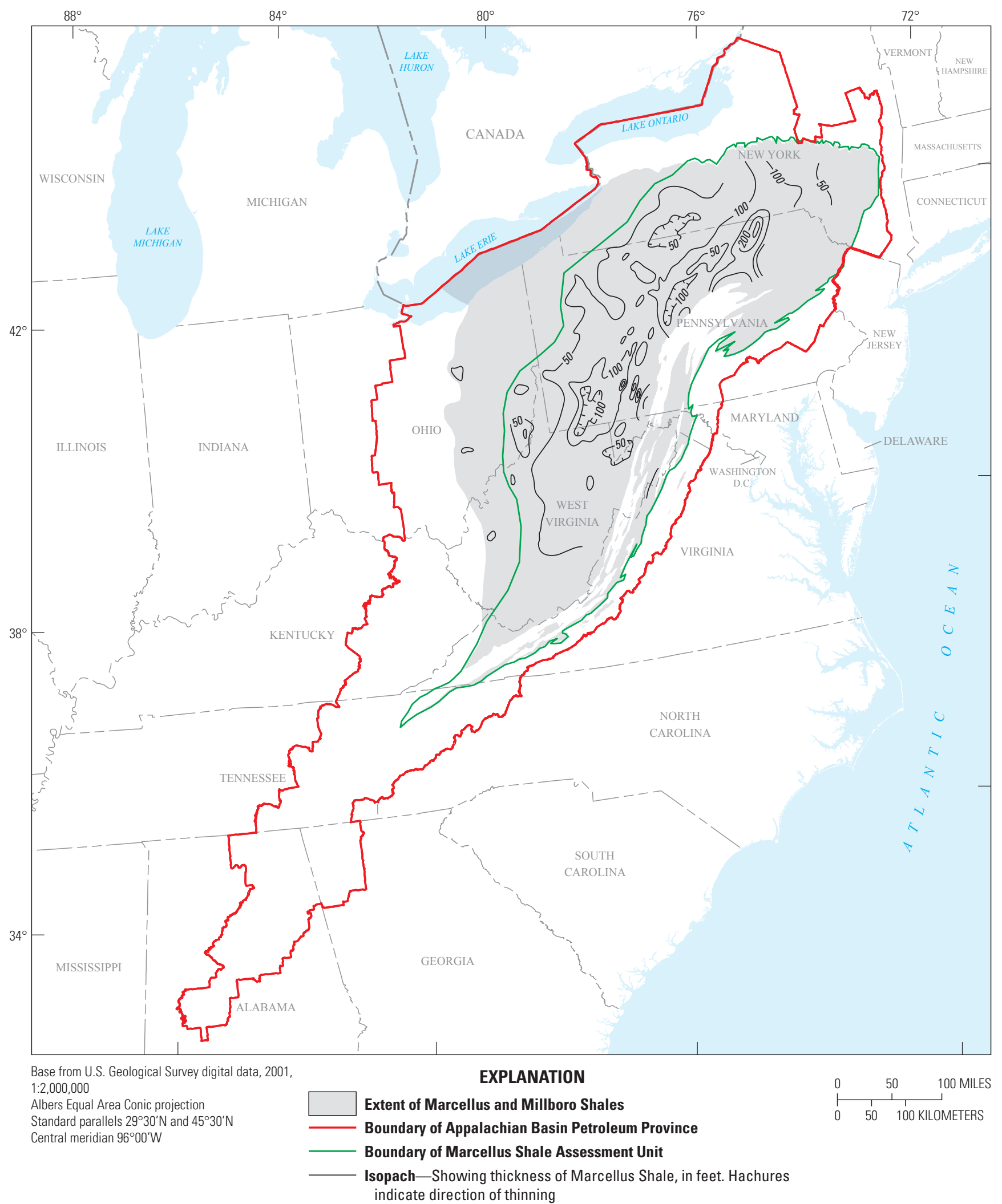

Figure 37. Isopach map of the Marcellus Shale (modified from de Witt and others, 1993). Note that the extent of the Marcellus Shale Assessment Unit, as used by the 2002 USGS assessment, is less than the total extent of the Marcellus Shale stratigraphic unit. The Marcellus Shale Assessment Unit includes the Millboro Shale in Virginia (see Milici and Swezey, 2006). 
Table 1. Characterization of assessment units for the U.S. Geological Survey 2002 assessment of undiscovered oil and gas resources in the Appalachian Basin Petroleum Province (summarized by Milici and others, 2003).

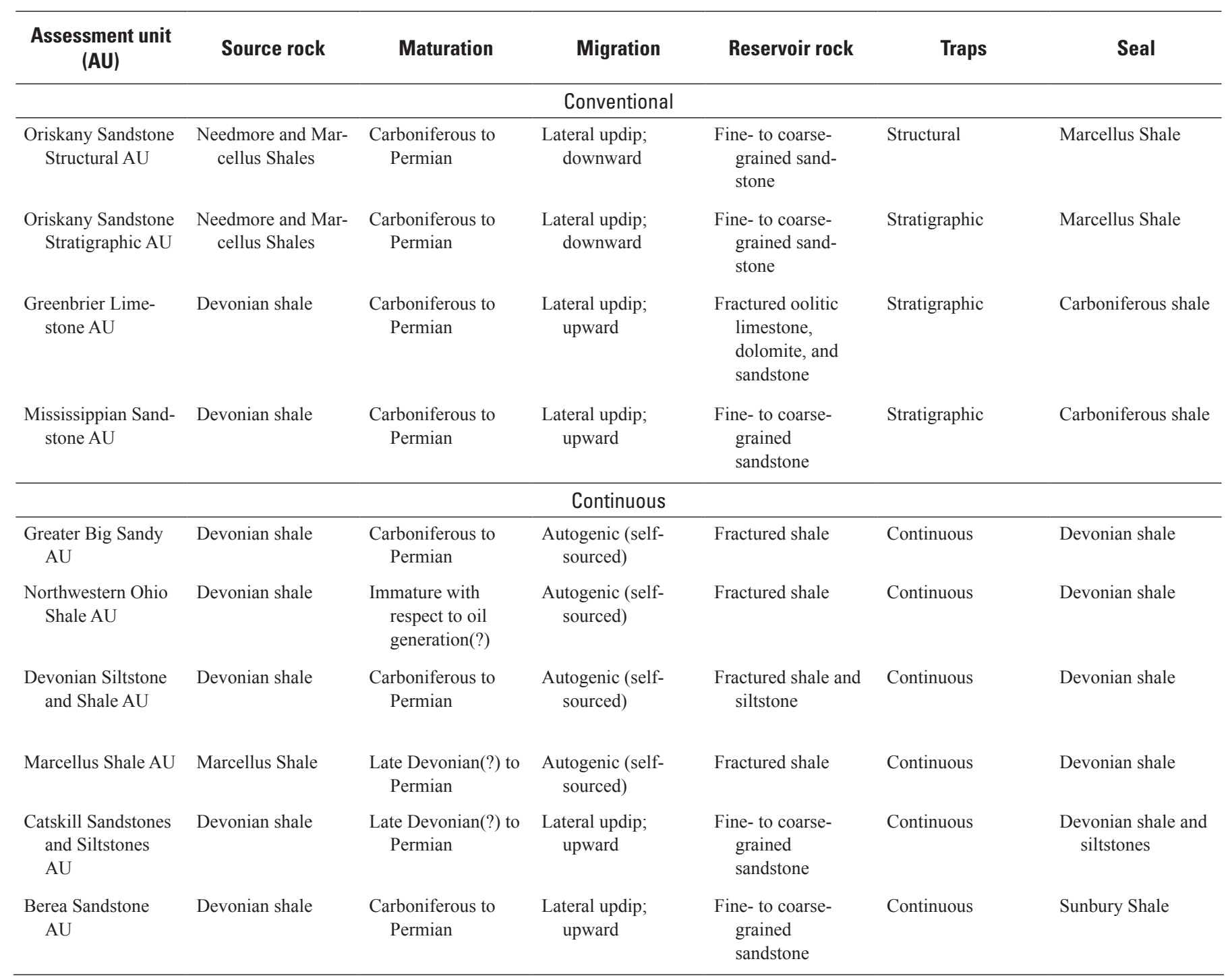


Table 2. Estimates of gas-in-place (GIP) resources in plays identified in figure 19 from Charpentier and others (1993), as allocated to the Devonian shale assessment units in the Appalachian Basin Petroleum Province.

[F95 denotes the 95th fractile; the probability of more than the amount F95 is 95 percent. F5 is defined similarly. Because of the dependency between plays, these fractiles (unlike those in many other studies) are additive. Dashes, - , denote areas where the plays as identified by Charpentier and others (1993) are not present in the assessment units as identified by Milici and others (2003). AU, Assessment Unit; TCF, trillion cubic feet]

\begin{tabular}{|c|c|c|c|c|c|c|c|c|c|c|c|}
\hline \multirow{3}{*}{ Play number and name } & \multicolumn{3}{|c|}{$\begin{array}{l}\text { Natural gas resources } \\
\text { (TCF) }\end{array}$} & \multicolumn{8}{|c|}{$\begin{array}{l}\text { Allocation of natural gas-in-place resources, by assessment unit } \\
\text { (in percent of mean and by amount) }\end{array}$} \\
\hline & \multirow{2}{*}{$\begin{array}{l}\text { Low } \\
\text { (F95) }\end{array}$} & \multirow{2}{*}{$\begin{array}{l}\text { High } \\
\text { (F5) }\end{array}$} & \multirow[b]{2}{*}{ Mean } & \multicolumn{2}{|c|}{$\begin{array}{l}\text { Greater Big Sandy } \\
\text { AU }\end{array}$} & \multicolumn{2}{|c|}{$\begin{array}{l}\text { Northwestern Ohio } \\
\text { Shale AU }\end{array}$} & \multicolumn{2}{|c|}{$\begin{array}{l}\text { Devonian Siltstone } \\
\text { and Shale AU }\end{array}$} & \multicolumn{2}{|c|}{$\begin{array}{l}\text { Marcellus Shale } \\
\text { AU }\end{array}$} \\
\hline & & & & $\begin{array}{l}\text { Percent } \\
\text { of mean } \\
\text { in play }\end{array}$ & $\begin{array}{l}\text { Gas-in- } \\
\text { place } \\
\text { (TCF) }\end{array}$ & $\begin{array}{c}\text { Percent } \\
\text { of mean } \\
\text { in play }\end{array}$ & $\begin{array}{l}\text { Gas-in- } \\
\text { place } \\
\text { (TCF) }\end{array}$ & $\begin{array}{l}\text { Percent } \\
\text { of mean } \\
\text { in play }\end{array}$ & $\begin{array}{l}\text { Gas-in- } \\
\text { place } \\
\text { (TCF) }\end{array}$ & $\begin{array}{l}\text { Percent } \\
\text { of mean } \\
\text { in play }\end{array}$ & $\begin{array}{c}\text { Gas-in- } \\
\text { place } \\
\text { (TCF) }\end{array}$ \\
\hline 1-North-Central Ohio & 17.9 & 34.2 & 25.9 & - & - & 100 & 25.90 & - & - & - & - \\
\hline 2-Western Lake Erie & 21.7 & 31.3 & 26.5 & - & - & 100 & 26.50 & - & - & - & - \\
\hline 3-Eastern Lake Erie & 2.1 & 3.3 & 2.7 & - & - & 100 & 2.70 & - & - & - & - \\
\hline 4-Plateau Ohio & 44.4 & 76.2 & 59.9 & - & - & 100 & 59.90 & - & - & - & - \\
\hline 5-Eastern Ohio & 35.2 & 55.1 & 44.7 & - & - & 100 & 44.70 & - & - & - & - \\
\hline 6-Western Penn-York & 20.4 & 28.2 & 24.3 & - & - & 50 & 12.15 & 50 & 12.15 & - & - \\
\hline $\begin{array}{l}\text { 7-Southern Ohio } \\
\text { Valley }\end{array}$ & 19.7 & 36.2 & 27.7 & 10 & 2.77 & 90 & 24.93 & - & - & - & - \\
\hline $\begin{array}{l}8 \text { - Western Rome } \\
\text { trough }\end{array}$ & 38.0 & 74.0 & 56.0 & 80 & 44.80 & 20 & 11.20 & - & - & - & - \\
\hline 9-Tug Fork & 13.7 & 25.9 & 19.7 & 65 & 12.81 & - & - & 35 & 6.90 & - & - \\
\hline 10-Pine Mountain & 10.7 & 18.7 & 14.6 & 100 & 14.60 & - & - & - & - & - & - \\
\hline 11_Plateau Virginia & 3.9 & 10.2 & 7.1 & 20 & 1.42 & - & - & 80 & 5.68 & - & - \\
\hline 12-Pittsburgh Basin & 76.8 & 129.9 & 102.1 & - & - & 30 & 30.63 & 55 & 56.16 & 15 & 15.32 \\
\hline $\begin{array}{l}\text { 13-Eastern Rome } \\
\text { Trough }\end{array}$ & 70.7 & 132.5 & 100.3 & - & - & - & 0.00 & 40 & 40.12 & 60 & 60.18 \\
\hline 14-New River & 38.5 & 91.7 & 63.1 & - & - & - & 0.00 & 40 & 25.24 & 60 & 37.86 \\
\hline 15-Portage Escarpment & 8.5 & 21.3 & 14.6 & - & - & 20 & 2.92 & 70 & 10.22 & 10 & 1.46 \\
\hline 16-Cattaraugus Valley & 10.4 & 23.2 & 16.6 & - & - & 20 & 3.32 & 80 & 13.28 & - & 0.00 \\
\hline 17-Penn-York Plateau & 98.1 & 195.2 & 146.0 & - & - & - & - & 40 & 58.40 & 60 & 87.60 \\
\hline $\begin{array}{l}\text { 18-Western Susque- } \\
\text { hanna }\end{array}$ & 24.1 & 67.7 & 44.9 & - & - & - & - & - & - & 100 & 44.90 \\
\hline 19 -Catskill & 22.1 & 75.8 & 47.6 & - & - & - & - & - & - & 100 & 47.60 \\
\hline Total & 577.1 & $\overline{1,130.8}$ & 844.3 & & 76.40 & & 244.85 & & 228.14 & & 294.92 \\
\hline
\end{tabular}


Table 3. Devonian shale geochemistry data from the Appalachian Basin Petroleum Province (compiled from Streib, 1981).

[EGSP, Eastern Gas Shales Project of the U.S. Department of Energy (2007); n.d., no data]

\begin{tabular}{|c|c|c|c|c|c|c|c|c|c|}
\hline State & County & $\begin{array}{c}\text { EGSP } \\
\text { well } \\
\text { number }\end{array}$ & Stratigraphic unit & $\begin{array}{l}\text { Depth } \\
\text { (feet) }\end{array}$ & $\begin{array}{c}\text { Thickness } \\
\text { (feet) }\end{array}$ & $\begin{array}{l}\text { Gas volume } \\
\text { (cubic feet) }\end{array}$ & $\begin{array}{c}\text { Total } \\
\text { carbon } \\
\text { (percent) }\end{array}$ & $\begin{array}{c}\text { Total } \\
\text { organic } \\
\text { carbon } \\
\text { (percent) }\end{array}$ & $\begin{array}{c}\text { Mean } \\
\text { vitrinite } \\
\text { reflectance } \\
\text { (percent) }\end{array}$ \\
\hline \multicolumn{10}{|c|}{ Greater Big Sandy Assessment Unit } \\
\hline Kentucky & Johnson & KY\#4 & $\begin{array}{c}\text { Cleveland Member } \\
\text { of Ohio Shale }\end{array}$ & 1,002 & 93 & 0.69 & 3.61 & 3.83 & 0.52 \\
\hline Kentucky & Johnson & KY\#4 & $\begin{array}{l}\text { Lower part of Huron } \\
\text { Member of Ohio } \\
\text { Shale }\end{array}$ & 1,304 & 119 & 0.60 & 6.03 & 4.84 & 0.58 \\
\hline Kentucky & Johnson & KY\#4 & $\begin{array}{l}\text { Middle part of } \\
\text { Huron Member of } \\
\text { Ohio Shale }\end{array}$ & 1,188 & 116 & 0.69 & 4.42 & 2.52 & 0.55 \\
\hline Kentucky & Martin & KY\#3 & $\begin{array}{l}\text { Cleveland Member } \\
\text { of Ohio Shale }\end{array}$ & 2,432 & 80 & 0.56 & 5.66 & 3.58 & 0.53 \\
\hline Kentucky & Martin & KY\#3 & $\begin{array}{l}\text { Lower part of Huron } \\
\text { Member of Ohio } \\
\text { Shale }\end{array}$ & 2,910 & 218 & 0.55 & 3.90 & 2.88 & 0.46 \\
\hline Kentucky & Martin & KY\#3 & $\begin{array}{l}\text { Rhinestreet Shale } \\
\text { Member of West } \\
\text { Falls Formation }\end{array}$ & 3,360 & 60 & 0.43 & 3.79 & 1.64 & 0.49 \\
\hline Kentucky & Perry & KY\#1 & $\begin{array}{l}\text { Huron Member (un- } \\
\text { divided) of Ohio } \\
\text { Shale }\end{array}$ & 2,455 & 213 & n.d. & 3.77 & 3.53 & n.d. \\
\hline Kentucky & Perry & KY\#1 & $\begin{array}{l}\text { Rhinestreet Shale } \\
\text { Member of West } \\
\text { Falls Formation }\end{array}$ & 2,686 & 22 & n.d. & 2.17 & 1.34 & n.d. \\
\hline Virginia & Wise & VA\#1 & $\begin{array}{c}\text { Cleveland Member } \\
\text { of Ohio Shale }\end{array}$ & 4,870 & 68 & 1.41 & 4.55 & 4.35 & 0.97 \\
\hline Virginia & Wise & VA\#1 & $\begin{array}{l}\text { Lower part of Huron } \\
\text { Member of Ohio } \\
\text { Shale* }\end{array}$ & 5,330 & 50 & 1.20 & 3.24 & 3.40 & 1.01 \\
\hline Virginia & Wise & VA\#1 & $\begin{array}{l}\text { Rhinestreet Shale } \\
\text { Member of West } \\
\text { Falls Formation }\end{array}$ & 6,530 & 48 & n.d. & n.d. & n.d. & n.d. \\
\hline
\end{tabular}


Table 3. Devonian shale geochemistry data from the Appalachian Basin Petroleum Province (compiled from Streib, 1981).-Continued [EGSP, Eastern Gas Shales Project of the U.S. Department of Energy (2007); n.d., no data]

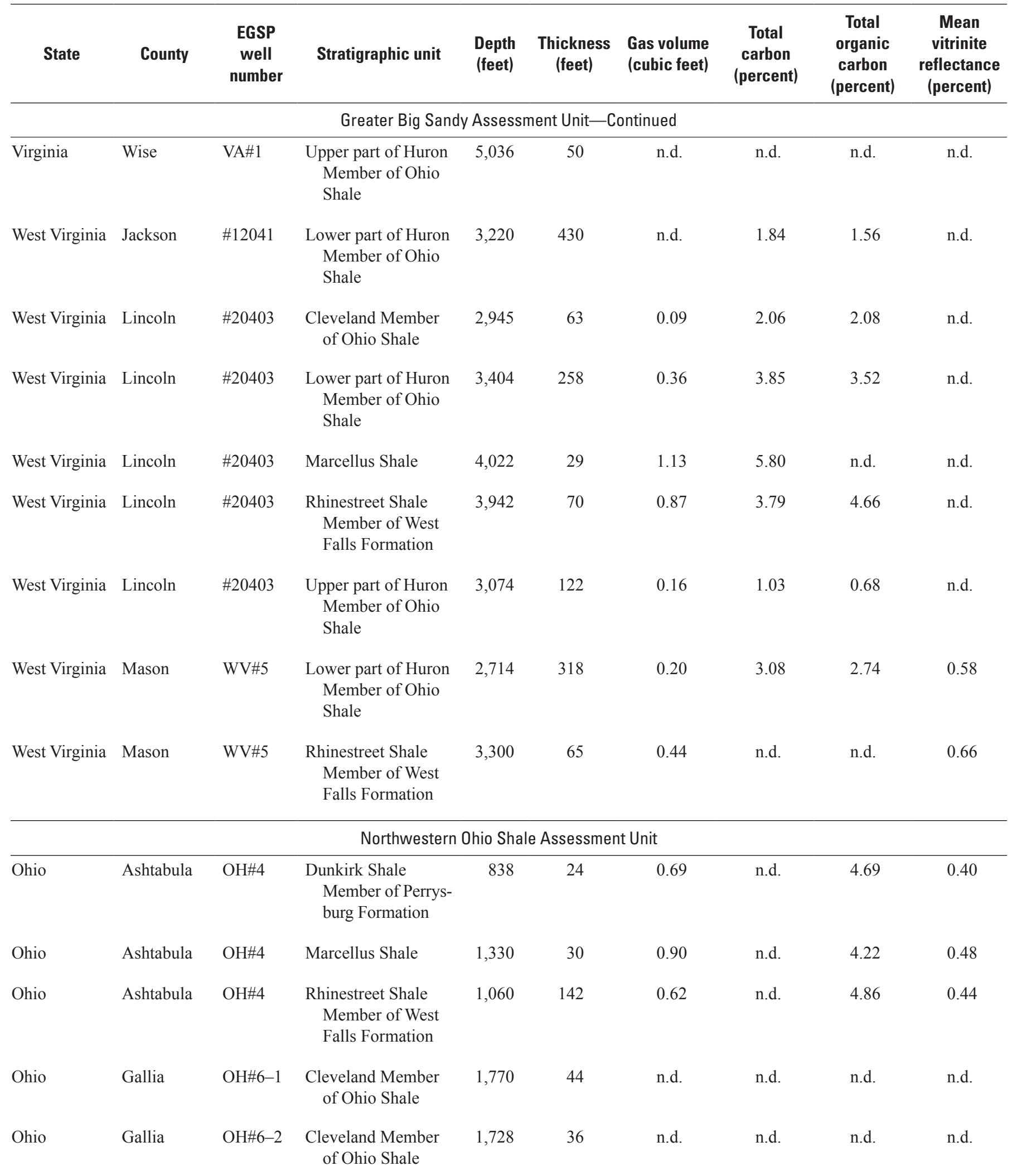


Table 3. Devonian shale geochemistry data from the Appalachian Basin Petroleum Province (compiled from Streib, 1981)._-Continued [EGSP, Eastern Gas Shales Project of the U.S. Department of Energy (2007); n.d., no data]

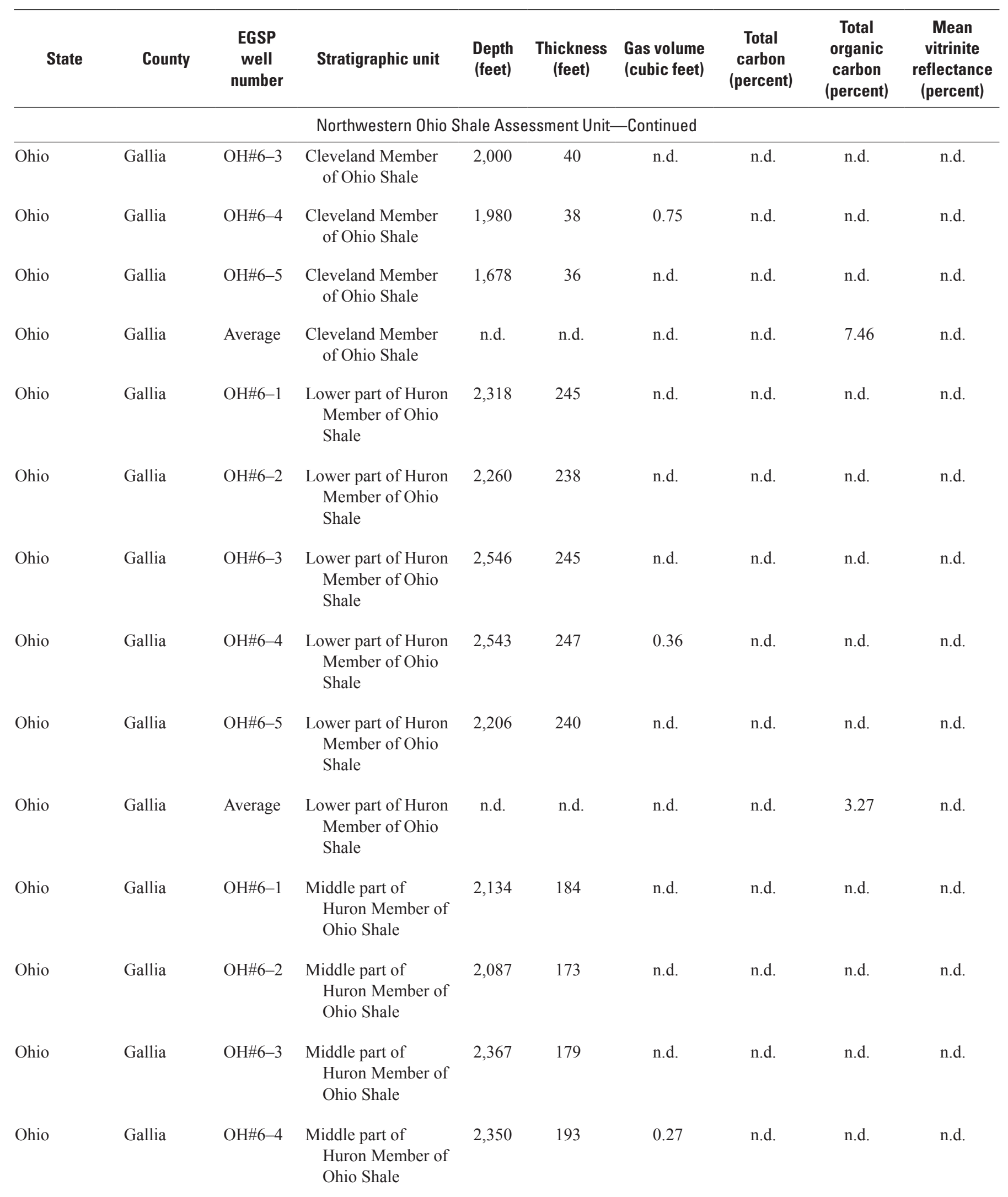


Table 3. Devonian shale geochemistry data from the Appalachian Basin Petroleum Province (compiled from Streib, 1981).—Continued [EGSP, Eastern Gas Shales Project of the U.S. Department of Energy (2007); n.d., no data]

\begin{tabular}{|c|c|c|c|c|c|c|c|c|c|}
\hline State & County & $\begin{array}{c}\text { EGSP } \\
\text { well } \\
\text { number }\end{array}$ & Stratigraphic unit & $\begin{array}{l}\text { Depth } \\
\text { (feet) }\end{array}$ & $\begin{array}{l}\text { Thickness } \\
\text { (feet) }\end{array}$ & $\begin{array}{l}\text { Gas volume } \\
\text { (cubic feet) }\end{array}$ & $\begin{array}{c}\text { Total } \\
\text { carbon } \\
\text { (percent) }\end{array}$ & $\begin{array}{l}\text { Total } \\
\text { organic } \\
\text { carbon } \\
\text { (percent) }\end{array}$ & $\begin{array}{c}\text { Mean } \\
\text { vitrinite } \\
\text { reflectance } \\
\text { (percent) }\end{array}$ \\
\hline \multicolumn{10}{|c|}{ Northwestern Ohio Shale Assessment Unit-Continued } \\
\hline Ohio & Gallia & $\mathrm{OH} \# 6-5$ & $\begin{array}{l}\text { Middle part of } \\
\text { Huron Member of } \\
\text { Ohio Shale }\end{array}$ & 2,034 & 172 & n.d. & n.d. & n.d. & n.d. \\
\hline Ohio & Gallia & Average & $\begin{array}{l}\text { Middle part of } \\
\text { Huron Member of } \\
\text { Ohio Shale }\end{array}$ & n.d. & n.d. & n.d. & n.d. & n.d. & n.d. \\
\hline Ohio & Gallia & $\mathrm{OH} \# 6-1$ & $\begin{array}{l}\text { Upper part of Huron } \\
\text { Member of Ohio } \\
\text { Shale }\end{array}$ & 2,007 & 127 & n.d. & n.d. & n.d. & n.d. \\
\hline Ohio & Gallia & $\mathrm{OH} \# 6-3$ & $\begin{array}{l}\text { Upper part of Huron } \\
\text { Member of Ohio } \\
\text { Shale }\end{array}$ & 2,224 & 143 & n.d. & n.d. & n.d. & n.d. \\
\hline Ohio & Gallia & $\mathrm{OH} \# 6-4$ & $\begin{array}{l}\text { Upper part of Huron } \\
\text { Member of Ohio } \\
\text { Shale }\end{array}$ & 2,200 & 150 & 0.56 & n.d. & n.d. & n.d. \\
\hline Ohio & Gallia & $\mathrm{OH} \# 6-5$ & $\begin{array}{l}\text { Upper part of Huron } \\
\text { Member of Ohio } \\
\text { Shale }\end{array}$ & 1,900 & 134 & n.d. & n.d. & n.d. & n.d. \\
\hline Ohio & Knox & $\mathrm{OH} \# 3$ & $\begin{array}{c}\text { Cleveland Member } \\
\text { of Ohio Shale }\end{array}$ & 579 & 33 & 0.77 & 11.30 & 5.43 & 0.51 \\
\hline Ohio & Knox & $\mathrm{OH} \# 3$ & $\begin{array}{l}\text { Huron Member (un- } \\
\text { divided) of Ohio } \\
\text { Shale }\end{array}$ & 712 & 442 & 0.45 & 4.24 & 2.84 & 0.56 \\
\hline Ohio & Lorain & $\mathrm{OH} \# 5$ & $\begin{array}{c}\text { Cleveland Member } \\
\text { of Ohio Shale }\end{array}$ & 299 & 129 & 0.30 & n.d. & 3.14 & n.d. \\
\hline Ohio & Lorain & $\mathrm{OH} \# 5$ & $\begin{array}{l}\text { Lower part of Huron } \\
\text { Member of Ohio } \\
\text { Shale }\end{array}$ & 901 & 187 & 0.95 & n.d. & 7.79 & n.d. \\
\hline Ohio & Lorain & $\mathrm{OH} \# 5$ & $\begin{array}{l}\text { Middle part of } \\
\text { Huron Member of } \\
\text { Ohio Shale }\end{array}$ & 814 & 87 & 0.99 & n.d. & 5.59 & n.d. \\
\hline
\end{tabular}


Table 3. Devonian shale geochemistry data from the Appalachian Basin Petroleum Province (compiled from Streib, 1981)._-Continued [EGSP, Eastern Gas Shales Project of the U.S. Department of Energy (2007); n.d., no data]

\begin{tabular}{|c|c|c|c|c|c|c|c|c|c|}
\hline State & County & $\begin{array}{c}\text { EGSP } \\
\text { well } \\
\text { number }\end{array}$ & Stratigraphic unit & $\begin{array}{l}\text { Depth } \\
\text { (feet) }\end{array}$ & $\begin{array}{l}\text { Thickness } \\
\text { (feet) }\end{array}$ & $\begin{array}{l}\text { Gas volume } \\
\text { (cubic feet) }\end{array}$ & $\begin{array}{c}\text { Total } \\
\text { carbon } \\
\text { (percent) }\end{array}$ & $\begin{array}{l}\text { Total } \\
\text { organic } \\
\text { carbon } \\
\text { (percent) }\end{array}$ & $\begin{array}{l}\text { Mean } \\
\text { vitrinite } \\
\text { reflectance } \\
\text { (percent) }\end{array}$ \\
\hline \multicolumn{10}{|c|}{ Northwestern Ohio Shale Assessment Unit-Continued } \\
\hline Ohio & Lorain & $\mathrm{OH} \# 5$ & $\begin{array}{l}\text { Upper part of Huron } \\
\text { Member of Ohio } \\
\text { Shale }\end{array}$ & 735 & 79 & 0.99 & n.d. & 4.38 & n.d. \\
\hline Ohio & Trumbull & $\mathrm{OH} \# 7$ & $\begin{array}{l}\text { Huron Member (un- } \\
\text { divided) of Ohio } \\
\text { Shale }\end{array}$ & 1,729 & 423 & 0.45 & n.d. & n.d. & n.d. \\
\hline Ohio & Trumbull & $\mathrm{OH} \# 7$ & Marcellus Shale & 2,672 & 36 & n.d. & n.d. & n.d. & n.d. \\
\hline Pennsylvania & Erie & PA\#3 & $\begin{array}{l}\text { Dunkirk Shale } \\
\text { Member of Perrys- } \\
\text { burg Formation }\end{array}$ & 375 & 262 & 0.10 & n.d. & 2.64 & 0.43 \\
\hline Pennsylvania & Erie & PA\#3 & Marcellus Shale & 1,218 & 30 & 0.25 & n.d. & 3.99 & 0.55 \\
\hline Pennsylvania & Erie & PA\#3 & $\begin{array}{l}\text { Rhinestreet Shale } \\
\text { Member of West } \\
\text { Falls Formation }\end{array}$ & 948 & 92 & 0.42 & n.d. & 4.97 & 0.49 \\
\hline
\end{tabular}

\begin{tabular}{|c|c|c|c|c|c|c|c|c|c|}
\hline \multicolumn{10}{|c|}{ Devonian Siltstone and Shale Assessment Unit } \\
\hline New York & Allegany & NY\#1 & $\begin{array}{l}\text { Dunkirk Shale } \\
\text { Member of Per- } \\
\text { rysburg Formation }\end{array}$ & 370 & 144 & 0.03 & 0.40 & 0.12 & 0.67 \\
\hline New York & Allegany & NY\#1 & $\begin{array}{l}\text { Rhinestreet Shale } \\
\text { Member of West } \\
\text { Falls Formation }\end{array}$ & 1,335 & 1011 & 0.24 & 0.61 & 0.34 & 1.32 \\
\hline Ohio & Washington & $\mathrm{OH} \# 2$ & $\begin{array}{l}\text { Lower part of Huron } \\
\text { Member of Ohio } \\
\text { Shale* }\end{array}$ & 3,160 & 570 & 0.50 & 2.35 & 1.92 & 0.58 \\
\hline Pennsylvania & Allegheny & PA\#2 & Marcellus Shale & 7,332 & 164 & 0.33 & 6.86 & 3.34 & 2.47 \\
\hline West Virginia & Wetzel & WV\#7 & $\begin{array}{l}\text { Rhinestreet Shale } \\
\text { Member of West } \\
\text { Falls Formation }\end{array}$ & 6,102 & 77 & 0.29 & 1.85 & 0.49 & 1.58 \\
\hline
\end{tabular}


Table 3. Devonian shale geochemistry data from the Appalachian Basin Petroleum Province (compiled from Streib, 1981).—Continued [EGSP, Eastern Gas Shales Project of the U.S. Department of Energy (2007); n.d., no data]

\begin{tabular}{|c|c|c|c|c|c|c|c|c|c|}
\hline State & County & $\begin{array}{c}\text { EGSP } \\
\text { well } \\
\text { number }\end{array}$ & Stratigraphic unit & $\begin{array}{l}\text { Depth } \\
\text { (feet) }\end{array}$ & $\begin{array}{l}\text { Thickness } \\
\text { (feet) }\end{array}$ & $\begin{array}{l}\text { Gas volume } \\
\text { (cubic feet) }\end{array}$ & $\begin{array}{c}\text { Total } \\
\text { carbon } \\
\text { (percent) }\end{array}$ & $\begin{array}{l}\text { Total } \\
\text { organic } \\
\text { carbon } \\
\text { (percent) }\end{array}$ & $\begin{array}{l}\text { Mean } \\
\text { vitrinite } \\
\text { reflectance } \\
\text { (percent) }\end{array}$ \\
\hline \multicolumn{10}{|c|}{ Marcellus Shale Assessment Unit } \\
\hline West Virginia & Monongalia & WV\#6 & Marcellus Shale & 7,396 & 104 & 0.38 & 6.79 & n.d. & 2.30 \\
\hline Tennessee & Grainger & TN\#9 & $\begin{array}{l}\text { Cleveland Member } \\
\text { of Ohio Shale }\end{array}$ & 1,134 & 102 & $<0.01$ & n.d. & 2.84 & n.d. \\
\hline Tennessee & Grainger & TN\#9 & $\begin{array}{l}\text { Lower part of Huron } \\
\text { Member of Ohio } \\
\text { Shale }\end{array}$ & 1,632 & 102 & 0.12 & n.d. & 3.73 & n.d. \\
\hline Tennessee & Grainger & TN\#9 & $\begin{array}{l}\text { Rhinestreet Shale } \\
\text { Member of West } \\
\text { Falls Formation }\end{array}$ & 1,834 & 22 & 0.33 & n.d. & 2.58 & n.d. \\
\hline Tennessee & Grainger & TN\#9 & $\begin{array}{l}\text { Upper part of Huron } \\
\text { Member of Ohio } \\
\text { Shale }\end{array}$ & 1,418 & 84 & n.d. & n.d. & n.d. & n.d. \\
\hline
\end{tabular}

*Different samples were analyzed for total organic carbon.

${ }^{* *}$ Cored interval is in the lower part of the Huron Member of the Ohio Shale from 3,491 to 3,711 feet. 
Table 4. Summary of total organic carbon (TOC) content of samples from the Devonian Marcellus Shale and the Rhinestreet Shale Member of the West Falls Formation (compiled from Weary and others, 2000; Repetski and others, 2002, 2005).

[DSS, Devonian Siltstone and Shale; GBS, Greater Big Sandy; MS, Marcellus Shale; NWOS, Northwestern Ohio Shale; - , no data]

\begin{tabular}{|c|c|c|c|c|c|c|c|c|c|c|c|}
\hline $\begin{array}{c}\text { Assessment } \\
\text { Unit }\end{array}$ & County & $\begin{array}{c}\text { Total } \\
\text { organic } \\
\text { carbon } \\
\text { (percent) }\end{array}$ & $\begin{array}{l}\text { Assessment } \\
\text { Unit }\end{array}$ & County & $\begin{array}{c}\text { Total } \\
\text { organic } \\
\text { carbon } \\
\text { (percent) }\end{array}$ & $\begin{array}{c}\text { Assessment } \\
\text { Unit }\end{array}$ & County & $\begin{array}{c}\text { Total } \\
\text { organic } \\
\text { carbon } \\
\text { (percent) }\end{array}$ & $\begin{array}{l}\text { Assessment } \\
\text { Unit }\end{array}$ & County & $\begin{array}{c}\text { Total } \\
\text { organic } \\
\text { carbon } \\
\text { (percent) }\end{array}$ \\
\hline DSS & Ontario & 1.77 & DSS & Marshall & 1.98 & DSS & Forest & 6.1 & DSS & Raleigh & 1.94 \\
\hline DSS/MS & Yates & 6.22 & DSS & Wyoming & 1.8 & DSS & Greene & 5.92 & DSS & Roane & 1.22 \\
\hline DSS/MS & Seneca & 1.72 & DSS & Fayette & 1.68 & DSS & Allegheny & 5.38 & DSS & Wirt & 1.09 \\
\hline DSS/MS & Steuben & 1.57 & DSS & Fayette & 1.61 & DSS & Armstrong & 5.26 & DSS & Ritchie & 0.87 \\
\hline $\begin{array}{l}\text { DSS/ } \\
\text { NWOS }\end{array}$ & Livingston & 6.24 & DSS & Raleigh & 0.72 & DSS & Clarion & 3.98 & DSS/GBS & Wood & 1.85 \\
\hline $\begin{array}{l}\text { DSS/ } \\
\text { NWOS }\end{array}$ & $\begin{array}{c}\text { Cattarau- } \\
\text { gus }\end{array}$ & 5.77 & DSS & Doddridge & 0.56 & DSS & Warren & 1.92 & DSS/GBS & Wood & 0.61 \\
\hline MS & Chemung & 6.98 & DSS/GBS & Boone & 1.75 & DSS & Butler & 0.79 & DSS/GBS & Kanawha & 0.47 \\
\hline MS & Schuyler & 5.77 & MS & Greenbrier & 1.95 & DSS/MS & $\begin{array}{l}\text { Washing- } \\
\text { ton }\end{array}$ & 3.35 & GBS & Cabell & 2.30 \\
\hline MS & Cayuga & 3.54 & MS & Tucker & 1.85 & DSS/MS & McKean & 2.86 & GBS & Jackson & 2.12 \\
\hline MS & Chenango & 2.19 & MS & Greenbrier & 1.74 & $\begin{array}{l}\text { DSS/ } \\
\text { NWOS }\end{array}$ & Venango & 4.6 & GBS & Wayne & 1.51 \\
\hline NWOS & Genesee & 5.7 & MS & Harrison & 0.47 & MS & Tioga & 4.68 & - & - & - \\
\hline NWOS & Erie & 4.86 & MS/DSS & Nicholas & 2.61 & MS & Clinton & 3.56 & - & - & - \\
\hline - & - & - & MS/DSS & Braxton & 1.69 & MS & Sullivan & 3.41 & - & - & - \\
\hline - & - & - & MS/DSS & Nicholas & 0.98 & MS & Bradford & 3.23 & - & - & - \\
\hline- & - & - & MS/DSS & Summers & 0.34 & MS & Clinton & 3.1 & - & - & - \\
\hline- & - & - & - & - & - & MS & Lycoming & 3.07 & - & - & - \\
\hline - & - & - & - & - & - & MS & Cambria & 3.03 & - & - & - \\
\hline
\end{tabular}


Table 4. Summary of total organic carbon (TOC) content of samples from the Devonian Marcellus Shale and the Rhinestreet Shale Member of the West Falls Formation (compiled from Weary and others, 2000; Repetski and others, 2002, 2005)._-Continued

[DSS, Devonian Siltstone and Shale; GBS, Greater Big Sandy; MS, Marcellus Shale; NWOS, Northwestern Ohio Shale; -, no data]

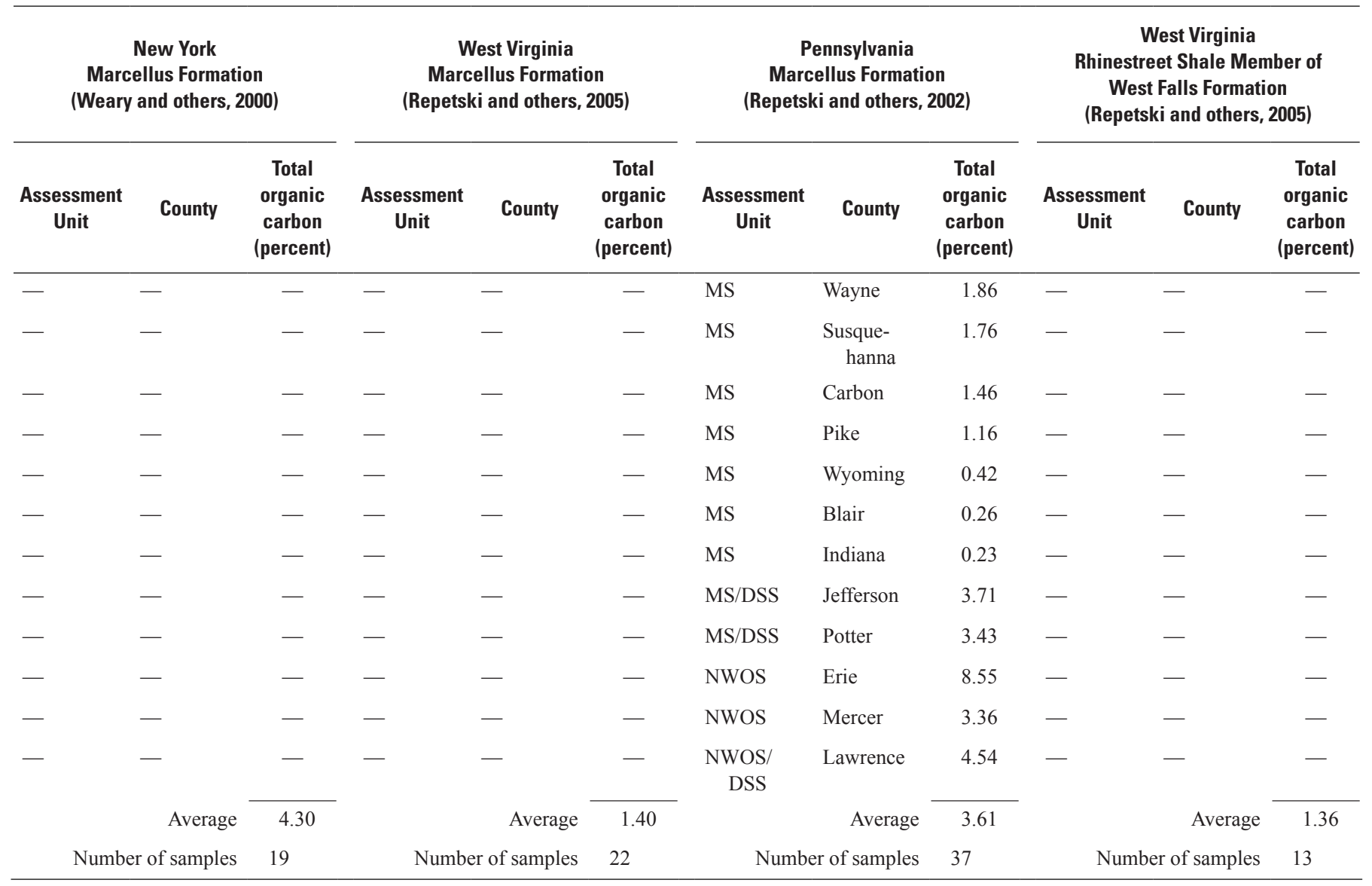

